\title{
CONCENTRAÇÃO DE FLÚOR EM \\ MEDICAMENTOS PEDIÁTRICOS E RISCO \\ DE FLUOROSE DENTÁRIA
}

\author{
ANDREA ANZAI
}

Dissertação apresentada à Faculdade de Odontologia de Bauru, da Universidade de São Paulo, como parte dos requisitos para obtenção do título de Mestre em Odontologia, Área de Odontopediatria.

(Edição Revisada) 


\title{
CONCENTRAÇÃO DE FLÚOR EM \\ MEDICAMENTOS PEDIÁTRICOS E RISCO \\ DE FLUOROSE DENTÁRIA
}

\author{
ANDREA ANZAI
}

Dissertação apresentada à Faculdade de Odontologia de Bauru, da Universidade de São Paulo, como parte dos requisitos para obtenção do título de Mestre em Odontologia, Área de Odontopediatria.

(Edição Revisada)

Orientadora: Profa. Dra. Salete Moura Bonifácio da Silva 
Anzai, Andrea

An98c

Concentração de flúor em medicamentos pediátricos e risco de fluorose dentária / Andrea Anzai - Bauru, 2003.

161p.: il.; $30,0 \mathrm{~cm}$

Dissertação. (Mestrado) - Faculdade de Odontologia de Bauru. USP.

Orientadora: Profa. Dra. Salete Moura Bonifácio da Silva

Autorizo, exclusivamente para fins acadêmicos e científicos, a reprodução total ou parcial desta dissertação, por processos fotocopiadores e outros meios eletrônicos.

Assinatura da autora:

Data: Bauru, 11 de abri de 2003. 


\title{
DADOS CURRICULARES
}

\author{
Andrea Anzai
}

Filiação

Nascimento

$1995-1998$

1999

$1999-2000$

$2001-2003$

Associações
Augusto Anzai

Ilene Yamacita Anzai

18 de abril de 1977

Presidente Prudente - SP

Curso de Graduação em Odontologia, Faculdade de Odontologia de Bauru - Universidade de São Paulo

Curso de Aperfeiçoamento em Odontopediatria FUNCRAF

Estágio na Disciplina de Odontopediatria da Faculdade de Odontologia de Presidente Prudente UNOESTE

Curso de Pós-Graduação em Odontopediatria, nível de Mestrado, Faculdade de Odontologia de Bauru Universidade de São Paulo

Conselho Regional de Odontologia do Estado de São Paulo - CRO - SP

Associação Paulista de Cirurgiões-Dentistas APCD

Associação dos Pós-Graduandos - APG - FOB / USP

Sociedade Brasileira de Pesquisa Odontológica $\mathrm{SBPqO}$ 
“... Em vez da monótona labuta

de procurar peixe junto dos barcos de pesca, temos uma razão para estar vivos!

Podemos subtrair-nos à ignorância, podemos encontrar-nos como criaturas excelentes, inteligentes e hábeis. Podemos ser livres! Podemos aprender a voar!"

\author{
Richard Bach \\ "Fernão Capelo Gaivota"
}




\section{DEDICATÓRIA}

“Vma nuvem não sabe

por que se move em tal

direção e em tal velocidade.

Sente o impulso... É para

este Lugar que devo ir agora. Mas o céu sabe

os motivos e desenhos

por trás de todas as nuvens.

E você também saberá,

quando se erguer o suficiente

para ver além

dos horizontes!"

Richard Bach

“... Direi do Senhor: Ele é o meu Deus, o meu refúgio, a minha fortaleza e, Nele confiarei ..."

Salmo 91

\section{À Deus,}

Pelo Seu eterno amor 
Aos meus pais Ilene e Augusto

\author{
"Como o arco que se curva o bastante para que
}

a flecha seja lançada, vocês confiaram em meus sonhos e fizeram o possívele o impossível para que cada um deles atingisse seu alvo e se tornasse a mais bela reafidade!

Minha Mãe,

Minha melhor amiga, que com compreensão, paciência, sabedoria e fé, me conduz no melhor caminho da vida, o do amor!

Meu Pai,

Meu amigo e mestre, que apesar de toda experiência, permite que eu trilhe o caminho da Odontologia com minhas próprias pernas, para que eu me torne uma pessoa melhor, realizada e forte. Meu maior exemplo de otimismo, entusiasmo e esperança!

Pelo amor e apoio constantes em todos os momentos da minha vida. 
"ONunca te és concedido um desejo sem que te sejas concedida também a faculdade de torná-lo realidade.

Entretanto, é possivel que tenhas que lutar por ele."

Richard Bach

Ao meu irmão Adilson e aos meus avós

\section{Aia Vatanabe Anzai e Sebastião Yamacita,}

pela compreensão nos momentos de ausência e, acima de tudo, por terem sempre me dado amor, carinho e condições de lutar. Por serem exemplos de vida e fontes de força, superação e estímulo, que renovam meu coração! 


\title{
À Profa. Dra. Salete Moura Bonifácio da Silva
}

"O exemplo é sempre mais eficaz que o preceito."

Samuel Johnson

"Do seu exemplo surgiu a vontade profunda, sincera, de buscar nada menos que o melhor. Da sua confiança nasceu a tranqüilidade, a felicidade de ver o sonho concretizado."

\begin{abstract}
A minha gratidão, admiração e respeito por tantos exemplos e ensinamentos que me proporcionou durante a nossa convivência... Pelas mãos seguras e por toda dedicação, paciência e carinho com que sempre me orientou... Pela confiança, oportunidade e apoio para a realização de cada um dos meus sonhos... Por ser uma pessoa iluminada e sábia, verdadeira amiga, com que o Senhor me abençoa... Por poder contar com você em minha vida! Uma amiga, mestre e orientadora única e muito especial!
\end{abstract}

Muito obrigada!!! E a vocês, dedico este trabalho. 


\section{AGRADECIMENTOS ESPECIAIS}

“Aos que passam pela nossa vida...

Cada um que passa em nossa vida, passa sozinho...

Porque cada pessoa é única e nenfuma substitui a outra.

Cada um que passa em nossa vida, passa sozinho, mas não vai só...

Nem nos deixa só,leva um pouco de nós mesmos e deixa um pouco de si mesmo.

Há os que levam muito, mas não há os que não levam nada.

Há os que deixam muito, mas não há os que não deixam nada.

Esta é a mais bela realidade da vida...

A prova evidente de que cada um é importante e que ninguém se aproxima do outro por acaso..."

Antonie de Saint-Exupéry

\section{À Profa. Dra. Marília Afonso Rabelo Buzalaf}

Pelo exemplo profissional e pessoal de que há espaço para tudo na vida, pela determinação, dedicação e competência científica, pela atenção e disponibilidade em transmitir seus conhecimentos, e pela inestimável contribuição para a realização deste trabalho. 
Ao Prof. Dr. José Mauro Granjeiro, pela solicitude e prontidão com que sempre me atendeu, apesar de seus compromissos; e por possibilitar a realização de pesquisas multicêntricas durante este curso.

À Thelma Lopes da Silva e à Tatiana de Almeida Furlani, minhas amigas e companheiras em todos os desafios, pela amizade, apoio, dedicação e disposição, que permitiram a realização deste trabalho.

À Pâmela, ao Ovídio e ao Gilmar, pela disposição em me ajudar e por me receber sempre com tanto carinho.

Ao Ricardo Ideny Rizzi pelo companheirismo e auxílio no início desta pesquisa.

Aos amigos do Laboratório de Bioquímica, especialmente à Vanessa Eid da Silva Cardoso, e também àqueles de passagem por lá, que compartilharam comigo suas vidas, suas pesquisas, ansiedades, dúvidas, aflições, dias e noites, sonhos, vontades, e o que mais importa, as alegrias de que deu certo, do resultado na mão, da conquista, do sonho realizado, do coração satisfeito, e da vontade de continuar.

\section{“Nenhuma história humana é escrita}

sem a presença de uma ou duas mãos amigas que se

estendem em nossa direção." 
Meu reconhecimento e minha gratidão a todos os profissionais que contribuíram para a realização desta pesquisa, através da doação de sua atenção, de seus conhecimentos e experiências, e de amostras-grátis de medicamentos:

Aos médicos Ademar Anzai, Ademir Anzai, Adriana Umemura, Adriano Anzai, Álisson Yoshiharu Umemura, Álvaro Anzai, Ana Eugênia Murari Perrone, Angela Honda, Angela Maria Ikeda Nórcia, Beatriz Clark Vicentini Otani, Caio César Bennatti (F.M.Presidente Prudente - UNOESTE), Celso Sakuma, Cláudio Antonio Rabello Coelho (F.M.Botucatu - UNESP), Christiane Hashimoto Hirata (F.M.Presidente Prudente - UNOESTE), Édson Mitsuo Idagawa, Lílian Mari Takigawa, Márcio Nakamura, Maria Célia Cervi (F.M.Ribeirão Preto - USP), Mitsuji Seki (F.M.Presidente Prudente - UNOESTE), Patrícia Martins Luizari (F.M.Presidente Prudente - UNOESTE), Rafael Wilson de Souza, Sílvia Saito, Telma Cristina de Freitas (UBAS - FOB / USP), e aos pediatras do Instituto da Criança de Presidente Prudente.

À Maria Cecília Botelho Bautz, enfermeira da Unidade Básica de Apoio ao SISUSP (UBAS), da Faculdade de Odontologia de Bauru, Universidade de São Paulo, sobretudo pela sua amizade, atenção e carinho desde minha graduação.

Ao Farmacêutico Ailton Hespanhol e às Sras. Janete Bazan Corral e Catarina Davina Bazan, da Associação Assistencial Adolpho Bezerra de Menezes, de Presidente Prudente. 
À Faculdade de Odontologia de Bauru, da Universidade de São Paulo, através de sua Diretora, Profa. Dra. Maria Fidela de Lima Navarro.

À Prefeitura do Campus Administrativo de Bauru, da Universidade de São Paulo, através de seu Prefeito, Prof. Dr. José Fernando Castanha Henriques.

À Comissão de Pós-Graduação da Faculdade de Odontologia de Bauru, da Universidade de São Paulo, através de seu Presidente, Prof. Dr. José Carlos Pereira.

Aos professores e funcionários da Faculdade de Odontologia de Bauru, Universidade de São Paulo, em especial aos professores do curso de PósGraduação e aos docentes da Disciplina de Odontopediatria, Dr. Aymar Pavarini, Dr. Bernardo Gonzalez Vono, Dr. José Eduardo de Oliveira Lima, Dra. Maria Aparecida de Andrade Moreira Machado, Dra. Maria Francisca Thereza Borro Bijella, Dr. Ruy César Camargo Abdo, Dra. Salete Moura Bonifácio da Silva e à Dra. Astrid Zaramella Vono, pela atenção e pelos ensinamentos a mim dispensados.

Às Profas. Dra. Maria Aparecida de Andrade Moreira Machado e Dra. Salete Moura Bonifácio da Silva, coordenadoras do curso de Mestrado em Odontopediatria durante os anos de 2001 e 2002-2003.

Às funcionárias e amigas da Disciplina de Odontopediatria, Fátima, D. Lia, Lílian, Maria Estela, e ainda à D. Wilma, Lidiane, Kelle, Cláudia e Amanda, pela atenção e carinho, em todos os momentos.

Ao Prof. Dr. Eduardo Batista Franco, responsável pelo início da minha vida acadêmica e científica, por estimular meu contínuo crescimento e desenvolvimento profissional e humano. Agradeço pela confiança em mim depositada, pela oportunidade de participar do Programa Especial de Treinamento PET- FOB / USP, uma experiência única, e pelo exemplo, competência e dedicação com que conduz seus alunos. 
Aos meus avós que já partiram, Isao Anzai e Yoachida Yamacita, por terem deixado a mim dois legados: um são as raízes, o outro são as asas, e também muitas alegrias e saudades.

Aos meus familiares, pelo amor que nos une e pelo estímulo constante que possibilitam alcançar meus objetivos.

Ao Laudo Teruaki Nakamura, pelo nosso verdadeiro AMOR e melhor felicidade.

À família Nakamura, por tanto carinho e por todos os momentos de alegria.

Ao AMIGO DANIEL ARAKI RIBEIRO, amigo e anjo com todas as letras maiúsculas, sempre presente em minha vida, com sua amizade sincera e alegre, disposto a buscar o melhor por mim.

À Sheila de Carvalho Stroppa, uma bênção em minha vida, pela amizade que nos une e por poder compartilhar com você tantos momentos felizes e tantas aflições. Não por acaso, você retornou à minha vida neste curso para ser minha parceira, para dar luz com sua sabedoria e amizade, para dar força com seu exemplo e sua determinação, para ensinar com o seu trabalho e sua competência, para andarmos juntas e podermos vencer.

À Flávia Bittencourt Pazinatto, pela amizade que cresce a cada dia, fortalecida pelo companheirismo, pela solidariedade, pela simplicidade e pelo apoio constante.

Às "meninas super-poderosas" Luciane Hirota, Cláudia Sanae Akita Shimoide e Mari Nishioka, pelo exemplo de amizade, alegria, paz e serenidade, que alentam a vida, muitas vezes atribulada.

À Tatiana de Almeida Furlani, Esther Rieko Takamori e Giovana Calicchio Canova, pelo carinho com que sempre me receberam, seja em seu 
apartamento ou no laboratório, e pela amizade inestimável, onde não existe o impossível.

À Sílvia Saito, Rosalyn Yuki Nebuya, Lílian Mari Takigawa e Marilen Missae Kawashima, nossa amizade atravessa o tempo e supera distâncias, sempre encontrando novas formas de se expressar e renovando a cumplicidade, a força e o apoio que damos umas às outras.

À Cecília Midori Sugawara, Viviane Patrícia Senger, Dárcio Kitakawa, Heloíza Tiemi Ono, Elaine Yamada, Celso Tarumoto, Fátima Tiemi Kimoto, Marcos Kenji Nakayama, Andreza da Cunha, Gisele Junko Kan-no, Renato Yoshio loshimoto, Anny Hiratuka, Kátia Regina Yassuda, Edgar Ochi, Carla Rodrigues Horta, Denise Aparecida Rodrigues, Paula Mieco Koizumi Masuyama e aos amigos da UNESP, por poder contar tanto com vocês e desfrutar de tantos momentos felizes.

À Cristhiane Olívia Ferreira do Amaral pela amizade e pelo incentivo que nos dão coragem para buscar os sonhos.

À Irmã Benigna, Wanda Ribeiro, Walter Ribeiro, Avelino Alves e Benedita Fernandes, pela orientação e apoio espiritual.

Aos "meninos" Alexandre, Heitor, Marcelo e Rogério, e à Glória, Daniela, Érika, Liliani, Sheila e Thaís, pela convivência durante este curso de Mestrado. Também aos colegas do curso de Doutorado, Ana Luísa, Daniela Rios, José Vitor, Maria Fernanda, Paloma e Pitty. Em especial, ao Heitor, pela atenção, pelo auxílio imprescindível na confecção de painéis e pelo desprendimento ao compartilhar parte de sua bolsa PAE.

Meu carinho e admiração aos amigos Fabiana, Maria Lígia, Sara, Edmêr e Adriano, que sempre me orientaram pelos caminhos da Odontopediatria, com segurança, exemplo, dedicação e incentivo. 
Aos amigos dos cursos de Mestrado e Doutorado das Áreas de Dentística, Endodontia, Estomatologia, Materiais Dentários, Ortodontia, Patologia Bucal, Periodontia, Reabilitação Oral e Saúde Coletiva desta Faculdade.

Aos funcionários da Biblioteca da FOB-USP, pela amizade, atenção, dedicação e auxílio ímpares durante todos esses anos. $E$ aos funcionários do serviço de xerox, em especial ao Salvador, Marquinhos, Joyce, Ligia e Vanessa, pela prontidão e amizade com que sempre me atenderam.

Ao Aurélio e à Giane, e a todos os funcionários da Seção de PósGraduação da FOB-USP, pela carinho, atenção e disponibilidade durante a realização deste curso.

Ao Prof. Dr. Pedro Ângelo Cintra, Diretor da Faculdade de Odontologia de Presidente Prudente, da Universidade do Oeste Paulista, e aos professores da Disciplina de Odontopediatria, Adilson de Oliveira, Cristhiane Olívia Ferreira do Amaral, Maria Célia D’Angiolli Costa, Maria José Meira Ramos Amorim, Marileide Dall'Oca Alberti, Regina Célia de Oliveira Lima, e em especial, à Profa. Rosa Maria Outeiro Pinto Moreira, por valorizarem tanto as minhas conquistas, pelo incentivo à realização deste curso e pela oportunidade de vivenciar a carreira acadêmica na Área de Odontopediatria.

Ao Prof. Dr. Cláudio Antônio Rabello Coelho, que disponibilizou o Ambulatório de Hepatologia Pediátrica do Hospital das Clínicas da Faculdade de Medicina de Botucatu, Universidade Estadual Paulista, sob sua responsabilidade, para que pudesse conhecer um pouco a realidade de seus pacientes com problemas de saúde crônicos e de seus familiares, e por compartilhar toda a sua atenção, seus ensinamentos, entusiasmos e experiências.

À Roberta Leão Licursi e ao seu filho Lucas pela prontidão com que sempre permitiram que fizesse fotografias usando suas imagens, para a confecção da capa deste trabalho e de material didático durante o curso.

À CAPES pelo auxílio financeiro concedido ao final do curso. 
Meus sinceros agradecimentos a todas as pessoas que contribuíram para a minha formação e para a realização deste trabalho.

"Completou-se uma jornada.

Chegar é cair na inércia de um ponto final.

$\mathcal{N} a$ euforia da chegada, porém,

Há um convite irrecusável

Para uma nova partida! "

Helena Kolody 


\section{SUMÁRIO}

LISTA DE FIGURAS …..........................................................................

LISTA DE TABELAS …................................................................

LISTA DE ABREVIATURAS ………................................................

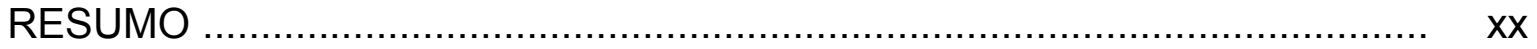

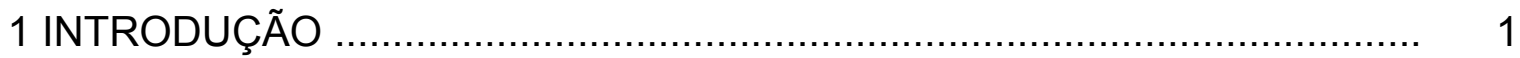

2 REVISÃO DE LITERATURA ……….............................................. 8

2.1 Fluorose dentária - Considerações históricas ………………….......... 9

2.2 Metabolismo do flúor ..................................................................... 17

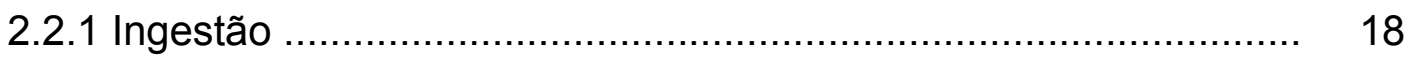

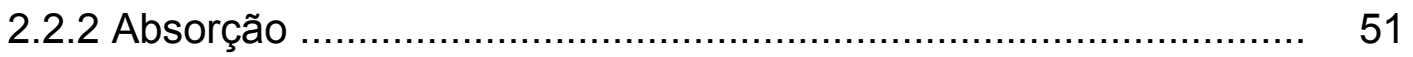

2.2.3 Distribuição e retenção pelo corpo ………………………….... 53

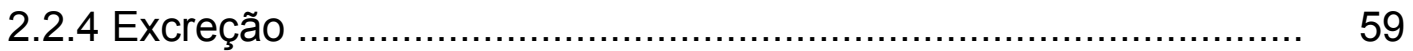

2.3 Período de risco ao desenvolvimento da fluorose dentária ................... 60

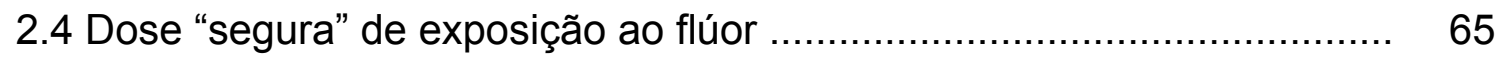

2.5 Consumo de medicamentos pediátricos por problemas crônicos .......... 69

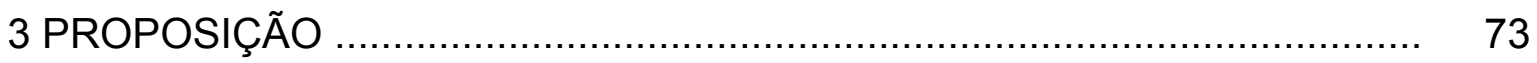

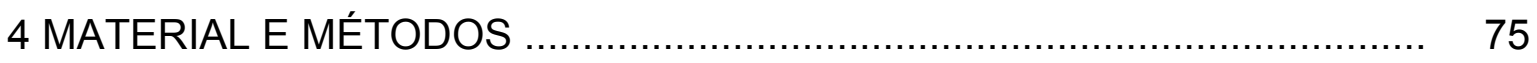

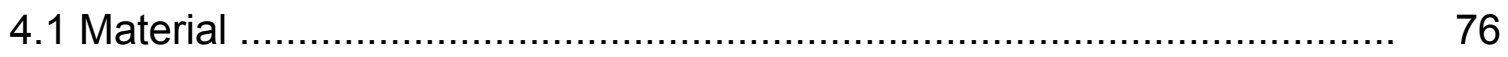

4.1.1 Medicamentos ................................................................. 76

4.1.2 Material utilizado para a análise da concentração de FT ............... 89

4.1.3 Material utilizado para a análise da concentração de FS ............... 91

4.2 Métodos ........................................................................ 95

4.2.1 Seleção dos medicamentos ....................................................... 95

4.2.2 Obtenção dos medicamentos .................................................. 96

4.2.3 Homogeneização das amostras ............................................. 96

4.2.4 Determinação da concentração de FT ........................................ 97

4.2.5 Determinação da concentração de FS ......................................... 103

4.2.6 Validação das análises de FT e FS ........................................... 108

4.2.7 Previsão de risco à fluorose dentária ........................................... 108 
4.2.8 Análise dos resultados .......................................................... 109

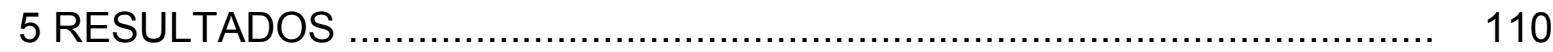

5.1 Dosagem da concentração de FT ................................................. 111

5.2 Dosagem da concentração de FS .................................................. 114

5.3 Previsão de risco à fluorose dentária .................................................... 116

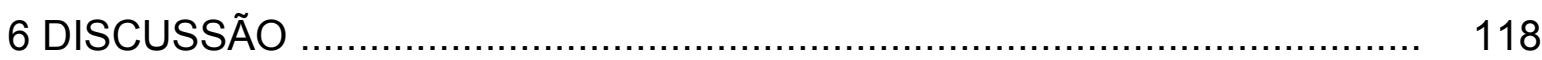

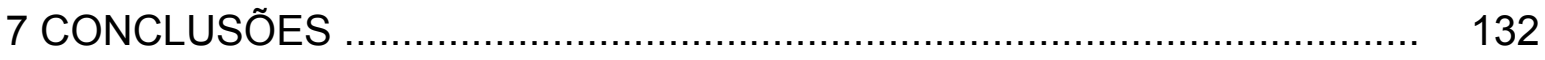

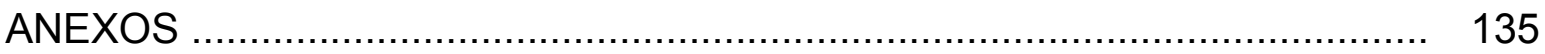

REFERÊNCIAS BIBLIOGRÁFICAS ...................................................... 140

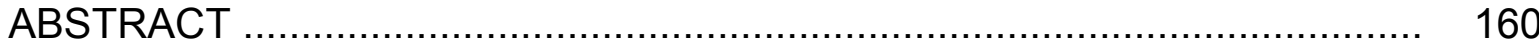




\section{LISTA DE FIGURAS}

FIGURA 4.1 - a) Placa de Petri preparada; b) Adição de 0,1 mL de $\mathrm{NaOH}$ $1,65 \mathrm{M}$; c) Fechamento da placa de Petri com a tampa vaselinada; d) Colocação de 1,0 mL de HMDS-HCl; e) Vedamento do orifício com vaselina e parafilme; e f) Placas empilhadas, dentro de béqueres, sobre mesa agitadora .....

FIGURA 4.2 - a) Colocação das tampas de polietileno sobre bandeja com identificações; b) Secagem da água em estufa; c) Cristais de NaF formados; d) Tubo fechado, contendo $0,4 \mathrm{~mL}$ de ácido acético $0,66 \mathrm{M}$ e agitação para dissolver os cristais de NaF; e) Captação das gotículas para formar um único volume líquido; e f) Leitura com eletrodo em contato com o líquido e resultados em $\mathrm{mV}$

FIGURA 4.3 - Medicamentos selecionados para dosagem de FS

FIGURA 4.4 - a) Tubo de centrífuga preparado; b) Tubos dentro de béquer de polietileno, mantidos em banho-maria à $37^{\circ} \mathrm{C}$, com agitação constante; c) Balanceamento dos tubos aos pares; d) Centrifugação a 3.000 rpm por 5 minutos; e) Registro do volume do sobrenadante; e f) Leitura de FS pelo método direto e resultado obtido em $\mathrm{mV}$

FIGURA 5.1 - Freqüência de distribuição de níveis de FT nos medicamentos

FIGURA 5.2 - Valores das concentrações de FT dos medicamentos maiores que $0,1 \mathrm{ppm}$

FIGURA 5.3 - Valores das concentrações de FT dos medicamentos menores que $0,1 \mathrm{ppm}$

FIGURA 5.4 - Valores das concentrações de FT e FS 


\section{LISTA DE TABELAS}

TABELAS 4.1 a 4.13 - Medicamentos de acordo com a indicação clínica: analgésicos antiinflamatórios antitérmicos, antibióticos, sulfas, medicamentos para nefropatias, corticosteróides, antihistamínicos, broncodilatadores, mucolíticos, antitussígenos, anticonvulsivantes, medicamentos para cardiopatias, medicamentos para gastroenteropatias e polivitamínicos

TABELA 4.14 - Medicamentos selecionados para a análise de FS

TABELA 5.1 Estimativa do consumo diário de $\mathrm{F}$ a partir de FT e seleção dos medicamentos para a dosagem de FS

TABELA 5.2 -

Estimativa do consumo diário de $\mathrm{F}$ a partir dos valores obtidos de FS 


\section{LISTA DE ABREVIATURAS}

SUS-SP = Sistema Único de Saúde do Estado de São Paulo

ADA = Associação Dentária Americana

OMS = Organização Mundial de Saúde

$\mathrm{AAP}=$ Academia Americana de Pediatria

NHIS = Levantamento Nacional de Saúde dos EUA

ppm = parte por milhão

F = Flúor

$\mathrm{FT}=$ Flúor total

FS = Flúor solúvel em $\mathrm{HCl} 0,01 \mathrm{M}$

HMDS = Hexametil-disilazano ou hexametil-disiloxano

HMDS- $\mathrm{HCl}=\mathrm{HMDS}$ em $\mathrm{HCl}$ 6,0 M

$\mathrm{M}=$ Molar

$\mu \mathrm{M}=$ Micromolar

$\mathrm{mV}=$ Milivoltagem

TISAB = "Total Ionic Exchange Adjustment Buffer"

CDTA = Ácido ciclo-hexano diamino tetra-acético

$r=$ Coeficiente de correlação

$p=$ Nível de significância 


\section{RESUMO}

As crianças com problemas de saúde crônicos fazem uso rotineiro de medicamentos e, com o aumento na incidência da fluorose dentária, todas as possíveis fontes de flúor consumidas por crianças na faixa etária de risco devem ser avaliadas. Os objetivos deste estudo foram analisar a presença de flúor total (FT) em 114 medicamentos pediátricos líquidos, através do método da difusão facilitada por HMDS-HCl, de Taves; avaliar a concentração de flúor solúvel em $\mathrm{HCl}$ 0,01 M (FS), após hidrólise ácida, daqueles que apresentaram FT superior à faixa de ingestão "segura" de 0,05 a 0,07 mg F/kg massa corporal/dia, para uma criança de $12 \mathrm{~kg}$, como uma simulação do flúor que estaria biodisponível para absorção no estômago; e destacar os medicamentos que poderiam ser considerados como fatores de risco à fluorose dentária, adotando para comparação a mesma faixa de ingestão de flúor. A partir destas condições experimentais, pôde-se constatar que $99,12 \%$ dos medicamentos apresentaram FT na sua composição, com variações entre 0,0 e 97,8 ppm F. Destes, os medicamentos que revelaram FT igual ou superior à faixa de ingestão para uma criança de $12 \mathrm{~kg}$ após considerar o volume de medicamento consumido diariamente foram: Kalyamon ${ }^{\circledR}$ B-12 (97,80 ppm F; 0,244 mg F/kg/dia), Epelin $^{\circledR}$ (57,89 ppm F; 0,072 mg F/kg/dia), Calcigenol ${ }^{\circledR}$ Irradiado (51,83 ppm F; 0,086 mg F/kg/dia) e Calcigenol ${ }^{\circledR}$ Composto B12 (25,62 ppm F; 0,064 mg F/kg/dia). Eles também apresentaram valores de FS de 1,88 ppm F; 37,15 ppm F; 5,98 ppm F; e 3,58 ppm F, respectivamente, todos inferiores em comparação aos de FT. Nenhum medicamento apresentou teor de FS igual ou superior à faixa correspondente à dose "segura" de flúor. Porém, o Epelin ${ }^{\circledR}(0,046 \mathrm{mg} \mathrm{F} / \mathrm{kg} / \mathrm{dia})$ aproximou-se estreitamente dessa faixa. Constatou-se que o flúor estava presente sem uma finalidade clara na maioria dos medicamentos. Os três medicamentos polivitamínicos mostraram redução mais acentuada da biodisponibilidade do flúor no estômago, por serem enriquecidos com sais minerais. Considerando-se somente a absorção gástrica, o Epelin ${ }^{\circledR}$ poderia representar risco à fluorose quando associado a outras fontes de flúor. Porém, recomenda-se cautela com relação aos demais polivitamínicos, pois desconhece-se a taxa de absorção intestinal, além de não ser possível controlar as associações com as demais fontes de flúor, que normalmente ocorrem. 
1 INTRODUCÃO 


\section{INTRODUÇÃO}

O uso do flúor ${ }^{1 *}$ tem ocupado importante destaque na Odontologia, a partir do momento em que se comprovou seus benefícios e sua efetividade na prevenção da cárie dentária, sobretudo em crianças ${ }^{10}$. Esse momento coincidiu com o início de uma filosofia de promoção de saúde baseada na prevenção da doença, que é uma realidade nos dias atuais. Assim, o flúor vem sendo largamente utilizado de várias maneiras em todo o mundo, concomitantemente ao estímulo de diversos programas preventivos de saúde bucal ${ }^{26,58,137}$.

Porém, à medida que se observa um declínio na prevalência e na incidência da cárie nas três últimas décadas, nota-se um aumento simultâneo na prevalência da fluorose dentária, o que a torna uma das principais preocupações da Odontopediatria', 20, 30, 61, 72, 81, 117, 128, 148, 162, 181.

De acordo com FEJERSKOV et al. ${ }^{58}$ (1994), a preocupação com os problemas de fluorose vem crescendo, e relatórios de várias partes do mundo indicam um visível aumento na prevalência e na gravidade, tanto em países desenvolvidos como naqueles em desenvolvimento, em comunidades com água fluoretada ou não.

\footnotetext{
$1^{*}$ Termo genérico para definir as formas químicas iônica (íon flúor ou fluoreto) e ionizável (iônica ou covalente) do elemento flúor.
} 
Introdução

A fluorose dentária se caracteriza por uma alteração na estrutura do esmalte, provocada pela intoxicação sistêmica de íons flúor, durante a fase de formação do esmalte 1 , 5, 9, 17, 20, 39, 77, 94, 153, 162, 171, 181 . Portanto, a má formação ocorre somente durante a amelogênese, e é de caráter irreversível.

É importante observar que o flúor tem afinidade com a hidroxiapatita, depositando-se em tecidos mineralizados, como o dente e o osso ${ }^{10,23,39,114}$.

Estudos sobre a fisiopatologia do flúor na amelogênese têm permanecido inconclusivos. Várias hipóteses foram estudadas e, atualmente, é preferível dizer que a interferência é multifatorial, envolvendo uma série de eventos intra e extracelulares, que podem se manifestar sobre os ameloblastos, sobre a enucleação e o crescimento cristalino e, sobre a homeostasia do cálcio $9,17,39,40,57,123,137,181$. Porém, quando a exposição ao flúor é suspensa, o ameloblasto é capaz de voltar a produzir uma matriz sem alterações ${ }^{123,137,147 .}$

Sendo dose-dependente, seu aspecto clínico está diretamente relacionado à interação das concentrações de flúor no plasma e ao tempo (momento e duração), podendo variar desde linhas brancas finas até um esmalte gravemente opaco e calcáreo, que pode se fraturar logo após a erupção e/ou se pigmentar 3 , 5, 10, 17, 20, 39, $40,55,57,123,138$

Histologicamente, a ingestão prolongada de flúor durante o período de formação do esmalte provoca um aumento na porosidade de sua superfície externa (hipomineralização) $^{9,10,20}$. Os poros, que refletem um aumento no tamanho dos espaços entre os cristais do esmalte, são preenchidos com proteínas e água. Devido às propriedades ópticas da água estarem próximas das do esmalte, as propriedades 
Introdução

ópticas deste são, às vezes, difíceis de serem vistas. Todavia, quando a superfície está seca, a água contida no esmalte poroso é parcialmente substituída por ar, e o grau de opacidade visto reflete diretamente o grau de porosidade do esmalte. Com o aumento da gravidade, toda a superfície do dente exibe áreas brancas, distintas, irregulares, opacas ou nebulosas. As descolorações castanhas, que podem ocorrer, na verdade, são manchas resultantes da absorção de substâncias da alimentação, que se desenvolvem gradualmente após a erupção dos dentes. Nos estádios mais graves, a superfície do dente pode apresentar perda focal do esmalte externo, formando depressões ${ }^{58}$.

Devido à etiologia sistêmica, sempre há uma certa simetria no grau em que os dentes homólogos são afetados ${ }^{9}, 10,17,20,40,56,123,171$, embora nem todos os dentes sejam igualmente afetados. Os dentes menos afetados são os incisivos e os primeiros molares permanentes, ao passo que os pré-molares e outros molares permanentes são os mais gravemente afetados.

Na dentição decídua, o padrão de distribuição da fluorose é similar ao encontrado nos dentes permanentes. Os molares decíduos são mais gravemente afetados que os incisivos, refletindo novamente a ordem de erupção desses dentes ${ }^{9}$, 10, 123, 175. Entretanto, os dentes decíduos são menos afetados que os seus sucessores permanentes, pois seu esmalte geralmente é menos exposto ao flúor, mais fino, mais branco e não exibe os padrões incrementais vistos na superfície do esmalte permanente, sendo as formas mais brandas de fluorose mais difíceis de serem diagnosticadas ${ }^{17,20,58,175}$. 
Introdução

A quantidade de ingestão diária de flúor, geralmente mencionada na literatura como "ótima" para a prevenção da cárie e "segura" para a fluorose, é de

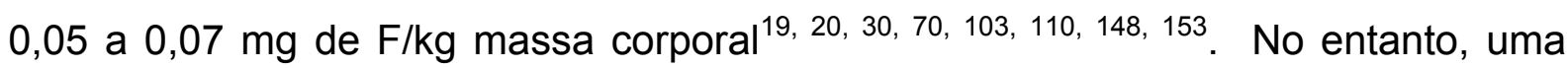
quantidade tão baixa quanto acima de $0,022^{16}$ ou $0,04 \mathrm{mg} \mathrm{F} / \mathrm{kg}^{\text {massa corporal }}{ }^{12,54,}$ 58,162 pode resultar em fluorose.

Hoje a criança é exposta a muitas fontes de flúor ${ }^{72,117}$ e alguns estudos, a respeito de sua etiologia, têm avaliado principalmente a água de abastecimento

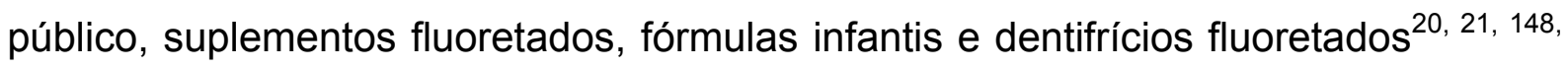
153, 162, 171. Em adição, alguns alimentos e bebidas infantis manufaturados podem ser importantes contribuintes para a ingestão total de flúor diária ${ }^{20,70,72,168}$. Todas as possíveis fontes de flúor consumidas por crianças na faixa etária de risco à fluorose devem ser avaliadas ${ }^{23}, 30,72$, uma vez que a prevalência e a gravidade estão aumentando, e o fator de risco mais importante é a quantidade total de flúor ingerida

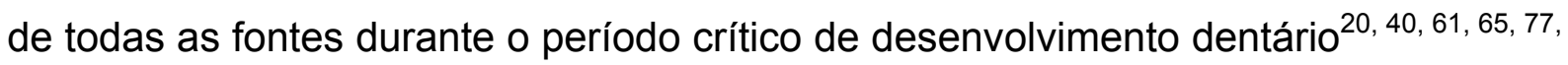
$88,106,128,162$

Recentemente, CASTRO et al. ${ }^{25}$ (2000), ao realizar um levantamento com 51 crianças no Rio de Janeiro (RJ), constataram que $11,8 \%$ apresentavam sinais de fluorose, sendo que a história de ingestão de vitaminas contendo flúor (Calcigenol ${ }^{\circledR}$ Hoechst Marion Roussel; e Kalyamon ${ }^{\circledR}$ - Janssen-Cilag) teve relação significante entre os possíveis fatores de risco para a fluorose nesse estudo.

Muitas crianças, principalmente as com problemas de saúde crônicos, utilizam rotineiramente medicamentos ${ }^{41,53,76,145}$, ou mesmo vitaminas, e torna-se, dessa forma, relevante a análise da presença de flúor na composição dos mesmos. 
Introdução

O uso de medicamentos na maioria das vezes é de ocorrência diária, com alta freqüência, por um longo período de tempo, ou com recorrência. Seus ingredientes ativos são fundamentais para a melhora e a manutenção das condições de saúde da criança, porém outros ingredientes podem ser perigosos, com efeitos indesejáveis ${ }^{52,53}$. E há falta de conhecimento sobre a presença de fluoretos em medicamentos que não sejam algumas vitaminas, que já foram citadas em trabalhos anteriores $^{62,171 .}$

A literatura científica relata a falta de conhecimentos de pais e de médicos, até mesmo de dentistas sobre a fluorose, e mostra-se vasta com relação à excessiva exposição das crianças ao flúor, decorrente do descuido e do despreparo de pais e profissionais ao indicar e administrar produtos fluoretados ${ }^{17,79,117,118,136,167 .}$

O flúor pode ser tóxico, é considerado um remédio e, como tal, deve ser utilizado de modo consciente, com uma indicação clara e segura sobre a doença, isto é, de modo terapêutico e para casos específicos de risco à cárie, através de uma conduta adequada e dentro da faixa de segurança ${ }^{115}$.

Mais recentemente a Secretaria da Saúde do Estado de São Paulo vem incentivando e promovendo esta prática na saúde pública, com a instituição das "Recomendações sobre o uso de produtos fluorados no âmbito do SUS/SP em função do risco de cárie dentária”, dispostas na Resolução SS - de 12.200 ${ }^{115,151}$.

Torna-se, portanto, imprescindível a realização de estudos no sentido de identificar potenciais fatores de risco para o desenvolvimento da fluorose e promover o uso racional do flúor, da mesma forma que conhecer a presença ou a ausência de flúor nos medicamentos e, sendo positivo, constatar sua concentração. 
Introdução

Estudos dessa natureza podem induzir uma atuação multidisciplinar entre fabricantes de medicamentos, profissionais das classes odontológica, médica e farmacêutica e, pais, para difundir conhecimentos e discutir práticas importantes para a manutenção integral da saúde bucal das crianças. 
2 REVISÃO DE LITERATURA 


\section{REVISÃO DE LITERATURA}

Para uma melhor abordagem deste trabalho e por questão didática, este capítulo será dividido em cinco partes específicas, as quais, embora não tenham como objetivo esgotar os assuntos, estarão em uma seqüência buscando coerência de informações:

- Fluorose dentária - Considerações históricas

- Metabolismo do flúor

- Período de risco ao desenvolvimento da fluorose dentária

- Dose "segura" de exposição ao flúor

- Consumo de medicamentos pediátricos por problemas de saúde crônicos

\subsection{FLUOROSE DENTÁRIA - CONSIDERAÇÕES HISTÓRICAS}

A fluorose dentária é provavelmente tão antiga quanto à raça humana. Certamente, dentes com manchas escuras e desfiguradas foram encontrados em crânios com milhares de anos de idade. Todavia os primeiros relatos da literatura científica são datados de uma centena de anos atrás ${ }^{58}$. 
Em 1901, John Macauley EAGER ${ }^{42}$, médico americano que residia em Nápoles, escreveu um relato que depois foi reconhecido como a primeira documentação científica sobre a fluorose dentária. Ele descreveu detalhadamente sobre uma descoloração marrom dos dentes, comum na região de Pozuoli, Itália. Esses dentes eram conhecidos pelo nome de "denti di chiaie". Na época, supunhase que essas manchas estavam relacionadas com gases vulcânicos dissolvidos na água da região.

Após informes de outras regiões do globo, em particular, das observações feitas por BLACK; McKAY ${ }^{18}$, da "mancha marrom do Colorado", em 1916, descreveu-se que esse distúrbio mantinha uma estreita correlação com a presença de flúor na água potável. Esses defeitos foram identificados como esmalte manchado, ou fluorose dentária crônica endêmica, desde então fluorose dentária.

Na década de 30, estudos experimentais e epidemiológicos em animais e humanos, conduzidos nos EUA por Frederick McKay e H. Trendley Dean, continuaram esclarecendo a relação entre o nível de fluorose dentária e a concentração de flúor na água potável ${ }^{34,39, ~ 58,109 .}$

DEAN $^{32}$, em 1934, desenvolveu um índice de fluorose e o usou para relacionar a gravidade com o nível de exposição ao flúor. Embora seus estudos tivessem inicialmente o objetivo de investigar a relação entre flúor e fluorose dentária, seus levantamentos também revelaram que a presença de flúor na água potável estava associada à baixa predominância de cárie dentária ${ }^{36}$. Em 1942, DEAN $^{35}$ realizou nos EUA um levantamento em 7.257 crianças com idades entre 12 e 14 anos, residentes em 21 cidades de 4 estados diferentes. Relacionou em um 
gráfico o índice de cárie e a concentração de flúor na água de abastecimento, observando que na concentração de 1 ppm havia redução de $50 \%$ de cárie, sendo que nenhuma vantagem adicional era obtida com concentrações maiores de flúor. Dean também estipulou que $10 \%$ das pessoas nascidas e criadas nessas comunidades com água fluoretada em níveis satisfatórios demonstraram sinais de formas brandas de fluorose. Essas descobertas levaram a uma grande agitação quanto ao uso do flúor na prevenção da cárie.

O entusiasmo que se seguiu à descoberta do efeito anticárie fez com que essa propriedade do íon fosse lembrada como o principal efeito de sua ingestão, ao passo que sua verdadeira propriedade biológica de provocar distúrbios de mineralização de tecidos do corpo fosse considerada meramente como um "efeito colateral" indesejável $^{58,137}$. O predomínio desse ponto de vista causou dificuldades consideráveis nos anos subseqüentes àqueles profissionais que estavam tentando compreender como as propriedades cariostáticas do flúor poderiam ser aproveitadas sem induzir a fluorose.

Esse ponto de vista das propriedades biológicas do flúor conduziu ao desenvolvimento de uma teoria pré-eruptiva que afirmava que o flúor exercia seu efeito anticariogênico quando era incorporado aos cristais que compunham o esmalte dos dentes ${ }^{58,114,161,171}$. Acreditava-se que isso fazia com que o esmalte fosse mais resistente ao ataque ácido, resultante das atividades metabólicas da placa dentária nas superfícies do dente. A teoria era apoiada por estudos sobre as propriedades de dissolução dos cristais do esmalte sob condições extremas em laboratório, que demonstraram que os cristais se apresentavam mais resistentes ao 
ácido quando íons hidroxila eram parcialmente substituídos por fluoretos. Era, portanto, considerado importante que o flúor fosse adicionado à água potável, para assegurar que pudesse se incorporar ao esmalte durante seu período de formação e, dessa forma, "proteger" os dentes contra a cárie. Esse foi o conceito que persistiu durante muito tempo.

A fluoretação das águas passou a ser considerada o procedimento profilático coletivo mais eficaz na prevenção da cárie ${ }^{61,162}$, e o "momento da verdade na história da fluoretação das águas", conforme Frank McCLURE ${ }^{108}$ (1970), teve início em 25 de janeiro de 1945, quando Grand Rapids, Michigan, EUA, tornou-se a primeira cidade do mundo a ajustar sua concentração de flúor na água visando à promoção da saúde dentária.

Logo depois, a fluoretação foi implantada em outras cidades dos EUA e mais tarde em outros países. Em 1950 a Associação Dentária Americana (ADA) e, em 1969, a Organização Mundial de Saúde (OMS) recomendaram a utilização da fluoretação das águas como um método preventivo e eficaz da cárie ${ }^{129}$.

Esse método vem sendo adotado no Brasil desde 1953, quando foi fluoretada a água de abastecimento público do município de Baixo Guandu, Espírito Santo, o que iniciou discussões para a implantação da fluoretação em outros estados e municípios ${ }^{61,}{ }^{115}$. Em 1974, foi aprovada a Lei Federal $\mathrm{n}^{\circ}$. 6.050, regulamentada pelo Decreto 76.872 , de 22/12/75, que tornava obrigatória a fluoretação das águas de abastecimento público em municípios com estação de tratamento de água. A operacionalização da medida teve seus padrões 
estabelecidos pelo Ministério da Saúde com a edição da Portaria 635, de $26 / 12 / 75^{115}$

Em 1994, estimou-se que pelo menos 39 países estavam inaugurando programas de fluoretação, atingindo mais de 170 milhões de pessoas ${ }^{186}$. Esses números provavelmente só não eram maiores devido aos esforços de grupos antifluoretacionistas ${ }^{58,129}$.

Todavia, a adição de flúor nas fontes de águas potáveis destinadas ao abastecimento de uma comunidade nem sempre foi possível. Para superar tais dificuldades, foram exploradas outras formas de prescrever flúor, como sua adição ao sal doméstico, ao leite, ao açúcar, às gotas de vitaminas, sua formulação em comprimidos, e o seu uso tópico ${ }^{30,58,114,129}$, apesar dos resultados das tentativas clínicas subseqüentes mostrarem que a capacidade em reduzir a cárie era decepcionante e mais baixa que a da fluoretação da água a aproximadamente 1 ppm.

Visto que já havia sido mostrado que o flúor tinha efeitos tóxicos no esmalte dos dentes em desenvolvimento, foi dada atenção à questão do que poderia constituir o "nível ideal de flúor" nas fontes de água potável, isto é, a concentração de flúor na água potável que resultaria em "proteção" máxima contra a cárie e que, ao mesmo tempo, causaria mínima fluorose ${ }^{67,68,140}$.

Baseado em seus estudos sobre o "limiar mínimo de fluorose dentária endêmica crônica", $\operatorname{DEAN}^{33}$ (1936) concluiu que "quantidades não excedendo 1 parte por milhão (ppm) de flúor $(F)$ não apresentam nenhum significado na saúde pública", sendo aceito que entre 10 e $20 \%$ da população poderia apresentar sinais 
de fluorose muito branda, não representando risco estético em vista da obtenção do efeito simultâneo de prevenção contra a cárie. Deve-se notar que afirmar que 1 ppm F "não apresenta nenhum significado na saúde pública" não é o mesmo que dizer que nenhuma fluorose ocorre na população. Os próprios dados de Dean mostraram que os efeitos tóxicos do flúor no esmalte eram manifestados até mesmo em comunidades expostas a concentrações de flúor abaixo de $1 \mathrm{ppm}$. Este fato importante seria completamente ignorado nos anos seguintes por muitos epidemiologistas e profissionais da saúde pública ${ }^{58}$.

Mais recentemente, estudos laboratoriais amplos, combinados com reavaliações de dados clínicos já publicados, indicaram que o mecanismo através do qual o flúor exercia seu efeito anticariogênico era diferente do que até então se acreditava. Esses estudos mostraram que o flúor podia interferir no verdadeiro processo da cárie, quando presente até mesmo em concentrações muito baixas (menos que 1 ppm) dentro da boca, mesmo que não tivesse sido incorporado anteriormente pelos cristais do esmalte dos dentes. Descobriu-se que o flúor podia intervir nos processos de desmineralização e remineralização que ocorrem nas lesões, apenas estando presente quando e onde a cárie estivesse realmente ocorrendo. Essas descobertas tiveram efeitos profundos na compreensão de como as propriedades anticariogênicas do flúor podiam ser aproveitadas, ao mesmo tempo em que eram evitados os efeitos tóxicos do flúor no esmalte dos dentes em formação. Além disso, essas descobertas levaram ao desenvolvimento do atual conceito de que, ao invés de ser um "protetor" contra a cárie, o flúor trabalha principalmente de forma tópica, para reduzir o índice de progressão das lesões de 
cárie, e que o flúor importante é aquele mantido em quantidades pequenas e constantes na cavidade bucal $^{10,23,26,30,161,171 .}$

Mas o flúor continuou sendo largamente utilizado, sob diversas formas, como instrumento eficaz na prevenção e no controle da cárie, sendo considerado elemento estratégico das tecnologias empregadas para prevenção em saúde bucal $^{115,151}$.

Nos anos 80 e 90, houve grande expansão na utilização de produtos fluoretados no Estado de São Paulo. O principal veículo para o flúor continuou sendo a água de abastecimento público. Contudo, estava presente também em dentifrícios, soluções para bochechos, géis para aplicações tópicas e em outros produtos. O uso do flúor em larga escala, combinado com ações educativas e práticas adequadas de higiene pessoal, compondo sistemas de prevenção, vem produzindo importantes mudanças no perfil epidemiológico da cárie ${ }^{115}$.

Porém, ao mesmo tempo em que se constata a redução da incidência da cárie em muitos países, nos últimos anos, verifica-se também o aumento da preocupação com os problemas da fluorose dentária. Relatórios de várias partes do

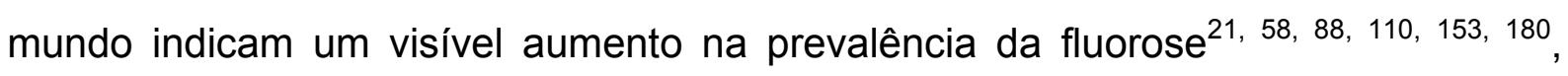
principalmente nas formas muito leve, leve e moderada $20,58,70,117,122,133,134,148,158$, 161, 183 e em comunidades sem água de abastecimento fluoretada ${ }^{39,61,148,161}$. A prevalência tem variado de $3 \%$ a $42 \%$ em comunidades sem água fluoretada ${ }^{84,87,134}$ e entre $45 \%$ e $81 \%$ em áreas com fluoretação ótima ${ }^{28,84,87,183}$. Essa ocorrência tem sido atribuída, sobretudo, à exposição excessiva, até mesmo não intencional, de crianças ao flúor, devido à disponibilidade de diversas fontes do mineral ${ }^{20,21,61,162}$. A 
diferença na prevalência de fluorose entre comunidades com e sem água fluoretada tem se estreitado consideravelmente $27,28,88,152$.

Em diversos países em desenvolvimento, a fluorose tem ocorrido em níveis inesperadamente altos em relação à exposição ao flúor. Nos países industrializados, onde o uso tópico do flúor foi feito em grande quantidade durante as últimas duas décadas, alega-se que a fluorose também esteja aumentando ${ }^{58}$.

Para CURY ${ }^{30}$ (2001), no presente e no futuro a discussão será sobre a fluorose tendo em vista relatos do aumento de sua prevalência. Embora no Brasil não se possa afirmar com bases epidemiológicas sobre um aumento de prevalência da fluorose, do ponto de vista individual isto tem alarmado o profissional, baseado no que ele tem encontrado no consultório. Assim, uma abordagem sobre o risco de fluorose é pertinente agora já pensando no futuro.

Desde então, a fluorose vem sendo questão central em todos os programas que procuram aproveitar as propriedades únicas do flúor para controlar e prevenir a cárie $^{26,137}$. Negligenciando o efeito tóxico do flúor sobre o esmalte dos dentes em desenvolvimento, por muito tempo os profissionais de saúde pública apresentaram a fluorose simplesmente como um problema cosmético, e não de natureza sistêmica. A despeito de a questão ter sido estudada durante muitos anos, a compreensão pública das questões envolvidas não foi melhorada e, ainda hoje existe uma confusão sobre o que a fluorose é de fato e como e por que ela ocorre.

Com o foco voltado à fluorose dentária, estão ocorrendo importantes mudanças a respeito do uso do flúor na Odontologia, quer seja em termos de 
Literatura

benefícios como de riscos, de modo a buscar seu uso racional para a promoção da saúde integral do indivíduo.

\subsection{METABOLISMO DO FLÚOR}

A ocorrência e a gravidade da fluorose dentária podem variar entre os diferentes indivíduos e populações, devido à existência de fatores ambientais e fisiológicos, bem como à maior exposição e disponibilidade a diferentes fontes de flúor. Tais fatores, mesmo em comunidades com água não fluoretada, podem resultar em concentrações aumentadas de flúor no fluido corporal e alterações na manifestação individual em resposta aos efeitos tóxicos do flúor em tecidos mineralizados $^{10}, 39,58,94,180$. Entretanto, há uma relação direta entre o aumento da quantidade de flúor ingerido por um indivíduo e a subseqüente ocorrência e gravidade da fluorose ${ }^{58,94,171,180}$.

Para compreender como diferentes fatores podem influenciar o grau de suscetibilidade de um indivíduo à fluorose, é preciso analisar as principais características do metabolismo do flúor no corpo humano. Fundamentalmente, existem quatro componentes a serem considerados: 1) ingestão, 2) absorção, 3) distribuição e retenção do flúor pelo corpo e, finalmente, sua 4) excreção. Cada um dos quatro componentes pode ser afetado de uma forma que pode alterar o resultado final. 


\subsubsection{INGESTÃO}

O flúor é um componente natural da biosfera. Como é o mais eletronegativo de todos os elementos químicos, raramente é encontrado na natureza em sua forma de elemento puro ${ }^{114}$. Combinado quimicamente em forma de fluoretos, ocupa o $13^{\circ}$. lugar por ordem de freqüência de aparição na crosta terrestre. Deste modo, é encontrado em várias concentrações, em quase todos os seres animados e inanimados ${ }^{23}$

De acordo com NARVAl et al. ${ }^{115}$, em 2002, como tudo na natureza, o flúor também pode ser tóxico. O importante é a dosagem, que vai estabelecer a diferença entre remédio e veneno. A distância entre dose benéfica e dose tóxica é pequena (25 vezes $)^{153}$. A toxicidade do flúor pode ser caracterizada em aguda e crônica, sendo a primeira relacionada com a ingestão de grande quantidade de flúor de uma única vez e, a segunda, com a ingestão de pequena quantidade de flúor durante um período prolongado. Seus efeitos podem variar desde fluorose dentária, distúrbios gástricos reversíveis até a fluorose esquelética e mesmo a morte ${ }^{23,180}$.

A fonte predominante de flúor para o homem é a água ${ }^{30,58,114}$. O flúor pode estar presente na água tanto naturalmente como em conseqüência da fluoretação ${ }^{10}$ 81

Em seu relatório, FEJERSKOV et al. ${ }^{58}$ (1994) citaram que a fluorose não ocorre apenas em conseqüência do uso do flúor na prevenção da cárie, mas também devido à existência natural de flúor na água potável utilizada por milhões de pessoas em todo o mundo. Há populações que podem estar expostas a 
concentrações de flúor na água que resultam até em osteofluorose ou fluorose esquelética. Naturalmente para muitas pessoas, o simples acesso à água potável constitui um problema de saúde pública por si só e, quando a água está disponível, geralmente há pouca escolha quanto à sua qualidade.

A presença de flúor natural na água é imprevisível no Brasil. Na maioria dos municípios, a quantidade de flúor é muito baixa, variando de 0,1 a 0,3 ppm, porém em algumas cidades como Piracicaba e Pereira Barreto, no estado de São Paulo, a concentração pode atingir níveis de mais de $4,0 \mathrm{ppm}^{29}$. Então, a água de poços artesianos recém-perfurados deve ser analisada antes de ser fornecida para a população ${ }^{30}$.

MURRAY ${ }^{114}$, em 1992, afirmou que a ingestão de flúor com a água dependia 1) da sua concentração, 2) da idade da pessoa, 3) das condições climáticas e 4) dos hábitos alimentares.

A fluoretação da água de abastecimento público deve continuar ${ }^{80,123}$, pois é o método mais adequado, eficiente, seguro, econômico e perene para o controle da cárie, sendo bem estabelecido pela literatura científica ${ }^{10,30,62,69,117,162}$. No entanto, deve ser controlado em termos de riscos/benefícios, pois, se a subdosagem não traz benefícios anticariogênicos, a sobredosagem está associada com a fluorose ${ }^{14,162}$.

A proporção de flúor é estabelecida considerando-se o clima, o consumo médio e os hábitos alimentares da população. Assim, tem sido realizada com base na média anual das temperaturas máximas diárias ${ }^{10,61,117}$. Isto porque, dentro de uma dada população, o fator mais importante para determinar o volume de água consumido seria a temperatura diária máxima reinante na zona correspondente. 
Em alguns casos, a variação na incidência e no nível de gravidade da fluorose não pôde ser totalmente explicada pelo conteúdo de flúor na água. Por exemplo, Dean encontrou incidências similares de fluorose em áreas com 0,4 ppm e com 1,2 ppm de flúor na água potável. Como as áreas com 0,4 ppm tendiam a estar em zonas climáticas mais quentes, foi sugerido que as pessoas que viviam nessas zonas poderiam consumir mais água por dia e, portanto, ingeriam mais flúor através da água do que aquelas que viviam em climas mais temperados ${ }^{58}$.

Estudos efetuados posteriormente nos EUA indicaram que recém-nascidos e crianças, na realidade, tendiam a beber mais água e outros líquidos em climas mais quentes ${ }^{94}$.

Então, fórmulas foram desenvolvidas para estimar a "concentração ideal" de flúor na água potável, para diferentes temperaturas médias anuais máximas nas diferentes zonas climáticas e, em seguida, efetuar recomendações. Uma destas foi a de que 0,7 ppm de flúor seria a "concentração ideal" em climas tropicais ${ }^{137}$.

Todavia, essas recomendações provaram ser de valor duvidoso. Um número crescente de levantamentos indicou recentemente a maior prevalência de fluorose em áreas onde a concentração de flúor é abaixo do nível recomendado pelas fórmulas ${ }^{61,117}$.

Através da Portaria 56 de 14/03/77, do Ministério da Saúde, publicada no Diário Oficial da União do dia 15/06/77 foi regulamentado o padrão da potabilidade da água no território brasileiro, que estabeleceu que o Valor Máximo Permissível para o flúor na água potável seria de 0,6 a 1,7 ppm. Valores acima destes classificariam a água como não potável ${ }^{129}$. 
A OMS ${ }^{187}$ sugeriu que a água deveria ter um teor de flúor entre 0,7 a 1,2 ppm, considerando a quantidade de ingestão de água de acordo com a variação de temperatura, como o caso do Brasil. O teor considerado "ótimo" para a região Sudeste do país seria de 0,7 ppm de flúor, mesmo assim, em torno de $10 \%$ da população desenvolveria a fluorose em um nível clinicamente aceitável, conforme ASSIS; OLIVEIRA ${ }^{9}$ (1998). Por outro lado, se a concentração de flúor fosse superior ao teor "ótimo" (2X, 3X, 4X), a intensidade da fluorose aumentaria, atingindo níveis que afetariam a estética e/ou a função dos dentes.

Estudos nas fontes de abastecimento de água potável efetuados em várias partes do mundo demonstraram recentemente que pode haver marcantes variações na concentração de flúor, mesmo durante curtos períodos. Deve-se observar que até mesmo pequenas oscilações podem afetar o eventual grau de fluorose ${ }^{61}$. Oscilações entre 0,8 e 1,0 ppm, comuns em fontes de abastecimento de água fluoretadas artificialmente, podem ser suficientes para se refletirem no nível de gravidade das mudanças no esmalte ao longo da superfície dentária ${ }^{58}$.

TAVARES; BASTOS ${ }^{162}$, em 1999, ao realizar um monitoramento externo da concentração de flúor das águas de abastecimento público de 49 pontos diferentes da cidade de Bauru - SP, durante 6 meses, notaram uma variação de 0,05 a 1,40 ppm de flúor presente nas amostras. Considerando-se um teor "ótimo" de flúor na água de consumo da cidade entre 0,6 e 0,8 ppm, apenas $16,36 \%$ do total de 330 amostras apresentaram nível regular. Em 10 amostras foram encontrados teores elevados de flúor, maiores que 0,8 ppm, mas nenhum dos pontos revelou ter média desse íon superior ao nível "ótimo". 
Portanto, uma fiscalização rigorosa quanto ao teor de flúor adicionado à água de consumo é imprescindível no sentido de se garantir a eficácia do método na prevenção tanto da cárie como da fluorose. A Resolução 142/94, do Plenário do Conselho Nacional de Saúde, exige a verificação da qualidade da fluoretação por parte dos Serviços Públicos de Saúde ${ }^{14,162}$. A ação setorial de saúde específica em relação a este produto é a vigilância sanitária, que deve ser feita por órgãos especializados no município (SUS-SP), com base no princípio do heterocontrole ${ }^{151}$.

Recentemente, a altitude mostrou estar associada à maior incidência e gravidade da fluorose ${ }^{10,58,94,104,149}$. Estudos efetuados no leste da África indicaram que populações que vivem em altitudes relativamente altas são mais suscetíveis aos efeitos tóxicos do flúor no esmalte dentário em desenvolvimento ${ }^{104,}{ }^{149}$. Nas populações expostas às concentrações similares de flúor na água potável, a incidência da fluorose aumentou de $36 \%$ ao nível do mar, para $78 \%$ a $1.500 \mathrm{~m}$ de altitude e para $100 \%$ a $2.400 \mathrm{~m}$ de altitude ${ }^{58}$. Da mesma forma, havia um aparente aumento no nível de gravidade da fluorose nos diferentes tipos de dente nessas áreas $^{10,58}$.

A razão exata desse fenômeno é desconhecida até o momento e as descobertas precisam ser confirmadas por mais estudos em outras partes do mundo. Entretanto, é possível que certas mudanças metabólicas ocorram no corpo humano com o aumento da altitude, as quais afetam indivíduos particularmente suscetíveis a até mesmo doses muito baixas de fluoretos ${ }^{30,81}$.

Muitos estudos recentes têm relatado o aumento da prevalência de fluorose em áreas com água fluoretada e em áreas sem água fluoretada $27,39,61,69,84,87,88,134$, 
Literatura

148, 158, 161 . Todos os autores acreditam que a fluorose é conseqüência da ingestão de flúor, acima da dose total diária recomendada para segurança $(0,05$ a $0,07 \mathrm{mg} \mathrm{F} / \mathrm{kg}$ massa corporal), nos primeiros anos de vida da criança. No entanto, as principais fontes de flúor responsáveis pelo aparecimento da fluorose são bastante questionadas $^{77,98,99,123,144,161}$. Esses estudos têm tido diferentes propósitos, usado vários índices de diagnóstico e focalizado diferentes populações, muitas, expostas a múltiplas fontes de exposição ao flúor. Esta variabilidade tem dificultado a comparação de seus resultados ${ }^{20}$.

Com relação ao flúor presente na água de consumo, a maioria dos autores concorda que a prevalência de fluorose é maior em área fluoretada do que em área não-fluoretada ${ }^{77,141,142,159}$. No entanto, LEWIS; BANTING ${ }^{102}$ (1994), FERREIRA et al. $^{61}$ (1999) e JACKSON et al. ${ }^{88}$ (2002) comentaram que a diferença entre essas áreas tem sofrido uma notável redução com o passar do tempo e que a contribuição somente da fluoretação das águas sobre o aparecimento da fluorose, não pode ser determinada devido à existência de outras fontes de flúor.

Antes de 1940, as fontes de flúor para a maioria dos indivíduos eram basicamente a água e a comida. Desde então, outros veículos contendo flúor foram introduzidos no mercado, e a ingestão dessas várias outras fontes nos primeiros anos de vida da criança pode ocorrer em quantidade suficiente para causar fluorose $^{8,14}, 20,77,99,128,148,162$. A água fluoretada tem sido responsabilizada por apenas $40 \%$ desse quadro e os $60 \%$ restantes têm sido atribuídos às outras fontes de flúor $^{102}$. 
Nos últimos anos há um crescente aumento no consumo de águas minerais engarrafadas no Brasil, como em outros países ${ }^{14,165,170 .}$

O Ministério da Saúde expediu a portaria 56, de 14/03/1977, para águas minerais engarrafadas, as quais deveriam seguir o seguinte critério: "O valor máximo permitido para o íon flúor na água potável é de 0,6 a 1,7 mg/L, sendo que, valores acima destes classificam a água como não potável". Deve ser lembrado que 1,0 mg F/L ou kg equivale a 1,0 $\mathrm{ppm}^{11}$. Pelo Código de Águas Minerais da legislação brasileira, é permitido que se classifiquem como fluoretadas águas que acusem em sua composição o íon flúor em concentrações adequadas. Porém, há uma má fiscalização que também não traz benefícios em termos de controle da cárie e do risco de fluorose ${ }^{14,129,170}$.

TOUMBA; LEVY; CURZON ${ }^{165}$ (1994) realizaram uma pesquisa a fim de avaliar a concentração de flúor presente nas águas de beber comercializadas na Inglaterra. Encontraram resultados de concentrações de flúor díspares daquelas observadas nos rótulos dos produtos. Alertaram, então, para a possibilidade de indução de fluorose nos casos em que a concentração excedia o usual permitido para a prevenção da cárie. Assim, pais deveriam estar atentos e dentistas deveriam tomar cuidado ao indicar suplementos de flúor às crianças que faziam uso dessa água. Os autores concluíram que seria necessário um controle da real concentração de flúor presente na garrafa d'água e sua menção no rótulo.

Em semelhante pesquisa, VILLENA; BORGES; CURY ${ }^{170}$ (1996) avaliaram a concentração de flúor em 104 marcas de águas minerais comercializadas no Brasil. A utilização dessas águas tem sido grande e com importante aspecto em 
Literatura

relação ao consumo de flúor sistêmico. Embora essas águas fossem comercializadas amplamente em todo o Brasil, muitas também não apresentavam a concentração exata de flúor especificada nos seus rótulos, existindo quantidades de flúor variando de 0 a 4,4 ppm, apesar da maioria conter abaixo de 0,1 ppm. Os autores, da mesma forma, sugeriram que seria necessário um controle, pela Vigilância Sanitária, da quantidade de flúor presente nas águas minerais comercializadas no Brasil.

Esta mesma sugestão foi feita por BASTOS et al. ${ }^{14}$, em 2001, quando observaram variações de 0 a 0,46 ppm F, todas abaixo do teor "ótimo" considerado para a região, ao avaliar a concentração de flúor existente em vinte amostras de águas minerais de fontes naturais e nove amostras de águas minerais engarrafadas e comercializadas no mercado nacional, da região chamada de "Circuito das Águas SP” (Lindóia, Águas de Lindóia e Serra Negra).

Além da água, todas as fontes possíveis de flúor consumidas por crianças na faixa etária de risco devem ser avaliadas ${ }^{23,30,70,101}$, uma vez que o fator de risco mais importante é a quantidade total de flúor ingerido de todas as fontes durante o período crítico do desenvolvimento do esmalte $40,61,65,88,106,153,162$.

O leite é a primeira e a principal fonte de nutrição das crianças nos primeiros meses de vida, justamente quando os dentes anteriores estão em desenvolvimento. Por isso deve ser especialmente considerado em qualquer estudo que vise pesquisar a alimentação infantil ${ }^{23}$.

EKSTRAND et al. $^{44}$, em 1984, comentaram que quando bebês são amamentados (aleitamento natural), mesmo que as mães façam ingestão de água 
fluoretada, o risco de fluorose é mínimo, pois a concentração de flúor no leite humano é muito pequena, aproximadamente 0,005 a 0,01 ppm, sem que pareça existir alguma variação ao longo do dia ${ }^{64,96,129}$. O flúor é pobremente transportado do plasma para o leite.

A concentração de flúor no leite dos outros mamíferos também é baixa ${ }^{69,94}$, mas, pelo menos no caso do leite bovino, aumenta ligeiramente quando atinge os pontos de venda (devido à evaporação), onde se encontram concentrações de 0,03 a 0,06 ppm. Isto faz com que a ingestão de flúor por uma criança que ingere cerca de $150 \mathrm{~mL} / \mathrm{kg}$ massa corporal/dia de leite bovino seja em torno de 0,004 a 0,009 $\mathrm{mg} / \mathrm{kg}$ massa corporal/dia ${ }^{23,65}$.

O aleitamento de recém-nascidos com mamadeira é uma prática amplamente difundida em todo o mundo, e o bebê pode ser exposto a doses relativamente altas de flúor, contido na fórmula do leite e na água utilizada durante o seu preparo ${ }^{64}$. Na infância, as fórmulas são consideradas como a principal fonte de flúor, e estudos têm relacionado seu consumo ao risco de desenvolver fluorose, especialmente quando preparadas com água fluoretada $21,96,128,153,169$. As fórmulas de leite em pó preparadas com água fluoretada podem atingir níveis de flúor, em média, 50 vezes mais altos quando comparadas com o leite humano ${ }^{10}$.

O efeito da água fervida também merece atenção, visto que após a ebulição, com a evaporação, há maior concentração de flúor na água. Outros alimentos preparados com água de abastecimento fervida constituem também fontes importantes de flúor, como observados nas sopas, no arroz e no feijão ${ }^{10,94}$. 
O consumo de fórmulas infantis aumentou bastante nos últimos anos ${ }^{21,100}$. Elas podem estar disponíveis em três apresentações: pronta para consumo, líquidos concentrados, ou pós. No mercado brasileiro, em particular, a forma mais freqüente é a em pó. As concentrações de flúor nas fórmulas prontas para consumo são relativamente baixas, geralmente em torno de 0,1 a 0,3 ppm. As fórmulas líquidas concentradas têm em geral a mesma concentração de flúor das fórmulas prontas, mas deve ser adicionado, antes do consumo, o mesmo volume de água. Portanto, a concentração final de flúor dependerá da concentração presente na água usada para diluição. Já para as fórmulas em pó, a concentração média de flúor ocorre em torno de 0,69 ppm para os produtos à base de leite, sendo um pouco mais alta para os produtos à base de soja, devido ao maior nível endógeno de flúor no extrato da soja e à ligação do flúor ao fitato e ao fosfato tricálcio $20,21,64,89,96,110,153$. Para a reconstituição do produto, adiciona-se em média, $145 \mathrm{~g}$ de pó a $880 \mathrm{~mL}$ de água. Assim, a concentração final de flúor também dependerá daquela presente na água usada para diluição, ficando geralmente entre 0,276 e 0,980 ppm. Portanto, a ingestão de flúor por crianças que utilizam fórmulas infantis é maior que pelas que são amamentadas ${ }^{23,65,89,96,110,153 .}$

Para algumas fórmulas, essa ingestão chega a ser várias vezes maior ${ }^{23}$. Para crianças novas (até 2 meses), que consomem $170 \mathrm{~mL} / \mathrm{kg}$ massa corporal/dia de fórmula diluída em água contendo 1 ppm de flúor, a ingestão de flúor é de 0,102 e 0,167 mg/kg massa corporal/dia para as fórmulas líquidas concentradas e em pó, respectivamente. Para crianças com mais de 4 meses, que consomem em média $120 \mathrm{~mL} / \mathrm{kg}$ de massa corporal/dia de fórmula diluída, a ingestão de flúor fica em 0,072 e 0,118 mg/kg de massa corporal/dia, para as fórmulas líquidas concentradas 
e em pó, respectivamente. Ao considerar o limite de ingestão "segura" de flúor entre 0,05-0,07 mg/kg de massa corporal/dia, todos os valores estão acima do limiar sugerido para a fluorose nesses casos.

LARSEN et al. ${ }^{95}$ (1988) mostraram que em Narssaq (Groenlândia), crianças que consumiam leite em pó $(0,03$ a 0,16 ppm F) diluído em água contendo 1,1ppm F tinham maior prevalência de fluorose na dentição decídua que crianças moradoras em Vordinhborg (Dinamarca), que consumiam leite de vaca pasteurizado e água potável contendo 1,4 - 1,6 ppm F. A prevalência de fluorose nos primeiros molares permanentes, incisivos e caninos foi similar em ambas as cidades, enquanto que nos pré-molares foi maior em Vordinhborg, devido ao maior nível de flúor na água potável. Os padrões de fluorose espelham a exposição ao flúor durante a infância.

OSUJI et al. ${ }^{125}$ (1988) observaram em crianças canadenses que o uso prolongado de fórmulas (13 a 24 meses) estava associado com 3,5 vezes de risco de fluorose em dentes anteriores permanentes, comparado com o uso por menos tempo. Além disso, crianças que usavam dentifrícios fluoretados antes dos 25 meses de idade tinham, no entanto, um risco de fluorose 11 vezes maior em dentes anteriores permanentes. Os autores estimaram que a escovação precoce com dentifrícios fluoretados e o uso prolongado de fórmulas preparadas com água fluoretada foram responsáveis por $72 \%$ e $22 \%$ dos casos, respectivamente.

McKNIGHT-HANES et al. ${ }^{110}$ (1988) compararam a concentração de flúor presente em três fórmulas à base de leite e em quatro fórmulas à base de soja. Estas continham maiores níveis de flúor. As médias dos valores de flúor foram 0,30 $\mathrm{mg} / \mathrm{L}$ (fórmulas prontas para consumo); 0,24 mg/L (líquidos concentrados diluídos 
Literatura

com água deionizada); e $0,08 \mathrm{mg} / \mathrm{L}$ (pós concentrados diluídos com água deionizada). Ambas as fórmulas à base de soja prontas para consumo e líquidos concentrados forneceram doses diárias de flúor que, em combinação com suplementos dietéticos de flúor (0,25 mg F/dia), excederam a ingestão diária de flúor considerada "segura". As fórmulas à base de soja são a primeira indicação caso haja algum problema com o aleitamento ou de alergias alimentares.

LATIFAH; RAZAK $^{96}$ (1989) comentaram que bebês que consomem fórmulas e residem em áreas com água fluoretada têm maior ingestão de flúor total diariamente. As concentrações de flúor presentes nas fórmulas reconstituídas com água se aproximaram da concentração de flúor da água utilizada, fluoretada ou não. Há variações nas concentrações de flúor entre diferentes marcas comerciais de fórmulas como dentro da mesma marca obtida de diferentes locais, provavelmente relacionadas aos diferentes métodos de processamento e às diferentes áreas de obtenção da matéria prima e da água.

VAN WINKLE et al. ${ }^{169}$ (1995) verificaram que entre 78 águas engarrafadas disponíveis no comércio em lowa (EUA), os níveis de flúor variavam de 0,02 a 1,36 ppm (média de 0,18 ppm), sendo $83 \%$ de 0,02 a 0,16 ppm, $7 \%$ de 0,34 a 0,56 ppm, $1 \%$ tinha $0,88 \mathrm{ppm}$, e $9 \%$ mais que $1,0 \mathrm{ppm}$. Das 47 fórmulas à base de leite, 16 fórmulas prontas para consumo tinham níveis de 0,04 a 0,55 ppm de flúor (média de 0,17 ppm), 14 líquidos concentrados reconstituídos com água destilada tinham níveis de 0,04 a 0,19 ppm de flúor (média de 0,12 ppm), e 17 pós concentrados reconstituídos com água destilada tinham níveis de 0,05 a 0,28 ppm de flúor (média de $0,14 \mathrm{ppm}$ ). As 17 fórmulas à base de soja tinham uma faixa de 0,04 a 0,47 ppm 
de flúor (média mais elevada de 0,26 ppm). O tipo de fórmula e a água utilizada são fatores importantes a serem considerados.

SILVA; REYNOLDS ${ }^{153}$, em 1996, pesquisando fórmulas comumente consumidas na Austrália, calcularam que, se reconstituídas sem água fluoretada, variavam de 0,031 a 0,532 ppm. Porém, se reconstituídas com água contendo 1,0 ppm, proporcionariam uma quantidade de flúor 2 a 3 vezes superior a 0,07 mg F/kg massa corporal/dia.

No estudo de BUZALAF et al. ${ }^{21}$ (2001), o conteúdo de flúor de fórmulas em pó variou de 0,01 a 1,65 ppm, com uma grande dependência do conteúdo de flúor presente no diluente. A concentração de flúor variou de 0,01 a 0,75 ppm; de 0,91 a 1,65 e de 0,02 a 1,37 para fórmulas de leite preparadas com água deionizada, água potável fluoretada e águas minerais engarrafadas, respectivamente. Quando preparadas com água potável fluoretada, todas as marcas excederam o limite de recomendação diário de flúor. O maior valor foi obtido do leite de soja Nestogeno Soy, que para uma criança de 1 ano de idade, proporcionaria mais que duas vezes a ingestão de flúor diária recomendada. É preciso limitar a ingestão de flúor a quantidades inferiores que as associadas com o aumento do risco de fluorose, e evitar o uso de água potável fluoretada na preparação de fórmulas em pó.

Com o aumento da idade e da massa corporal da criança, a quantidade de flúor ingerido das fórmulas por quilo de massa corporal diminui. Entretanto, há que se considerar que as crianças, à medida que crescem e iniciam o desmame, já estão ingerido flúor a partir de outras fontes que não as fórmulas, a partir de papas e sucos, por exemplo $21,96,100,153$. Por outro lado, a biodisponibilidade do flúor a partir 
de fórmulas infantis à base de leite é de 65 a $72 \%$ e, deste modo, pode-se estar superestimando a absorção de flúor a partir de fórmulas infantis ${ }^{23,153}$. ERICSSON ${ }^{46}$ (1958) especulou que a coagulação gástrica das proteínas do leite com a subseqüente liberação do $\mathrm{Ca}^{2+}$ resultaria na formação de $\mathrm{CaF}_{2}$, assim reduzindo a absorção de flúor e elevando a excreção fecal. A biodisponibilidade do flúor de fórmulas à base de soja ainda não tem sido relatada.

As crianças consomem outros alimentos regularmente que, da mesma forma, devem ser considerados. A maioria dos alimentos tem concentração de flúor menor que 0,5 ppm $^{164}$, com exceção dos produtos à base de alguns peixes, como o salmão e a sardinha, de frutos do mar e de frango, que podem conter altos níveis, sendo que a inclusão de ossos, pele e conchas nesses produtos durante o processo de industrialização contribui muito para esses valores elevados ${ }^{23,71,94,172}$. Os produtos à base de frango podem conter de 0,6 a 10,5 ppm de flúor, segundo LEVY; KIRITSY; WARREN ${ }^{99}$ (1995) e HEILMAN et al. ${ }^{71}$ (1997). Entretanto, TRAUTNER; SIEBERT $^{166}$ (1986) observaram reduzida biodisponibilidade do flúor para a maioria dos produtos à base de carnes e peixes, provavelmente devido ao alto conteúdo de cálcio nesses alimentos.

Há que se considerar que os hábitos alimentares das crianças mudaram bastante nos últimos anos, tendo aumentado o consumo de alimentos e bebidas processados industrialmente, que podem ocultar quantidades significantes de flúor e contribuir para a quantidade total consumida diariamente $20,21,70,72,117,172$. Esses produtos dependem principalmente da concentração de flúor da água usada no seu processamento $^{19,20,59,64,72,88,100,148,168}$. 
Além disso, existe o "efeito halo", onde produtos manufaturados em regiões que contêm flúor na água de abastecimento difundem o mineral para populações que vivem em áreas com água fluoretada e não fluoretada $88,117,148,168$.

HARGREAVES $^{69}$ (1990) discutiu que produtos contendo flúor, como as bebidas carbonatadas fabricadas com água fluoretada, estão disponíveis em comunidades com baixos níveis de flúor na água de abastecimento. Dependendo da escolha individual de alimentos e bebidas, é possível que altos níveis de flúor sejam ingeridos se uma suplementação de flúor sistêmica também é prescrita. Ao menos que haja uma estreita avaliação da dieta individual, algumas crianças poderiam se colocar sob risco à fluorose.

O consumo de líquidos aumenta com a idade, em especial desde o nascimento até os 12 anos. Não obstante, demonstrou-se que durante esse período o consumo de água pode representar, no máximo, $50 \%$ da ingestão total de líquidos $^{114}$. PANG; PHILLIPS; BAWDEN ${ }^{128}$ (1992), estudando crianças de 2 a 10 anos, observaram que $40 \%$ de seu consumo de líquidos vinham da água e do leite, enquanto que $60 \%$ eram provenientes de outras bebidas.

VLACHOU; DRUMMOND; CURZON ${ }^{172}$ (1992), através do método de TAVES $^{163}$, avaliaram a concentração de flúor em 113 alimentos e bebidas para bebês no Reino Unido e encontraram grandes variações, conforme a classificação: laticínios mostraram valores entre 0,01 e 0,31 mg F/kg; produtos à base de carne, entre 0,04 e $0,72 \mathrm{mg} \mathrm{F} / \mathrm{kg}$; cereais, entre 0,04 e $0,7 \mathrm{mg} \mathrm{F} / \mathrm{kg}$; produtos à base de vegetais, entre 0,03 e 0,48 mg F/kg; frutas, entre 0,03 e 0,07 mg F/kg; sobremesas, 
entre 0,02 e 0,28 mg F/kg e bebidas, entre 0,01 e 0,51 mg F/kg. A ingestão de flúor pode variar conforme o produto consumido.

Variações nas concentrações de flúor também têm sido demonstradas entre diferentes marcas comerciais de alimentos e bebidas infantis, como dentro da mesma marca obtida de vários locais de fabricação e diferentes pontos de venda, conforme a água disponível e a forma de processamento industrial ${ }^{70,71,88,110}$, que dificultam a avaliação da concentração de flúor presente em cada produto ${ }^{169}$, ainda mais considerando que raramente os fabricantes mencionam os valores no rótulo ${ }^{72}$.

HEINTZE; BASTOS ${ }^{73}$ (1996) pesquisaram 61 bebidas diferentes quanto ao seu teor de flúor e $\mathrm{pH}$. As bebidas foram escolhidas entre as mais consumidas pelos brasileiros, como refrigerantes tipo cola, guaraná, limão e laranja, sucos, leite in natura e leite em pó, cervejas, águas minerais, chá mate e chá preto. Com exceção do chá preto (1,8 ppm F) e de uma água mineral com gás (Prata: 2,6 ppm F), todas as bebidas apresentaram concentrações de flúor abaixo de 1,0 ppm, a maioria delas abaixo de 0,4 ppm. Sucos, leite, chá mate e cinco amostras de águas minerais mostraram teores de flúor abaixo de $0,1 \mathrm{ppm}$. $\mathrm{O} \mathrm{pH}$ de todos os refrigerantes e sucos variou entre 2,5 e 3,4. Todas as outras bebidas tiveram $\mathrm{pH}$ acima de 4,0. As águas minerais tiveram pH próximo a 7,0. Para avaliar os benefícios e riscos do teor de flúor na alimentação, devem ser consideradas a quantidade e a freqüência dos alimentos ingeridos, assim como a biodisponibilidade. Em adição, deve-se considerar também outras fontes de flúor, além da dieta e da água, citando-se em primeiro lugar, os dentifrícios fluoretados. 
HEILMAN et al. ${ }^{71}$, em 1997, analisaram 206 alimentos infantis prontos para consumo e 32 cereais infantis secos, produzidos por duas companhias em lowa (EUA). As concentrações de flúor variaram de 0,01 a 8,38 ppm, com os maiores valores correspondendo aos alimentos contendo frango, que merecem consideração quando se determina a ingestão de flúor. Quase todos os produtos apresentaram menos que 0,6 ppm F. Para os cereais, o nível de flúor da água usada para o preparo pode ser um determinante mais importante para a ingestão de flúor que a própria concentração intrínseca do produto. Foi recomendada a monitoração contínua dos alimentos, especialmente daqueles contendo frango.

TURNER; CHAN; LI ${ }^{168}$ (1998) compararam a concentração de flúor presente em 24 refrigerantes e 22 sucos de frutas, obtidos em Houston - EUA (com água fluoretada) e em San Antonio - EUA (sem água fluoretada). Os resultados corresponderam à água utilizada durante o processamento. Todavia, quase $42 \%$ dos refrigerantes e alguns sucos obtidos em San Antonio mostraram o "efeito halo" com concentração maior de flúor, proveniente da fabricação em outras comunidades que tinham água fluoretada.

Em 1999, ROJAS-SANCHEZ et al. ${ }^{148}$, ao monitorarem a ingestão de flúor a partir da dieta e do dentifrício de 54 crianças de 16 a 40 meses de idade, divididas em 2 grupos sem água de abastecimento fluoretada (San Juan - Porto Rico; Connersville - Indiana) e 1 grupo com água de abastecimento fluoretada (Indianápolis - Indiana), observaram que a média de ingestão de flúor diariamente não era diferente estatisticamente entre os 3 grupos. A principal fonte de ingestão de flúor nos grupos sem água fluoretada foi o dentifrício fluoretado, e na cidade 
Literatura

fluoretada as crianças ingeriam tanto flúor do dentifrício como das bebidas. Vale ressaltar que nesta cidade fluoretada, foi observado que as crianças usavam menor quantidade de dentifrício por escovação e, por isso, mesmo com o consumo de bebidas com flúor, não houve diferença estatisticamente significante em comparação aos outros 2 grupos sem água fluoretada. Em San Juan, a ingestão média diária de flúor estava dentro da faixa de segurança estimada, no entanto, na cidade "halo" de Connersville (próxima à Indianápolis) e em Indianápolis, a ingestão diária de flúor tinha excedido essa faixa. Deve ser dada atenção ao risco de fluorose, independentemente da água de abastecimento ser fluoretada ou não.

HEILMAN et al. ${ }^{72}$ (1999) realizaram um estudo sobre os níveis de flúor em 332 refrigerantes, com resultados de 0,02 a 1,28 ppm, com média de 0,72 ppm. Os níveis de flúor excederam 0,6 ppm para $71 \%$ dos produtos. Os resultados variaram conforme o local de produção, mesmo dentro da mesma companhia e para o mesmo produto e não havia nenhuma diferença substancial entre aromas, entre refrigerantes convencionais e dietéticos, e entre tipos e tamanhos de embalagens. Os autores também relataram que nos EUA existe um consumo aumentado de bebidas (energéticos, refrigerantes, sucos prontos, etc.) que não sejam água e leite, e que as bebidas com maiores quantidades de flúor poderiam ser um adicional ao que já se tem na água de abastecimento, em dentifrícios e até em alimentos, propiciando um risco potencial ao aparecimento da fluorose. Geralmente os níveis de flúor presentes nos refrigerantes foram semelhantes àqueles das águas de abastecimento usadas para fabricação das referidas bebidas. 
PIN et al. ${ }^{135}$ (2000), ao avaliarem a concentração de flúor no leite, sucos, refrigerantes e alimentos infantis obtidos em Bauru - SP, se surpreenderam com teores de flúor na Coca-Cola "light" (Coca-Cola) e no Toddynho (Quaker) de 1,3 e 1,6 ppm, respectivamente, que são bebidas bastante consumidas pelas crianças no Brasil.

No mesmo ano, FIGLIOLIA et al. ${ }^{63}$ pesquisaram o flúor presente em sucos artificiais em pó também disponíveis comercialmente em Bauru - SP e encontraram valores entre 0,015 e 0,463 ppm $\mathrm{F}$, com os maiores valores referentes aos produtos com aromas de uva e laranja.

Dada a maior oferta de chás e alguns deles prontos para consumo, CURY ${ }^{30}$ (2001) discutiu que a quantidade de flúor nos chás de ervas e frutas não tinha qualquer significado com relação ao risco de fluorose, incluindo o chá-mate e o chimarrão, que são os mais consumidos no Brasil. Porém, no chá preto foi encontrada uma alta quantidade de flúor, cujo risco de fluorose dependeria da quantidade ingerida por dia. Apesar do chá preto não ser uma fonte de flúor expressiva no país, a indústria é capaz de mudar hábitos culturais. Dessa forma, o chá preto tendo o atrativo do "Ice Tea" pode passar a ser consumido. O chá pronto para consumo tipo preto chegou a apresentar 1,91 ppm $\mathrm{F}$, quantidade que se uma criança de $12 \mathrm{~kg}$ ingerisse uma lata/dia seria submetida a uma dose 2 vezes superior ao limite máximo em termos de fluorose clinicamente aceitável.

$\mathrm{Na}$ avaliação de BUZALAF et al. ${ }^{24}$ (2002), os autores encontraram que alguns cereais infantis vendidos no mercado brasileiro apresentavam concentrações de flúor maiores que esperados. Foi o caso do Mucilon e do Neston, ambos 
Literatura

produzidos pela Nestlé, que mostraram concentrações de 2,44 e 6,2 ppm. Principalmente o Mucilon é recomendado por alguns pediatras como um complemento alimentar a ser dado à criança, quando ela está sendo desmamada.

JACKSON et al. ${ }^{88}$ (2002) analisaram o conteúdo de flúor em 75 alimentos e bebidas industrializados, comprados em duas cidades do estado de Indiana (EUA): uma com água de abastecimento otimamente fluoretada (Richmond) e outra sem água de abastecimento fluoretada (Connersville). Exceto para amostras preparadas ou cozidas com água de abastecimento, o conteúdo de flúor dos alimentos e das bebidas era baixo, variando de 0,12 a $0,55 \mu \mathrm{F} / \mathrm{g}$, com nenhuma diferença estatisticamente significante na comparação entre amostras obtidas das duas cidades. Quando a água de abastecimento era usada para preparar, cozer ou reconstituir as amostras, o conteúdo de flúor dos alimentos e das bebidas era consideravelmente maior na cidade fluoretada de Richmond do que na cidade não fluoretada de Connersville.

ALMEIDA $^{1}$ (2002), após uma revisão da literatura sobre o teor de flúor em sólidos e líquidos disponíveis para o consumo infantil, concluiu que a ingestão de flúor através dos alimentos e das bebidas parece contribuir significantemente com a ingestão total de flúor, independente da água de abastecimento ser fluoretada ou não, e que somente a concentração de flúor presente nesta água não é suficiente para determinar a necessidade e a quantidade de suplementação de flúor. É, portanto, preciso que os profissionais analisem criteriosa e individualmente todas as fontes de ingestão de flúor, antes de recomendar a suplementação. 
Principalmente com o esforço de garantir o controle da cárie, o uso do flúor vem sendo disseminado também através de outras fontes alternativas, como suplementos dietéticos de flúor e outros produtos odontológicos com flúor.

Os suplementos dietéticos de flúor têm sido extensivamente estudados e identificados como fatores de risco para a fluorose em ambas as áreas fluoretadas e não fluoretadas ${ }^{17,85,99,130,134,148,161,171,174}$, embora sua contribuição para o aumento da prevalência da fluorose seja menor que a da água fluoretada e dos dentifrícios fluoretados, devido ao seu uso mais limitado e por menor período de tempo ${ }^{75,85,132,}$ 159.

Os protocolos de suplementação de flúor são baseados na concentração de flúor presente na água potável e na idade da criança ${ }^{2,20,171}$. Sua prescrição e uso em populações não expostas à água fluoretada são comuns, como uma substituição à fluoretação da água, com a justificativa de que essas populações consomem quantidades deficientes de flúor ${ }^{85,161}$. Porém, isto se torna inválido à medida que se observa um acentuado aumento da fluorose em populações não expostas à água fluoretada ${ }^{75}, 128,134,169,174$. A população, de modo global, está se aproximando do limite superior do consumo "seguro" de flúor ${ }^{19,99}$.

No entanto, há trabalhos que demonstram que os suplementos são prescritos inadequadamente a crianças que vivem em áreas fluoretadas ${ }^{85,93,131,157,160,167}$ e o risco de fluorose é quase 4 vezes maior que em áreas não fluoretadas ${ }^{106,141}$.

Os suplementos de flúor disponíveis são fluoreto de sódio, que podem ser encontrados sob diferentes formas comerciais, como tabletes, soluções aquosas (gotas) e comprimidos, associados ou não a vitaminas, e são vendidos livremente, 
sem necessidade de qualquer prescrição ${ }^{85}$. O flúor é administrado através de uma dose concentrada ou através de pequenos incrementos ao longo do dia. Da dose de suplemento ingerida pela criança, cerca de $95 \%$ do flúor é absorvido, e deste, $70 \%$ fica retido no organismo ${ }^{17}$.

As evidências epidemiológicas sugerem que a prevalência da cárie está em declínio, a prevalência de formas leves de fluorose está aumentando, o efeito cariostático do flúor é predominantemente tópico, e os suplementos dietéticos são fatores de risco à fluorose. Essas tendências e evidências científicas reforçam que é tempo de reavaliar o uso de tais suplementos ${ }^{85,86,161}$.

Associações entre fluorose e o uso precoce de suplementos fluoretados têm sido relatados da Suécia à Nova Zelândia ${ }^{37,78}$. Crianças suecas que consumiam tabletes de flúor por um período de pelo menos 12 meses a partir dos 6 meses de idade corriam um risco 5,4 vezes maior de desenvolver fluorose que crianças que não consumiam ${ }^{78}$.

DE LIEFDE; HERBISON ${ }^{37}$ (1989) observaram na Nova Zelândia, que crianças com história de uso contínuo de suplementos e crianças com história de algum uso de suplementos tinham maior prevalência de fluorose que crianças que consumiam água otimamente ou sub-otimamente fluoretada.

KUMAR et al. ${ }^{92}$ (1989), estudando fluorose e cárie em Newburg e Kingston (EUA), entre 1955 e 1986, sugeriram que o aumento da prevalência de fluorose na cidade não-fluoretada de Kingston ocorria devido ao uso de suplementos de flúor. A exposição ao flúor de outras fontes além da água ou de tabletes, porém, não foi avaliada. 
WOOLFOLK; FAJA; BAGRAMIAN ${ }^{185}$ (1989) também verificaram que suplementos fluoretados eram as únicas fontes auto-relatadas de exposição ao flúor que foram significantemente associadas à fluorose em áreas não-fluoretadas de Michigan (EUA).

PENDRYS; KATZ ${ }^{130}$ (1989) pesquisaram a exposição ao flúor em adolescentes residentes em Massachusetts e Connecticut (EUA). As formas de leve a moderada de fluorose foram fortemente associadas com a suplementação durante os primeiros 6 anos de vida e com a renda familiar média. Essas crianças tinham risco 28 vezes maior em comparação às crianças não expostas ao flúor nos grupos econômicos mais baixos. A suplementação do terceiro ao sexto ano de vida foi fator mais importante do que durante o primeiro ano de vida, suportando a teoria de que a fase de maturação da amelogênese é o período mais suscetível em comparação ao período de secreção.

ISMAIL; BANDEKAR ${ }^{86}$ (1999), ao realizar uma revisão sistemática da literatura (meta-análise), encontraram uma consistente e forte associação entre o uso de suplementos de flúor e a fluorose. O verificado aumento do risco era de pelo menos duas vezes. Nos estudos transversais ou casos-controle, a proporção de fluorose em usuários de suplementos variava entre 2,4 e 2,6 em comparação aos não-usuários. Nos estudos longitudinais, a variação era entre 5,5 e 12,2. Em comunidades não-fluoretadas, o uso de suplementos durante os primeiros 6 anos de vida estava associado com um significante aumento no risco de desenvolver fluorose. 
Muitos estudos questionaram que a prevalência e, em menor grau, a gravidade da fluorose, tinham aumentado na dentição permanente de crianças, desde que os protocolos de dosagens de suplementação de flúor tinham sido propostos em 1979 ${ }^{64,117}$. Assim, após um amplo estudo de revisão, recomendações mais atualizadas para a aplicação de suplementos foram propostas pela Council on Dental Therapeutics of the American Dental Association (ADA) e pelo Committee on Nutrition of the American Academy of Pediatrics (AAP), em abril de 1994. De acordo com o protocolo em uso, a dose recomendada continua a depender da concentração de flúor na água e da idade da criança. A diferença com o protocolo anterior está na redução da dose limite de 0,7 para 0,6 ppm $\mathrm{F}$, sendo, portanto, contra-indicada sua utilização quando a concentração de flúor na água apresentar valores superiores a 0,6 ppm F. No caso do Brasil, devido às altas temperaturas, o consumo de água é maior e talvez esse aspecto da recomendação devesse ser adaptado. Outro parâmetro modificado foi o início da suplementação, sendo indicada após os 6 meses de idade e não desde o nascimento. Com respeito à idade limite de uso deste método, foi modificada de 13 anos para até os 16 anos $^{171}$.

Quando a concentração de flúor na água for menor que 0,3 ppm, a criança de 6 meses até 3 anos pode receber $0,25 \mathrm{mg} \mathrm{F}$; de 3 a 6 anos, 0,5 mg F; e de 6 a 16 anos, 1,0 $\mathrm{mg} \mathrm{F}^{171}$.

Quando a concentração de flúor na água estiver entre 0,3 a 0,6 ppm, a criança de 6 meses até 3 anos não precisa receber suplementação; de 3 a 6 anos, $0,25 \mathrm{mg} F$; e de 6 a 16 anos, 0,5 mg $\mathrm{F}^{171}$. 
A dosagem indicada para a suplementação de flúor se aproxima justamente da quantidade total máxima de ingestão recomendada para limitar a fluorose. Isso permite pequena liberdade para a ingestão adicional de flúor da dieta e não permite a ingestão não-intencional de agentes tópicos de flúor ${ }^{117}, 118$. Há dificuldades em se definir a quantidade diária de flúor ingerida e conseqüentemente a dosagem complementar a ser administrada para atingir níveis "ótimos" para o benefício anticárie $^{17,101}$.

Profissionais de saúde têm maior responsabilidade pelo uso de suplementos, na somatória das fontes de flúor, pois os recomendam, sem observar a concentração deste elemento na água de abastecimento, nos dentifrícios, nas soluções para bochechos, entre outras fontes, e sem considerar a idade da criança. Os pais, por excesso de cuidado e orientação errônea, e os profissionais, por falta de atualização quanto à posologia correta na prescrição e a indicação equivocada, expõem a criança ao risco de fluorose ${ }^{17,79,157,167 .}$

Portanto, para reduzir o risco de fluorose, médicos e dentistas deveriam ser cautelosos quanto à prescrição de suplementos dietéticos de flúor para crianças em idade de risco. É importante que tenham conhecimento prévio da concentração de flúor a que a criança é submetida, de todas as fontes possíveis ${ }^{10,72,168,169}$, uma vez que várias fontes de flúor podem ser significantes para o desenvolvimento da fluorose, e que a ingestão total de flúor deveria ser considerada antes da recomendação de suplementos dietéticos de flúor $^{86,}{ }^{153}$. Na prescrição deve ser considerada a avaliação das necessidades individuais, com base nos conhecimentos atuais dos níveis de flúor já disponíveis, nas práticas de higiene 
bucal realizadas e na atividade de cárie ${ }^{86,96}$. E todos, homens e mulheres, médicos, dentistas, farmacêuticos, enfermeiros, higienistas e leigos, precisam ser educados e conscientizados para o uso apropriado do flúor $^{79}$.

Programas de suplementação via sistêmica, que estão sob controle individual deveriam ser desencorajados, desde que há evidências mostrando o baixo custobenefício em termos de saúde pública, além de que a inadequada ou excessiva cooperação da criança e da família pode resultar em uma extensa variedade de conseqüências, seja um pequeno ou nenhum efeito preventivo da cárie, ou a promoção da fluorose $e^{69,143}$.

Estudos recentes têm mostrado uma preocupação em determinar a existência de riscos de fluorose, ou não, com o uso de soluções para bochechos, de aplicação tópica de flúor e de dentifrícios fluoretados, nas concentrações habitualmente preconizadas, principalmente onde a água de abastecimento público é fluoretada ${ }^{8}$.

Os produtos odontológicos fluoretados contêm altas concentrações de flúor, variando de 230 ppm nas soluções para bochechos até 22.600 ppm nos vernizes fluoretados.

Os dentifrícios, que são os produtos odontológicos mais freqüentemente utilizados no Brasil, geralmente têm concentração de flúor entre 1000 e 1500 ppm, tanto na forma de fluoreto de sódio quanto na forma de monoflúorfosfato de sódio ${ }^{23}$, 97, 179 . Investigações vêm tentando quantificar o flúor ingerido por crianças durante a escovação, devido à falta de controle da deglutição, e qual é a freqüência de 
escovação, desde que a quantidade habitualmente deglutida e a freqüência contribuem para a quantidade total de flúor ingerida ${ }^{30,127,150}$ e o risco de fluorose.

Há estimativas de que crianças deglutem de 0,25 g a 0,5 g de dentifrício, correspondendo a 0,25-0,5 mg F a partir de um dentifrício de $1000 \mathrm{ppm}^{153}$. O flúor presente nos dentifrícios é rapidamente biodisponível, e os níveis no plasma aumentam bruscamente $e^{8,153}$.

A quantidade ingerida, que pode variar de 0 a $100 \%$, é inversamente relacionada à idade e diretamente relacionada à quantidade colocada na escova de dentes. Muitas crianças escovam seus dentes mais que uma vez por dia, e o uso do dentifrício e a ingestão de flúor apresentam muita variação. Desse modo, algumas crianças poderiam ingerir flúor em excesso somente do dentifrício, além do que é recomendado. Quando combinado com outras fontes regulares de flúor, como as anteriormente citadas, a quantidade de flúor ingerida aumenta, já que a ingestão é acumulativa, e maior é a porcentagem de crianças que estão acima da faixa "segura" de consumo de flúor ${ }^{101}$.

RIPA $^{144}$ (1991) estimou que, para uma criança menor que 6 anos de idade, a retenção média foi $27 \%$ da quantidade colocada na escova. Ao assumir o uso de 0,5 g de dentifrício à concentração de 1000 ppm $F$ por escovação, a média de retenção seria $0,134 \mathrm{mg} F$. Desde que a maioria das crianças escova 2 vezes por dia, isto contribuiria com $0,268 \mathrm{mg}$ da ingestão total de flúor. Similarmente, uma ingestão de 0,3 mg F de dentifrícios tem sido estimada para crianças de 2 anos de idade por NEWBRUN ${ }^{117}$, em 1992. 
Para CURY CU $^{30}$ (2001), do ponto de vista do uso coletivo de flúor em Odontologia no Brasil, a preocupação maior está na associação do uso de água fluoretada e dentifrícios fluoretados por crianças. Isoladamente, eles estão relacionados com níveis de fluorose que não despertam a atenção da população nem das autoridades sanitárias, por serem percebidos apenas pelo dentista. Considerando ser $0,07 \mathrm{mg} \mathrm{F} / \mathrm{kg}$ massa corporal/dia o limite em termos de fluorose clinicamente aceitável, resultados de estudos nacionais mostraram que em termos de média, não há preocupação quanto à ingestão de dentifrícios fluoretados, porém há grande variabilidade, o que preocupa em termos de indivíduo.

BUZALAF $^{23}$ (2002) considerou que a quantidade média de dentifrício aplicada na escova por crianças menores que 6 anos é $0,55 \mathrm{~g}$ por escovação. Se o dentifrício contém 1000 ppm de flúor, isto corresponde a uma exposição a 0,55 mg de flúor por escovação. Em média, 48\% desta quantidade são ingeridos por crianças de 2 a 3 anos, $42 \%$ por crianças de 4 anos e $34 \%$ por crianças de 5 anos, devido ao controle imaturo e inadequado da deglutição. Assumindo-se pesos corporais médios de 15, 18 e $20 \mathrm{~kg}$, respectivamente, a ingestão de flúor a partir de uma única escovação por dia resulta em uma ingestão de flúor de 0,018, 0,013 e 0,009 mg/kg massa corporal/dia, respectivamente. Assim, fica evidente que a escovação com dentifrício fluoretado aumenta significativamente a ingestão de flúor, particularmente para crianças de 2-3 anos e, obviamente, para aquelas que escovam os dentes 2 ou mais vezes ao dia.

No caso específico do Brasil, estudos conduzidos em crianças de 2-3 anos residentes em áreas com água fluoretada mostraram que as mesmas ingeriam em 
média 0,061 mg/kg massa corporal/dia de flúor (variação de 0,011 a 0,142) a partir do dentifrício ${ }^{127}$ e que o dentifrício contribuía com $55 \%$ da quantidade total de flúor ingerida diariamente ${ }^{103}$.

Para reduzir o risco de fluorose, é sugerido que o uso de dentifrícios com as maiores concentrações de flúor por crianças pré-escolares seja evitado. Somente pequenas quantidades devem ser colocadas na escova pelos pais ou com a supervisão deles. O desenvolvimento e a avaliação de dentifrícios com menores concentrações de flúor é uma alternativa que precisa ser estimulada. As embalagens dos dentifrícios podem apresentar um pequeno orifício que dispensem pequenas quantidades, para que a ingestão inadequada seja evitada ${ }^{15,16,19,27,28,30,97,98,144,171 .}$

É necessário cautela quando aromas especiais e/ou estratégias de "marketing" são utilizados, de modo que possam encorajar a ingestão de dentifrícios fluoretados. Contínuas considerações devem ser dadas para reduzir a concentração de flúor nos dentifrícios usados por crianças pequenas durante a fase em que estão em risco para o desenvolvimento da fluorose ${ }^{148}$. Programas de educação em saúde bucal devem abordar o risco de fluorose quando o flúor é usado de forma imprópria ${ }^{123}$.

Após realizar uma revisão da literatura, OLIVEIRA; AMARAL; PEREIRA ${ }^{123}$, em 2000, observaram uma questão bastante polêmica entre os profissionais, sobre se episódios isolados de ingestão de altas doses de flúor, como durante bochechos ou outras aplicações tópicas, poderiam provocar fluorose.

A principal preocupação deveria ser com aqueles produtos que são usados uma vez, duas vezes, ou três vezes por dia ou semanalmente, e particularmente 
aqueles que estão disponíveis no mercado livremente, sem supervisão ou orientação profissional quanto ao seu uso ${ }^{117}$.

As soluções para bochechos indicados para uso semanal contêm $\mathrm{NaF}$ a 0,2\% (quase 910 ppm F) e aquelas para uso diário contêm NaF a 0,05\% (quase 230 ppm F).

O Levantamento Nacional de Saúde dos EUA (NHIS) realizado em 1989 mostrou que $1 \%$ das crianças menores que 2 anos de idade e $9 \%$ daquelas de 2 a 4 anos usavam soluções para bochechos com flúor ${ }^{173}$.

A quantidade da solução ingerida após o bochecho também é variável, sendo inversamente relacionada à idade e à experiência de realizar bochechos, e diretamente relacionada à duração e ao volume usado ${ }^{144,177}$.

Embora as soluções fluoretadas para bochechos não sejam recomendadas para crianças pré-escolares dada a sua incapacidade de controlar os reflexos da deglutição das soluções ${ }^{177}$ e não sejam usadas rotineiramente, são comumente difundidas entre as crianças maiores nos EUA. Contudo, se mesmo uma pequena porcentagem de crianças na faixa etária de risco à fluorose participarem de programas de bochechos em jardins-de-infância e creches, significa que um certo número de crianças estará provavelmente ingerindo uma dose substancial de flúor $(1,0$ a $1,5 \mathrm{mg})$ em pelo menos de 20 a 30 ocasiões durante o ano ${ }^{101}$.

Ao considerar que a maioria das crianças é exposta aos bochechos com flúor em programas escolares aos 5 e 6 anos de idade, este fator geralmente é posterior à "janela de vulnerabilidade", para os dentes permanentes anteriores. Nesse caso, as 
soluções fluoretadas para bochechos não parecem ser um principal fator contribuinte ao risco de fluorose ${ }^{117}$.

LEVY; GUHA-CHOWDHURY ${ }^{101}$, em 1999, comentaram que a quantidade de flúor ingerida após uma aplicação tópica profissional de gel fluoretado (NaF a $1,23 \%$, equivalente a 12.300 ppm F) é variável, mas geralmente oscila de 10 a 35 mg F quando não é usado concomitantemente um aparelho de sucção, e de 2 a 7 mg $F$ quando é o aparelho de sucção é usado, com subseqüente expectoração. Estas quantidades de flúor ingerido excedem a "segura" ingestão de flúor. Mas, como essas aplicações não são freqüentes, geralmente sendo realizadas com intervalos entre 3 e 12 meses, a exposição a esses altos níveis não ocorre regularmente e ainda não está bem estabelecido se pode influenciar o risco à fluorose. No entanto, precauções devem ser adotadas para minimizar a ingestão de flúor, e a indicação deve se concentrar apenas para as crianças em atividade de cárie ou com maior risco para desenvolvê-la.

Se as orientações para a redução de ingestão de flúor durante a aplicação profissional forem seguidas, é improvável que o procedimento cause fluorose ${ }^{117}$.

HELLER; EKLUND; BURT $^{74}$ (1997) relataram que $56 \%$ da população dos EUA consomem água fluoretada, além de ser difundido o uso de comprimidos, géis, soluções para bochechos e dentifrícios fluoretados, e o consumo de alimentos e bebidas produzidos com água fluoretada. Observaram que todos os produtos com flúor acima citados têm um grau de influência na redução dos níveis de cáries assim como no aumento da prevalência da fluorose. Assumem que a pequena diferença entre a experiência de cárie nas áreas fluoretadas e não-fluoretadas não foi 
referente ao menor poder de ação da água de abastecimento fluoretada, e sim ao aumento do consumo de produtos fluoretados em ambas as áreas. A maior redução nos índices de cárie ocorreu na faixa de 0,7 ppm de flúor na água, enquanto poucos benefícios foram observados em níveis menores que estes. Neste estudo, o teor de flúor na água foi considerado um fator consistente e grandemente associado à prevalência e gravidade da fluorose, sendo mais observada em crianças menores. Entre os produtos fluoretados, somente os comprimidos com flúor foram considerados de grande associação à prevalência e/ou à gravidade da fluorose, principalmente administrados às crianças muito pequenas.

$\mathrm{Na}$ opinião de CURY $^{30}$, em 2001, enquanto a água fluoretada na concentração ótima é um método seguro, o mesmo não pode ser dito dos medicamentos fluoretados. Dos métodos tópicos, o dentifrício fluoretado está indiretamente envolvido, pois involuntariamente a criança o ingere toda vez que escova os dentes. Pensando que a fluorose ocorre em função da ingestão contínua, a aplicação tópica de flúor profissional não estaria relacionada em função da freqüência de utilização. Por outro lado, dependendo de como seria essa aplicação, uma quantidade grande poderia ser ingerida. Isto elevaria a concentração de flúor nos ossos, o qual seria subseqüentemente liberado afetando o esmalte em formação. As soluções fluoretadas para bochechos não estão relacionadas com a fluorose, porque somente estariam indicados após os 6 anos de idade, quando a criança tem melhor controle motor para expectorar. Entretanto, não é rara a descrição de bochechos com soluções fluoretadas por crianças de pequena idade, ainda sem indicação em termos de controle de cárie. Os materiais dentários liberadores de flúor não estão relacionados com o agravamento da fluorose, visto 
Literatura

que a quantidade liberada, por área de material, não atinge o nível sangüíneo de risco.

Nos vernizes fluoretados são encontrados 22.600 ppm F. São, portanto, produtos com alta concentração de flúor e que devem ser manipulados por profissionais qualificados, uma vez que seu emprego é indicado nos procedimentos de fluorterapia intensiva, preconizados para indivíduos de médio e alto risco à cárie. Porém, são considerados seguros, devido à rápida aderência sobre a superfície dentária, à lenta dissolução na cavidade bucal, à lenta liberação de flúor e à pequena quantidade requerida para a aplicação tópica ${ }^{171}$.

Embora muitos dos resultados das pesquisas científicas foram apresentados como valores médios de ingestão, a variação substancial acima ou abaixo da média deve ser considerada cuidadosamente quando se estuda a complexidade da ingestão de flúor ${ }^{97,98}$. Em adição, é difícil determinar a distribuição da ingestão total de flúor de múltiplas fontes e, com precisão, a contribuição relativa proporcional de cada uma dessas fontes sobre a população. No entanto, uma conclusão razoável é que muitas crianças estão ingerindo regularmente quantidades de flúor que, somadas, podem ser suficientes para elevar o risco à fluorose, e tentativas devem ser feitas para evitar essa ingestão excessiva de flúor ${ }^{23,101 .}$ 


\subsubsection{ABSORÇÃO}

O flúor se combina reversivelmente com íons hidrogênio para formar um ácido fraco, o ácido fluorídrico (HF), e muito do seu comportamento fisiológico pode ser explicado com base na difusibilidade do HF. Vários aspectos do metabolismo do flúor são pH-dependentes e a migração transmembrana do íon ocorre na forma de $H F$, em resposta às diferenças na acidez entre compartimentos adjacentes de fluidos corporais $^{10,180}$.

Depois que o flúor é ingerido, sua absorção é rápida e ocorre no trato gastrointestinal $^{112,121,181}$. O processo é passivo por natureza, no qual não parece intervir nenhum mecanismo ativo de transporte, não é afetado por alterações de temperatura ou inibidores metabólicos, e não ocorre contra um gradiente de concentração ${ }^{114,121,181 .}$

O flúor é prontamente absorvido no estômago, embora o esvaziamento gástrico para o intestino delgado limite a absorção total no estômago a aproximadamente $20-25 \%$ de uma determinada dose de flúor ${ }^{121}$.

A absorção pelo estômago está diretamente relacionada à sua acidez, ao conteúdo gástrico e à rapidez do esvaziamento gástrico para o intestino delgado. Portanto, quanto mais baixo for o $\mathrm{pH}$, a absorção ocorrerá mais rapidamente, e mais precoce será o pico de concentração nos fluidos corporais ${ }^{112,176,181}$. O flúor atravessa a mucosa gástrica predominantemente na forma de $\mathrm{HF}^{112}$. 
Além do $\mathrm{pH}$, a quantidade e a composição do alimento presente no estômago no momento da ingestão do flúor determinarão a quantidade e o índice de sua absorção. Isto é, tais fatores determinarão em que extensão o flúor estará biodisponível. Se o estômago já estiver preenchido com alimentos nos quais venha a se tornar firmemente confinado, ou já esteja, então, parte dele será excretada nas fezes e não será absorvida. Todavia, quando a maioria dos compostos de flúor é ingerida no estômago vazio, geralmente haverá completa absorção ${ }^{10,30}$.

EKSTRAND; EHRNEBO ${ }^{43}$ (1979) relataram que a biodisponibilidade da maioria dos preparos odontológicos fluoretados seria de $100 \%$, porém, se fossem ingeridos com produtos lácteos, que contêm cálcio, essa biodisponibilidade se reduziria até aos 60 a $70 \%$ aproximadamente.

Através de estudos laboratoriais com animais em jejum, o intestino delgado revelou ser o principal local de absorção. Enquanto o estômago é capaz de absorver rapidamente o flúor, a rapidez do esvaziamento gástrico limita sua contribuição à absorção total. Mesmo enquanto a maior parte da dose de flúor permanece no estômago, a maioria da absorção de flúor ocorre no intestino delgado. Inicialmente a absorção é maior no estômago a baixos valores de $\mathrm{pH}$, porém o aumento da absorção no intestino delgado compensa a menor absorção gástrica a altos valores de $\mathrm{pH}^{112,121}$.

O intestino delgado tem uma enorme capacidade de absorção de flúor. Estima-se que após 2 horas, seja responsável por $80 \%$ da absorção total ${ }^{112,121,181}$. Neste local, a absorção ocorre facilmente independente do alto $\mathrm{pH}$ do lúmen intestinal (que resulta em baixa concentração de HF), desde que não é afetada pelo 
$\mathrm{pH}$ e ocorre predominantemente na forma de íons flúor, que atravessam o epitélio intestinal via canais paracelulares das junções intercelulares ${ }^{111,121}$.

Talvez essa relação na absorção do flúor total pelo estômago e pelo intestino aconteça devido à maior proporção de íons flúor presente em comparação a de HF em pH fisiológico, que é de $10^{4}: 1^{111}$.

$\mathrm{Na}$ ausência de altas concentrações de certos cátions, como cálcio, magnésio e alumínio, que formam compostos insolúveis com o flúor, cerca de 80$90 \%$ de uma quantidade de flúor ingerida são absorvidas ${ }^{114,181}$. O meio tempo para absorção é cerca de 30 minutos $^{114,181,182}$.

\subsubsection{DISTRIBUIÇÃO E RETENÇÃO PELO CORPO}

Depois de absorvido, o flúor é rapidamente distribuído por todo o corpo. Os níveis plasmáticos geralmente começam a aumentar depois de 10 minutos, atingindo o pico após 20 a 60 minutos $^{180}$. A concentração neste pico depende da quantidade ingerida, da proporção de absorção, do volume de distribuição e das proporções de "clearance" do plasma pelos rins e pelo esqueleto ${ }^{3,}{ }^{182}$. O rápido declínio nas concentrações plasmáticas, que ocorre conforme a proporção de absorção diminui, é devido aos "clearances" renal e esquelético $23,58,114,178,181,182$.

WHITFORD $^{181}$, em 1997, afirmou que a fluorose dentária resulta de elevadas concentrações de flúor dentro ou nas proximidades do esmalte em desenvolvimento. Mas, como ainda não tem sido possível medir diretamente essas 
concentrações em subcompartimentos do esmalte em desenvolvimento, pesquisas têm se voltado ao estudo das concentrações no plasma sangüíneo. Estas são determinadas principalmente por dois fatores: quantidade ingerida e processos metabólicos responsáveis pela retenção ou eliminação do flúor ${ }^{180,}{ }^{181}$. De acordo com DENBESTEN ${ }^{40}$ (1999), esses fatores metabólicos são massa corporal, taxa de crescimento esquelético e períodos de remodelação óssea.

As concentrações de flúor intracelulares são de 10 a $50 \%$ mais baixas que aquelas presentes no plasma, mas mudam simultaneamente e na mesma proporção daquelas do plasma. Uma vez que o gradiente de $\mathrm{pH}$ entre os meios intra e extracelulares pode ser aumentado ou diminuído pela alteração do pH extracelular, é possível promover a entrada ou a saída de flúor nas células. Esta é a base para a sugestão de que a alcalinização dos fluidos corporais seja um bom coadjuvante no tratamento da toxicidade aguda pelo flúor ${ }^{23}$.

Quase todo o flúor do plasma encontra-se em forma de íons e não está combinado com nenhuma macromolécula ${ }^{114}$.

O nível da dose e a freqüência de ingestão determinam o maior ou menor estado de equilíbrio dos fluoretos no sangue, por isso, é possível prever logicamente que níveis de flúor no plasma de indivíduos que vivem em zonas com diferentes concentrações na água potável mostram estados de equilíbrio também diferentes.

A concentração de flúor na maior parte dos tecidos moles é inferior ao seu nível no plasma, salvo nos rins sadios, nos quais pode se produzir um acúmulo ocasional de flúor devido à produção de urina ${ }^{184}$. 
Aproximadamente $99 \%$ do flúor retido no organismo estão associados aos tecidos mineralizados, devido à afinidade existente entre os íons flúor e a hidroxiapatita, principalmente ao osso, mas também ao esmalte e à dentina ${ }^{182}$. A maioria desse flúor está fortemente, mas não irreversivelmente, ligado. A concentração de flúor de todo o esmalte reflete o nível de exposição durante a formação dos dentes, enquanto que as concentrações presentes na dentina e no osso são geralmente proporcionais à ingestão ao longo do tempo ${ }^{179}$.

O grau de assimilação do flúor nos ossos e dentes dependerá das quantidades ingeridas e absorvidas, e da duração da exposição aos fluoretos, da classe, localização e atividade metabólica do tecido em observação, e da idade do indivíduo ${ }^{5,182}$.

Observou-se um fenômeno interessante em indivíduos residentes em zonas cuja água potável continha um nível bastante elevado de flúor e, a seguir, passaram a residir em zona deficiente do mineral. A excreção urinária de flúor manteve-se elevada durante um tempo considerável apesar de haver diminuído notavelmente sua ingestão diária. Este modelo de excreção reflete uma liberação de flúor pelos ossos, que se manterá até que se alcance um novo equilíbrio do composto. Esse equilíbrio ou nível estacionário aparente também pode ser observado no plasma. Depois de haver-se ingerido muito flúor durante um longo período de tempo, observa-se uma estreita relação entre seu grau de concentração no plasma e seu nível nos ossos.

Este aspecto é importante ao considerar os trabalhos laboratoriais de ANGMAR-MÅNSSON et al. ${ }^{3,4,5}$ (1976, 1982, 1984), que sugeriram que distúrbios 
na mineralização do esmalte poderiam ocorrer também na ausência de elevados níveis de flúor no sangue. Os autores verificaram em ratos que picos transitórios de $10 \mu \mathrm{M}$ de flúor, administrados através de injeções, somente durante 7 dias, causaram alterações na mineralização da matriz do esmalte, semelhantes àquelas provocadas por doses crônicas bem menores de flúor $(3,1 \mu \mathrm{M})$. A partir desses trabalhos pôde-se sugerir que a dosagem de flúor plasmática não é mandatária na constatação de fluorose dentária. Além disso, no entanto, ANGMAR-MÅNSSON; WHITFORD ${ }^{6}$, em 1985, observaram que seria possível manter concentrações de flúor nas proximidades do esmalte em desenvolvimento, suficientes para causar fluorose, mesmo na ausência de concentrações sistêmicas elevadas, baseados na hipótese de que a mobilização, à longo prazo, de flúor do osso que comporta o dente em desenvolvimento proporcionaria uma dose, que poderia elevar as concentrações próximas ao esmalte e afetar a amelogênese negativamente. Esta hipótese foi confirmada pelo estudo de ANGMAR-MANSSON; LINDH; WHITFORD", publicado em 1990.

Apesar desses estudos serem realizados em ratos, os resultados são válidos, desde que se aceita que esses animais se mostram como um bom modelo experimental $^{4}, 113,137$, devido à sua suscetibilidade aos efeitos do flúor na odontogênese e na amelogênese em especial ${ }^{156}$. Em ratos, as concentrações de flúor no plasma associadas à fluorose são de mesma magnitude daquelas que podem ocorrer em humanos ${ }^{139}$.

Assim, a dose, o momento de exposição precoce ao flúor e a duração da exposição são importantes fatores relacionados com a prevalência e a gravidade da 
fluorose $^{3,}$ 5, 38, 39, 40. PENDRYS; STAMM ${ }^{132}$ (1990) também sugeriram que a exposição precoce ao flúor poderia proporcionar elevados níveis de flúor nos ossos, que, como um reservatório de flúor, mais tarde disponibilizaria os íons via remodelação óssea. Embora o estádio inicial da maturação seja mais sensível aos efeitos do flúor $39,40,77,137,147,181$, a fluorose é mais grave quando a exposição ocorre em ambos, no de secreção e no de maturação, devido à maior dose de flúor acumulada pelo maior tempo de exposição e maior biodisponibilidade ${ }^{40}$.

DENBESTEN ${ }^{39}$, em 1994, comentou que em uma população, há uma relação direta entre o grau de fluorose dentária, níveis de flúor no plasma e nos ossos, e a concentração de flúor na água potável. Considerando uma resposta individual à exposição ao flúor, fatores como a massa corporal, nível de atividade (que determinaria a ingestão de água fluoretada), fatores nutricionais, "clearance" renal e taxa de crescimento e remodelação óssea são também importantes.

O "clearance" do flúor do plasma pelo esqueleto ocorre rapidamente. Aproximadamente $50 \%$ do flúor absorvido diariamente por jovens ou adultos saudáveis de meia-idade se associa aos tecidos calcificados em 24 horas, enquanto que quase todo o restante é excretado pela urina. Esta distribuição 50:50 se desloca a favor de maior retenção em bebês e $\operatorname{crianças~}^{180,182}$, e provavelmente se desloca a favor de uma maior excreção em indivíduos mais velhos, embora se saiba pouco sobre esse assunto. $O$ aumento da retenção de flúor pelo esqueleto em desenvolvimento parece ser devido quase que inteiramente ao rico suprimento sangüíneo e à maior área de superfície dos cristalitos ósseos, que são menores, 
mais desorganizados e mais numerosos, quando comparados ao osso maduro ${ }^{40,}$ 180, 182

WHITFORD $^{181}$, em 1997, simplificou relatando que o aumento na prevalência da fluorose indica que a ingestão e a retenção de flúor pela criança no período de risco têm aumentado significantemente.

Apenas recentemente, a utilização de marcadores biológicos ou biomarcadores para flúor tem sido discutida para o estudo da fluorose, apesar das dificuldades relacionadas ao fato de que vários fatores podem afetar o modo de como os indivíduos respondem a uma mesma dose de flúor. São exemplos de biomarcadores, a ocorrência de fluorose (biomarcador de efeito), distúrbios sistêmicos, ambientais e genéticos (biomarcadores de susceptibilidade) e plasma sangüíneo, cabelo e unhas (biomarcadores de exposição) ${ }^{23}$.

BUZALAF et al. ${ }^{22}$, em 2002, apresentaram resultados de seus estudos para avaliar a viabilidade de se usar unhas como indicadores da exposição ao flúor em ratos. Os autores observaram uma relação direta entre a ingestão crônica de flúor e a sua concentração no plasma e nas unhas, como já havia sido demonstrado em humanos, e que o rato é um bom modelo experimental para esses estudos. 


\subsubsection{EXCREÇÃO}

O rim é a via principal de excreção do flúor ${ }^{23,114,181 .}$

Na excreção renal, após a filtração glomerular, quantidades variáveis de flúor são reabsorvidas nos túbulos proximais e distais pelo mecanismo de difusão passiva simples.

$\mathrm{Na}$ regulação do processo de eliminação, intervém tanto o fluxo urinário quanto o $\mathrm{pH}^{181,182}$. Assim, um fluxo urinário rápido e uma urina alcalina darão lugar à eliminação rápida de flúor, enquanto que a lentidão do fluxo urinário e a acidez da urina produzirão uma eliminação renal mais lenta e reabsorção e retenção de flúor.

Já em 1972, JUNCOS; DONADIO ${ }^{90}$ comentavam que o flúor parecia ser prontamente filtrado pelos rins, mas não prontamente secretado pelos túbulos renais. Em adição, anteciparam que a rápida excreção urinária seria um importante mecanismo através do qual o organismo preveniria o acúmulo de flúor a níveis tóxicos. Em pessoas com funções renais normais, a freqüência de fluorose deveria ser insignificante, a menos que a ingestão de flúor fosse excessiva. Os autores também relataram que o flúor poderia ser retido e causar fluorose, especialmente em pacientes com insuficiência renal, como ressaltado através da descrição de casos clínicos de dois pacientes que apresentavam fluorose, provavelmente relacionado à diminuição da função renal, à exposição elevada ao flúor da água, e à polidipsia secundária à poliúria. 
IRIGOYEN; MOLINA; LUENGAS ${ }^{81}$, em 1995, observaram que a elevada altitude e a acidose e seus efeitos sobre o $\mathrm{pH}$ urinário podem contribuir para o alto índice de fluorose.

LARA; GRANJEIRO ${ }^{94}$ (1998) comentaram que o uso de drogas acidificantes (diuréticos), doenças como diabete mellitus, acidose tubular renal e doença pulmonar crônica, e o consumo de dieta altamente proteica (carne), podem alterar o pH urinário, e desse modo, afetar a retenção, a concentração tecidual e os efeitos do flúor.

O rim é que regula, em curto prazo, o metabolismo geral do flúor no organismo. O osso, por sua vez, é o órgão correspondente para a regulação a longo $\operatorname{prazo}^{58}$

\subsection{PERÍODO DE RISCO AO DESENVOLVIMENTO DA FLUOROSE DENTÁRIA}

É importante que se entenda porque um indivíduo pode estar correndo o risco de desenvolver a fluorose dentária e em qual período isso pode ocorrer.

Uma boa explicação foi dada por DENBESTEN ${ }^{40}$ (1994), ao sintetizar que a fluorose é um reflexo da exposição ao flúor, somente durante o tempo da amelogênese. 
Apesar de seu caráter irreversível, pode ser prevenida se a ingestão de flúor for adequadamente controlada durante o período da formação dentária ${ }^{13}$.

A fluorose pode ocorrer posteriormente à exposição aguda e/ou crônica ao flúor $^{38,153}$. É caracterizada pela retenção das amelogeninas na fase inicial do estádio da maturação e a formação de um esmalte mais poroso com uma hipomineralização subsuperficial. Acredita-se que o estádio de secreção da amelogênese seja mais suscetível à exposição aguda ao flúor e o estádio de transição / fase inicial do estádio da maturação seja mais suscetível à exposição crônica acima dos níveis de segurança. O risco de fluorose é menor quando a exposição ocorre somente durante o estádio de secreção, mas é maior quando a exposição ocorre em ambos os estádios de secreção e maturação ${ }^{40}$.

Após realizar uma sistemática revisão da literatura (1966-98) sobre os períodos de risco associados à fluorose nos incisivos centrais superiores permanentes, BÅRDSEN ${ }^{13}$ (1999) considerou que não havia nenhum período específico da amelogênese que pudesse ser isoladamente escolhido como o mais crítico para o desenvolvimento da fluorose. A duração da exposição ao flúor durante a amelogênese foi um fator importante para explicar o desenvolvimento da fluorose.

Os efeitos da ingestão de flúor parecem ser acumulativos durante a formação dentária ${ }^{38,78}$.

HOLM; ANDERSSOM ${ }^{78}$ (1982) verificaram que a prevalência da fluorose entre crianças que tinham iniciado suplementação com tabletes de flúor aos 6 meses de idade era de $81 \%$, comparadas com prevalências de 59, 38 e 33\% para crianças que iniciaram suplementação aos 12, 24 e 36 meses de idade respectivamente. 
Ao registrarem o grau de fluorose em crianças submetidas a uma dose inicial de 7,8 ppm de flúor na água potável, que foi subseqüentemente alterada a 0,2 ppm, ISHII; SUCKLING ${ }^{82}$ (1986) encontraram fluorose de graus moderado a severo em incisivos centrais superiores de crianças com idades entre 35 a 42 meses no momento da mudança de concentração, quando os dentes estavam na fase de maturação do esmalte. Ao contrário, crianças com 11 a 33 meses (fase de secreção) tinham ou fluorose muito leve, questionável, ou nenhum sinal de fluorose. Outros estudos epidemiológicos também suportam os achados experimentais de que os estádios de transição, e principalmente, de maturação da formação do esmalte são mais suscetíveis aos efeitos do flúor ${ }^{19}, 38,48,49,83,132$.

O início e a duração do período de mineralização do esmalte variam entre os diferentes grupos de dentes, deste modo pode-se esperar que o período de maior suscetibilidade possa variar de acordo com eles. Para simplificar a avaliação dos períodos de risco, alguns estudos restringiram-se aos incisivos centrais superiores permanentes, que são dentes com adicional importância estética ${ }^{13,47,49,83}$.

EVANS; STAMM ${ }^{47}$ discutiram em 1991, que um aumento no grau de fluorose em momentos específicos da formação do esmalte revelou que os incisivos centrais superiores eram mais suscetíveis à fluorose durante o período dos 22 aos 26 meses de idade.

Na mesma publicação de 1994, sobre o uso da fluorose como um biomarcador, DENBESTEN ${ }^{39}$ citou que a mineralização detectável radiograficamente dos incisivos permanentes ocorre aos 24 meses de idade e antes dos 6 anos para 
os segundos molares e pré-molares. Portanto, a fluorose não acontece quando a exposição ocorre em crianças maiores que 6 a 7 anos de idade.

FEJERSKOV et al. ${ }^{58}$, em 1994, relataram que o período de risco cobria o tempo desde o nascimento até a erupção do último dente (um período de aproximadamente 20 anos). Pois, após a espessura completa do esmalte de um dente ter sido formada pelos ameloblastos, o esmalte continua a adquirir fluidos minerais dos tecidos adjacentes até um pouco antes da erupção dos dentes. Aproximadamente 30 - 40\% da deposição mineral na metade externa do esmalte ocorreria durante essa fase.

Com o objetivo de realizar uma estimativa mais apurada do período crítico de suscetibilidade à fluorose de incisivos centrais superiores humanos, EVANS; DARVELL ${ }^{49}$ examinaram 1.085 crianças chinesas de Hong Kong, com idades entre 7 e 12 anos, agrupadas por meses de idade em relação ao mês de junho de 1978, quando houve redução de flúor na água de abastecimento público de 1,0 para 0,7 ppm, e publicaram, em 1995, que esses dentes, no todo, apresentavam risco maior à fluorose entre os 15 e 20 meses de idade para o sexo masculino e entre os 21 e 30 meses para o sexo feminino. O pico de correlação do escore de fluorose versus a concentração de flúor para o terço incisal ocorreu aos 17,5 meses de idade para o sexo masculino, e 6 meses mais tarde para o sexo feminino. O período crítico para exposição ao flúor estendeu-se por quase 4 meses de duração para cada terço do dente. Quanto à diferença entre os sexos, geralmente é aceito que o desenvolvimento humano aconteça mais precocemente para o sexo feminino, no entanto, a literatura em relação ao desenvolvimento dos incisivos centrais superiores 
é polêmica neste ponto. NOLLA ${ }^{120}$ (1960) relatou que a época da formação completa da coroa destes dentes era 54 meses para ambos os sexos. Para todos os outros grupos de dentes, as coroas eram formadas mais cedo para as meninas. FANNING $^{50}$ (1961) encontrou que era 59 e 64 meses para meninas e meninos respectivamente. NIELSEN; RAVN $^{119}$ (1976) observaram que a mineralização ocorria antes nas meninas, exceto para os incisivos centrais superiores.

Desde que o flúor parece afetar especialmente a fase final da secreção e o início da maturação do esmalte, a ingestão excessiva de flúor seria de maior preocupação durante os primeiros sete anos de vida, na opinião de SILVA; REYNOLDS $^{153}$, em 1996.

WHITFORD $^{181}$ (1997) se restringiu a enfatizar que os dentes permanentes anteriores, que são de maior importância estética, estão expostos ao maior risco para fluorose durante um período de dois anos, que se estende do $2^{\circ}$. ao $3^{\circ}$. ano de vida pós-natal.

CURY $^{30}$, em 2001, considerou que haveria risco de desenvolvimento de fluorose durante toda a formação do esmalte, mesmo nos períodos de mineralização mais tardia. Por outro lado, considerando-se que esteticamente os dentes mais comprometidos seriam os incisivos centrais superiores, a faixa etária de 20 a 36 meses seria considerada crítica em termos de ingestão de flúor.

Quanto mais tarde no período de pré-erupção, um dente for exposto ao flúor, menor será o nível de gravidade da fluorose resultante. 


\subsection{DOSE "SEGURA" DE EXPOSIÇÃO AO FLÚOR}

Há uma certa concordância na literatura que para evitar um grau indesejável de fluorose, a ingestão diária de flúor pela criança definitivamente não deveria exceder $0,1 \mathrm{mg} / \mathrm{kg}$ massa corporal ${ }^{101}$. Este valor limite ("threshold") de ingestão sobre o qual a fluorose ocorre, foi derivado dos estudos de MCCLURE $^{107}$ sobre os níveis de consumo de flúor a partir de alimentos e bebidas (incluindo a água) por crianças em 1943, quando dentifrícios, soluções para bochechos, géis e suplementos fluoretados não estavam disponíveis. Usando avaliações grosseiras do tipo e da quantidade de alimentos e bebidas consumidos e técnicas menos sensíveis, McClure estimou que crianças de 1 a 12 anos de idade, moradoras de áreas fluoretadas $(1,0 \mathrm{ppm})$ recebiam 0,103-0,16 $\mathrm{mg} \mathrm{F} / \mathrm{kg}$ massa corporal apenas de alimentos e de água, e que essa ingestão raramente excedia $0,1 \mathrm{mg} / \mathrm{kg}$ massa corporal. Nestes níveis de ingestão de flúor da dieta e na ausência de qualquer outra fonte importante de flúor, como dentifrícios e suplementos fluoretados, aproximadamente $7-16 \%$ de fluorose muito leve ou leve foi observado naquele tempo.

Baseados nestas observações, aceita-se que uma ingestão diária de flúor acima de 0,1 mg/kg massa corporal freqüentemente causa fluorose, e níveis de ingestão de 0,05-0,07 mg/kg massa corporal são citados na literatura como sendo “ótimo" para a saúde dentária em crianças de 1 a 12 anos de idade ${ }^{51,66,124}$.

BURT $^{19}$ (1992) revisou a história do termo "ingestão ótima de flúor". Ao pesquisar como a informação de McClure em 1943 veio a ser interpretada como 
recomendação por outros pesquisadores ${ }^{51,66,}{ }^{124}$, observou que FARKAS; FARKAS $^{51}$ tinham citado um número de opiniões pessoais, muitas das quais não tinham credibilidade. Depois, OPHAUG et al. ${ }^{124}$ tinham citado FARKAS; FARKAS $^{51}$, e FORRESTER; SCHULZ ${ }^{66}$. E estes tinham citado uma fonte cuja referência não era dada. Baseado em um artigo de EKSTRAND ${ }^{45}$ (1989), BURT ${ }^{19}$ estimou que o limite superior de ingestão de flúor por crianças pequenas deveria ser aproximadamente de $0,05 \mathrm{mg} / 100 \mathrm{kcal}$. Suas estimativas corresponderam-se bem com a faixa de "ingestão ótima de flúor" por crianças relatada por outros pesquisadores $^{70,107,124}$. E concluiu que, "apesar de sua gênese dúbia, evidências empíricas sugeriram que 0,05-0,07 mg F/kg massa corporal/dia continuava a ser um limite útil para a ingestão de flúor de todas as fontes pelas crianças". Todas as fontes representam fontes dietéticas e não dietéticas combinadas.

A maior dificuldade que se enfrenta para estimar qual dosagem diária de flúor pode resultar em fluorose é, naturalmente, que o efeito não se manifesta clinicamente a curto prazo $^{77}$. Portanto, qualquer estimativa de dosagem diária de flúor associada à fluorose é apenas um número aproximado ${ }^{117}$.

Não existe nenhum limite distinto de concentração de flúor, abaixo do qual a fluorose não se manifestará ${ }^{58,}{ }^{148}$. Diversos fatores podem influenciar a suscetibilidade dos indivíduos ao flúor ${ }^{77}$.

Em 1986, a ACADEMIA AMERICANA DE PEDIATRIA ${ }^{2}$ consentiu que para evitar o risco de desenvolver fluorose, a ingestão total de flúor não deveria exceder $0,1 \mathrm{mg} / \mathrm{kg}$ massa corporal/dia. 
BAELUM et al. ${ }^{12}$ (1987) e FEJERSKOV et al. ${ }^{54}$ (1987) apontaram um nível surpreendentemente baixo de 0,03 a $0,04 \mathrm{mg} \mathrm{F} / \mathrm{kg}$ massa corporal/dia para a ingestão segura de flúor. Essa quantidade está muito abaixo da que geralmente é mencionada na literatura.

As estimativas devem ser interpretadas com cuidado por inúmeras razões. A ingestão de flúor ocorre durante um longo período durante o qual as crianças crescem rapidamente e a sua dieta muda substancialmente. Assim, sua ingestão de flúor em relação ao peso do corpo variará marcadamente em épocas diferentes, durante o período de formação dos dentes. Além disso, embora se possa estimar as dosagens da concentração de flúor na água potável ou dos comprimidos, existem muitas outras fontes que podem aumentar a ingestão total de flúor: dentifrícios, outros agentes tópicos, ou até alguns componentes da dieta, e é impossível estimar a contribuição de cada uma dessas fontes. Qualquer que seja a fonte de flúor na dieta, deve-se ter em mente que as estimativas de ingestão não são necessariamente equivalentes ao real acúmulo de flúor no corpo, visto que a biodisponibilidade do flúor ingerido pode determinar quanto realmente foi absorvido pelo corpo.

Para NEWBRUN ${ }^{117}$ (1992), cronologicamente, a "janela de vulnerabilidade" à fluorose envolvendo os dentes permanentes anteriores situa-se desde o nascimento até os 6 anos de idade. Portanto, é a dosagem durante este período que necessita ser mais cuidadosamente estabelecida. A dosagem de suplementos de flúor com base na massa corporal da criança seria mais apropriada do que a com base em sua idade. Os valores apontados na literatura são geralmente dados 
Literatura

aproximados, baseados em suposições mesmo que sobre testes clínicos cuidadosamente controlados.

SILVA; REYNOLDS ${ }^{153}$ (1996) concordaram que, embora empiricamente determinada, a ingestão total de flúor diariamente de 0,05-0,07 $\mathrm{mg} \mathrm{F} / \mathrm{kg}$ massa corporal em crianças abaixo de 12 anos de idade é geralmente considerada "ótima" para beneficiar a saúde dentária. E também admitiram que, para evitar um grau indesejável de fluorose, a ingestão total de flúor por dia não deveria exceder $0,10 \mathrm{mg}$ F/kg massa corporal.

CURY $^{30}$ (2001), considerando ser necessária ou inevitável, assumiu que 0,05 a 0,07 mg F/kg massa corporal/dia deve ser o limite máximo a que uma criança pode ser submetida, para garantir que essa fluorose não atinja um grau que comprometa a estética dentária.

Todas as formas de ingestão de flúor devem ser pesquisadas. Em muitas partes do mundo, até mesmo os níveis mais recomendados de fluoretação das águas de abastecimento público de $1 \mathrm{ppm}$, ou até mesmo 0,7 ppm, resultaram em níveis de fluorose preocupantes ${ }^{129}$.

Deste modo, pode-se afirmar que o nível "ótimo" de ingestão sistêmica de flúor adequado para o controle da cárie dentária e "seguro", incapaz de produzir lesões de fluorose, ainda não é precisamente conhecido, mas, quando se pretende estimar esse valor, todas as fontes de flúor, sem exceção, devem ser consideradas. É vital que todas as condições locais que possam contribuir para níveis inesperadamente altos de fluorose sejam cuidadosamente examinadas ${ }^{30}$. 
A faixa de 0,05 a $0,07 \mathrm{mg}$ de flúor/kg massa corporal/dia parece ser um

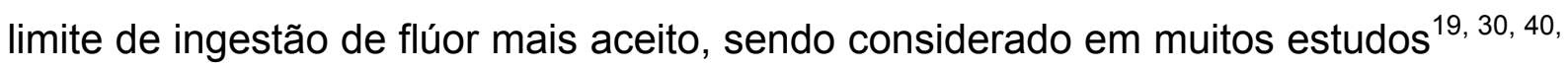
$70,71,96,98,100,101,110,123,135,148,153$.

\subsection{CONSUMO DE MEDICAMENTOS PEDIÁTRICOS POR PROBLEMAS DE SAÚDE CRÔNICOS}

A incidência de doenças crônicas em crianças tem sido relativamente estável nas últimas décadas. Devido ao diagnóstico precoce e tratamentos médicos mais eficazes, um número crescente de crianças com doenças crônicas sobrevivem. Em condições tais como atresia biliar, fibrose cística, síndrome de Down e leucemia linfoblástica aguda, tem ocorrido uma grande elevação da expectativa e da qualidade de vida ${ }^{91}$.

Crianças com alergias alimentares ou com intolerância à lactose podem estar expostas a maior ingestão de flúor a partir de fórmulas à base de soja, uma vez que estas são a primeira indicação nesses casos, em substituição ao leite de vaca $^{110}$. Em situação semelhante estão as crianças sob tratamento quimio ou radioterápico contra o câncer, pois fórmulas à base de soja são prescritas para consumo durante todo o tratamento.

Por outro lado as condições médicas também necessitam de terapia medicamentosa diariamente por longo tempo ${ }^{41,53,76,145}$. Crianças com problemas 
Literatura

alérgicos, asmas, bronquites, rinites e dermatites atópicas utilizam rotineiramente anti-histamínicos e broncodilatadores. Há aquelas crianças com problemas hepáticos, reumáticos, oncológicos e deficiências auto-imunes, que necessitam de terapia com corticosteróides regularmente. Pacientes renais, com distúrbios de refluxo vesicouretal e processos infecciosos do trato urinário, recorrem a quimioprofiláticos antibióticos, sulfas e nitrofurantoínas. Extensos tratamentos com antibióticos são freqüentemente prescritos para crianças com otite média recorrente ou febre reumática. Pacientes com problemas cardíacos consomem diariamente medicamentos conhecidos como digitais. Nos casos de epilepsia, ingerem doses regulares de anticonvulsivantes. No quadro anêmico, complexos ferrosos e vitamínicos são prescritos por 6 meses, no mínimo. Sem contar as crianças que constantemente fazem uso de analgésicos, antiinflamatórios, expectorantes e antiespasmódicos ${ }^{41,53,146}$.

A maioria dos medicamentos pediátricos é prescrita na forma líquida. Os ingredientes ativos desses medicamentos são fundamentais para a melhora e a manutenção das condições de saúde da criança, porém outros ingredientes podem ser perigosos, com efeitos indesejáveis ${ }^{52,53}$. Evidências acumuladas, com base clínica e experimental, mostram uma significante associação entre a ingestão crônica desses medicamentos pediátricos e a maior incidência de cárie dentária, relacionada à presença da sacarose na sua composição $41,53,145,146,154$. Porém, quanto à presença de flúor e uma possível associação com a fluorose, pesquisas têm se limitado ao estudo de algumas vitaminas contendo o mineral ${ }^{62,171}$. Nota-se na literatura médico-odontológica uma falta de informações sobre a presença de fluoretos em medicamentos, com relação à fluorose. 
A Secretaria de Higiene e Saúde de Santos ${ }^{62}$ (1996) apresentou uma lista ao Ministério da Saúde para que medicamentos que contenham flúor sejam controlados, com base em que nas regiões onde a água é tratada com flúor, existe de fato um risco, quando o pediatra receita um medicamento que, na sua composição, contém fluoreto de sódio. Na relação de medicamentos condenados pela Secretaria em regiões onde existe a fluoretação em massa estão citados Fluodel, Fluornatrium, Fluoreto de Sódio Primá, Novodentin, Calci-Ped, Calcitran B12, Deficical B-12, Fluornatrium-Vit, Hypercálcico, Kalyamon B-12, Kindcálcio suspensão, Nativit Flúor, Suspensão de Calciferol B-12 Composta, Poly-VI-Flúor, Selectcálcio, TRI-VI-Flúor, Fluorvit, Gevral Super, Natalins com flúor, Rarical com Vitaminas, Rarical com Vitaminas Infantil, Rariplex, Teragran M, Teragran M PréNatal, Vitagestam, Vitasay, Calciferol, Calcigenol B-12, Calcigenol Irradiado e Gestavit com Flúor.

VILLENA; CURY $^{171}$ (1999) consideraram 12 marcas comerciais de vitaminas como suplementos fluretados. As marcas comerciais relacionadas foram o Tri-Vi-Flúor solução, Poly-Vi-Flúor solução, Flúor Natrium comprimidos, Calciferol $\mathrm{B}_{12}$ suspensão, Glucal $B_{12}$ suspensão, Deficical $B_{12}$ suspensão, Selecta Cálcio suspensão, Calciped suspensão, Calcigenol Irradiado, Calcitran $\mathrm{B}_{12}$ suspensão, Kalyamon $\mathrm{B}_{12}$ suspensão, Rarical infantil suspensão. Destes, 10 ou 83,3\% eram recomendados para lactentes e/ou recém-nascidos, pelos fabricantes.

O Comitê de Nutrição da Sociedade Canadense de Pediatria, em 1987, já recomendou cautela para o uso rotineiro de vitaminas com flúor, desde que o potencial danoso de uma overdose de flúor aumenta com o seu uso ${ }^{69}$. 
Recentemente, CASTRO et al. ${ }^{25}$ (2000), ao realizar um levantamento com 51 crianças no Rio de Janeiro, constataram que $11,8 \%$ apresentavam sinais de fluorose, sendo que a história de ingestão de vitaminas contendo flúor (Calcigenol ${ }^{\circledR}$ Hoechst Marion Roussel; e Kalyamon ${ }^{\circledR}$ - Janssen-Cilag) teve relação significante entre os possíveis fatores de risco para a fluorose nesse estudo. 
3 PROPOSICÃO 


\section{PROPOSIÇÃO}

Com uma amostra de 114 medicamentos líquidos mais freqüentemente consumidos por crianças com problemas de saúde crônicos, em diversas especialidades médicas, o presente estudo se propôs a:

3.1 Analisar a presença ou a ausência de flúor nos referidos medicamentos, através da avaliação da concentração de flúor total $(\mathrm{FT})$;

3.2 Avaliar a concentração de flúor solúvel em $\mathrm{HCl}$ 0,01 M (FS) dos medicamentos que apresentarem FT superior à faixa de segurança estipulada para uma criança de $12 \mathrm{~kg} \mathrm{e}$;

3.3 Destacar os medicamentos que apresentassem FS superior à faixa de segurança estipulada para uma criança de $12 \mathrm{~kg}$, ou considerados como fatores de risco ao desenvolvimento da fluorose dentária. 
4 MATERIAL E MÉTODOS 


\section{MATERIAL E MÉTODOS}

\subsection{MATERIAL}

O material utilizado nos diferentes procedimentos realizados nesta pesquisa está discriminado a seguir:

\subsubsection{Medicamentos}

Todos os 114 medicamentos de uso pediátrico selecionados para a $1^{\mathrm{a}}$. fase desta pesquisa (Análise da concentração de FT) foram distribuídos em 13 grupos, sendo apresentados a seguir, nas tabelas de 4.1 a 4.13 , com seus respectivos princípios ativos, fabricantes, locais de fabricação e lotes.

Os grupos, elaborados com o objetivo de proporcionar melhor organização do material, foram classificados de acordo com a indicação clínica dos medicamentos. 
Métodos

TABELA 4.1 - Analgésicos antiinflamatórios antitérmicos

\begin{tabular}{|c|c|c|c|}
\hline Medicamento & Princípio Ativo & Fabricante & Lote \\
\hline \multirow[t]{2}{*}{ BARALGIN ${ }^{\circledR}$ M gotas } & Dipirona Sódica & Glaxo Wellcome & 0004522 \\
\hline & & Rio de Janeiro - RJ & \\
\hline \multirow[t]{2}{*}{ CATAFLAM $^{\circledR}$ gotas } & Diclofenaco & Novartis & Z63850 \\
\hline & Resinato & Taboão da Serra - SP & \\
\hline \multirow[t]{2}{*}{ CATAFLAM ${ }^{\circledR}$ suspensão oral } & Diclofenaco & Novartis & 60759 \\
\hline & Resinato & Taboão da Serra - SP & \\
\hline \multirow[t]{2}{*}{ FENBURIL gotas } & Diclofenaco & De Mayo & 2799002 \\
\hline & Resinato & Rio de Janeiro - RJ & \\
\hline \multirow{2}{*}{ FLOGONAC gotas } & Diclofenaco & Haller & 1599004 \\
\hline & Resinato & Rio de Janeiro - RJ & \\
\hline \multirow[t]{2}{*}{ INFLAMENE ${ }^{\circledR}$ suspensão oral } & Piroxicam & Farmalab-Chiesi & 005 \\
\hline & & Santana de Parnaíba - SP & \\
\hline \multirow[t]{2}{*}{ MAXILIV gotas } & Dipirona Sódica & Aché & 0001785 \\
\hline & & Guarulhos - SP & \\
\hline \multirow[t]{2}{*}{ NISULID ${ }^{\circledR}$ gotas } & Nimesulida & Asta Medica & 00570 \\
\hline & & São Paulo - SP & \\
\hline \multirow[t]{2}{*}{ NOVALGINA ${ }^{\circledR}$ gotas } & Dipirona Sódica & Hoechst Marion Roussel & 9909039 \\
\hline & & Suzano - SP & \\
\hline \multirow[t]{2}{*}{ NOVALGINA ${ }^{\circledR}$ solução oral } & Dipirona Sódica & Hoechst Marion Roussel & 9904564 \\
\hline & & Suzano - SP & \\
\hline TYLENOL ${ }^{\circledR}$ BEBÊ gotas em & Paracetamol & Cilag & CDM051 \\
\hline suspensão & & São José dos Campos - SP & \\
\hline TYLENOL ${ }^{\circledR}$ CRIANÇA líquido em & Paracetamol & Cilag & DPM150 \\
\hline suspensão & & São José dos Campos - SP & \\
\hline \multirow[t]{2}{*}{ TYLENOL ${ }^{\circledR}$ gotas } & Paracetamol & Cilag & 902064 \\
\hline & & São José dos Campos - SP & \\
\hline
\end{tabular}


Métodos

TABELA 4.2 - Antibióticos

\begin{tabular}{|c|c|c|c|}
\hline Medicamento & Princípio Ativo & Fabricante & Lote \\
\hline AMOXIFAR 250mg suspensão & Amoxicilina & $\begin{array}{c}\text { Farmoquímica } \\
\text { Rio de Janeiro - RJ }\end{array}$ & $139 / 99$ \\
\hline AMPLACILINA ${ }^{\circledR}$ suspensão oral & Ampicilina & $\begin{array}{c}\text { Eurofarma } \\
\text { São Paulo - SP }\end{array}$ & 000799 \\
\hline $\begin{array}{l}\text { CEFAMOX }{ }^{\circledR} 250 \mathrm{mg} / 5 \mathrm{~mL} \text { suspensão } \\
\text { oral }\end{array}$ & $\begin{array}{c}\text { Cefadroxil } \\
\text { Monoidratado }\end{array}$ & $\begin{array}{l}\text { Bristol-Myers-Squibb } \\
\text { São Paulo - SP }\end{array}$ & 132928 \\
\hline CLAVULIN ${ }^{\circledR}$ BD $400 \mathrm{mg}$ suspensão oral & $\begin{array}{c}\text { Amoxicilina } \\
\text { Clavulanato de } \\
\text { Potássio }\end{array}$ & $\begin{array}{l}\text { SmithKline Beecham } \\
\text { Rio de Janeiro - RJ }\end{array}$ & $90206 \mathrm{~A}$ \\
\hline ERITREX 250mg suspensão oral & $\begin{array}{l}\text { Estolato de } \\
\text { Eritromicina }\end{array}$ & $\begin{array}{l}\text { Aché } \\
\text { Guarulhos - SP }\end{array}$ & 0000677 \\
\hline KEFLEX ${ }^{\circledR} 250$ mg líquido & $\begin{array}{c}\text { Cefalexina } \\
\text { Monoidratada }\end{array}$ & $\begin{array}{c}\text { Lilly } \\
\text { São Paulo - SP }\end{array}$ & $346258 \mathrm{~K}$ \\
\hline $\begin{array}{l}\mathrm{KLARICID}^{\circledR} 125 \mathrm{mg} / 5 \mathrm{~mL} \text { suspensão } \\
\text { pediátrica }\end{array}$ & Claritromicina & $\begin{array}{c}\text { Abbott } \\
\text { São Paulo - SP }\end{array}$ & $55100 Q P$ \\
\hline $\begin{array}{l}\mathrm{KLARICID}^{\circledR} 250 \mathrm{mg} / 5 \mathrm{~mL} \text { suspensão } \\
\text { pediátrica }\end{array}$ & Claritromicina & $\begin{array}{c}\text { Abbott } \\
\text { São Paulo - SP }\end{array}$ & $54120 Q P$ \\
\hline NOVOCILIN 250mg suspensão oral & Amoxicilina & $\begin{array}{l}\text { Aché } \\
\text { Guarulhos - SP }\end{array}$ & L9903542 \\
\hline ORELOX suspensão oral & $\begin{array}{l}\text { Cefpodoxima } \\
\text { Proxetil }\end{array}$ & $\begin{array}{c}\text { Hoechst Marion Roussel } \\
\text { Suzano - SP }\end{array}$ & 578 \\
\hline PEN-VE-ORAL ${ }^{\circledR}$ solução oral & $\begin{array}{c}\text { Fenoximetilpenicilina } \\
\text { Potássica }\end{array}$ & $\begin{array}{c}\text { Eurofarma } \\
\text { São Paulo - SP }\end{array}$ & 000300 \\
\hline RESPICILIN ${ }^{\circledR} 250 \mathrm{mg}$ suspensão & Amoxicilina & $\begin{array}{c}\text { Haller } \\
\text { Rio de Janeiro - RJ }\end{array}$ & 5199006 \\
\hline SELIMAX $200 \mathrm{mg} / 5 \mathrm{~mL}$ suspensão & Azitromicina & $\begin{array}{l}\text { Libbs } \\
\text { São Paulo - SP }\end{array}$ & $90704 \mathrm{~A}$ \\
\hline VELAMOX ${ }^{\circledR} 250 \mathrm{mg} / 5 \mathrm{~mL}$ suspensão & Amoxicilina & $\begin{array}{c}\text { Novaquímica-Sigma } \\
\text { Hortolândia - SP }\end{array}$ & 994223 \\
\hline
\end{tabular}


Métodos

TABELA 4.3 - Sulfas

\begin{tabular}{|c|c|c|c|}
\hline Medicamento & Princípio Ativo & Fabricante & Lote \\
\hline \multirow[t]{2}{*}{ BACTRIM $^{\circledR}$ suspensão pediátrica } & Sulfametoxazol & Roche & 103926 \\
\hline & Trimetoprima & Rio de Janeiro - RJ & \\
\hline \multirow[t]{2}{*}{ DIENTRIN ${ }^{\circledR}$ suspensão oral } & Sulfametoxazol & Sanofi & 9112483 \\
\hline & Trimetoprima & Rio de Janeiro - RJ & \\
\hline \multirow[t]{2}{*}{ DUOCTRIM suspensão oral } & Sulfametoxazol & Haller & 1099004 \\
\hline & Trimetoprima & Rio de Janeiro - RJ & \\
\hline \multirow[t]{2}{*}{ ESPECTRIN ${ }^{\circledR}$ suspensão pediátrica } & Sulfametoxazol & Glaxo Wellcome & OC5790 \\
\hline & Trimetoprima & Rio de Janeiro - RJ & \\
\hline \multirow[t]{2}{*}{ SEPTIOLAN suspensão pediátrica } & Sulfametoxazol & Clímax & 98087 \\
\hline & Trimetoprima & São Paulo - SP & \\
\hline \multirow[t]{2}{*}{ TRIMEXAZOL ${ }^{\circledR}$ pediátrico suspensão } & Sulfametoxazol & Sanofi & 9044107 \\
\hline & Trimetoprima & Rio de Janeiro - RJ & \\
\hline
\end{tabular}

TABELA 4.4 - Medicamentos para nefropatias

\begin{tabular}{|c|c|c|c|}
\hline Medicamento & Princípio Ativo & Fabricante & Lote \\
\hline \multirow[t]{2}{*}{ HANTINA ${ }^{\circledR}$ suspensão oral } & Nitrofurantoína & Apsen & 005011 \\
\hline & & São Paulo - SP & \\
\hline \multirow[t]{2}{*}{ PIPUROL ${ }^{\circledR}$ xarope } & Ácido Pipemídico & Zambon & 52355 \\
\hline & & São Paulo - SP & \\
\hline \multirow[t]{2}{*}{ WINTOMYLON ${ }^{\circledR}$ suspensão } & Ácido Nalidíxico & Sanofi & 9101599 \\
\hline & & Rio de Janeiro - RJ & \\
\hline
\end{tabular}


Métodos

TABELA 4.5 - Corticosteróides

\begin{tabular}{|c|c|c|c|}
\hline Medicamento & Princípio Ativo & Fabricante & Lote \\
\hline CELESTAMINE* $^{*}$ xarope & $\begin{array}{c}\text { Maleato de } \\
\text { Dexclorfeniramina } \\
\text { Betametasona }\end{array}$ & $\begin{array}{c}\text { Schering-Plough } \\
\text { Rio de Janeiro - RJ }\end{array}$ & 012 \\
\hline CELESTONE* $^{*}$ elixir & Betametasona & $\begin{array}{l}\text { Schering-Plough } \\
\text { Rio de Janeiro - RJ }\end{array}$ & 908 \\
\hline CELESTONE $^{*}$ gotas & Betametasona & $\begin{array}{l}\text { Schering-Plough } \\
\text { Rio de Janeiro - RJ }\end{array}$ & 002 \\
\hline DECADRON* $0,5 \mathrm{mg} / 5 \mathrm{~mL}$ elixir & Dexametasona & $\begin{array}{c}\text { Prodrome } \\
\text { Campinas - SP }\end{array}$ & 98071301 \\
\hline PREDSIM* $15 \mathrm{mg} / 5 \mathrm{~mL}$ solução oral & $\begin{array}{c}\text { Fosfato Sódico de } \\
\text { Prednisolona }\end{array}$ & $\begin{array}{l}\text { Schering-Plough } \\
\text { Rio de Janeiro - RJ }\end{array}$ & 004 \\
\hline PRELONE ${ }^{\circledR} 3 \mathrm{mg} / \mathrm{mL}$ solução oral & Prednisolona & $\begin{array}{l}\text { Asta Medica } \\
\text { São Paulo - SP }\end{array}$ & 00591 \\
\hline $\begin{array}{l}\text { RHODIA FARMA - PREDNISOLONA } \\
\text { solução oral }\end{array}$ & $\begin{array}{l}\text { Fosfato Sódico de } \\
\text { Prednisolona }\end{array}$ & $\begin{array}{l}\text { Rhodia Farma } \\
\text { São Paulo - SP }\end{array}$ & 2898 \\
\hline
\end{tabular}


TABELA 4.6 - Anti-histamínicos

\begin{tabular}{|c|c|c|c|}
\hline Medicamento & Princípio Ativo & Fabricante & Lote \\
\hline \multirow[t]{2}{*}{ CETRIZIN $10 \mathrm{mg} / \mathrm{mL}$ gotas } & Dicloridrato de & Sintofarma & 4183 \\
\hline & Cetirizina & Taboão da Serra - SP & \\
\hline \multirow[t]{2}{*}{ CLARITIN* pediátrico $5 \mathrm{mg} / 5 \mathrm{~mL}$} & Loratadina & Schering-Plough & 930 \\
\hline & & Rio de Janeiro - RJ & \\
\hline \multirow[t]{2}{*}{ LORALERG xarope } & Loratadina & Farmasa & 115 \\
\hline & & São Paulo - SP & \\
\hline \multirow[t]{2}{*}{ LOREMIX xarope } & Loratadina & Ativus & EH 61 \\
\hline & & Valinhos - SP & \\
\hline \multirow{5}{*}{ POLARAMINE* expectorante } & Maleato de & Schering-Plough & 012 \\
\hline & Dexclorfeniramina & Rio de Janeiro - RJ & \\
\hline & Sulfato de & & \\
\hline & Pseudoefedrina & & \\
\hline & Guaifenesina & & \\
\hline \multirow[t]{2}{*}{ POLARAMINE* líquido 2mg/5mL } & Maleato de & Schering-Plough & 103 \\
\hline & Dexclorfeniramina & Rio de Janeiro - RJ & \\
\hline \multirow[t]{3}{*}{ ZETALERG solução oral } & Dicloridrato de & Uci-Farma & 90728 \\
\hline & Cetirizina & São Bernardo do & \\
\hline & & Campo - SP & \\
\hline \multirow[t]{2}{*}{ ZYRTEC ${ }^{\circledR}$ solução oral } & Dicloridrato de & Glaxo Wellcome & $8 \mathrm{H} 2390$ \\
\hline & Cetirizina & Rio de Janeiro - RJ & \\
\hline
\end{tabular}


TABELA 4.7 - Broncodilatadores

\begin{tabular}{lccc}
\hline \multicolumn{1}{c}{ Medicamento } & Princípio Ativo & Fabricante & Lote \\
\hline AEROFLUX edulito & Sulfato de & Glaxo Wellcome & 1A6640E \\
& Salbutamol & Rio de Janeiro - RJ & \\
& Guaifenesina & & \\
& Citrato de Sódio & & \\
AEROLIN ${ }^{\circledR}$ xarope & Sulfato de & Glaxo Wellcome & 9B3155 \\
& Salbutamol & Rio de Janeiro - RJ & \\
ASMAX gotas & Cetotifeno & Ativus & EM29 \\
ASMEN ${ }^{\circledR} 0,2 \mathrm{mg} / \mathrm{mL}$ xarope & Cetotifeno & Falinhos - SP & \\
BEROTEC ${ }^{\circledR}$ xarope pediátrico & Fumarato & Santana de Parnaíba - SP & \\
& Bromidrato de & Boehringer De Angeli & \multirow{2}{*}{3035} \\
BRICANYL ${ }^{\circledR}$ xarope & Fenoterol & Itapecerica da Serra - SP & \\
& Sulfato de & Astra & A01752 \\
BRONDILAT xarope pediátrico & Terbutalina & Cotia - SP & \\
& Acebrofilina & Aché & 98176 \\
& & Guarulhos - SP & \\
\hline \hline
\end{tabular}


Métodos

TABELA 4.8 - Mucolíticos

\begin{tabular}{|c|c|c|c|}
\hline Medicamento & Princípio Ativo & Fabricante & Lote \\
\hline BRONCOFLUX pediátrico & Ambroxol & $\begin{array}{c}\text { Farmasa } \\
\text { São Paulo - SP }\end{array}$ & 111 \\
\hline DECONGEX PLUS gotas & Cloridrato de & Aché & 0002055 \\
\hline & Fenilpropanolamina & Guarulhos - SP & \\
\hline & Cloridrato de & & \\
\hline & Fenilefrina & & \\
\hline & Maleato de & & \\
\hline & Bronfeniramina & & \\
\hline FLUIBRON $^{\circledR} 7,5 \mathrm{mg} / \mathrm{mL}$ gotas & Ambroxol Cloridrato & $\begin{array}{c}\text { Farmalab-Chiesi } \\
\text { Santana de Parnaíba - SP }\end{array}$ & 066 \\
\hline FLUIBRON ${ }^{\circledR}$ xarope pediátrico & Ambroxol Cloridrato & $\begin{array}{c}\text { Farmalab-Chiesi } \\
\text { Santana de Parnaíba - SP }\end{array}$ & 037 \\
\hline MUCIBRON ${ }^{\circledR}$ xarope pediátrico & Ambroxol & $\begin{array}{c}\text { Medley } \\
\text { Campinas - SP }\end{array}$ & 9905066 \\
\hline MUCOFLUX 100 xarope pediátrico & Carbocisteína & $\begin{array}{c}\text { Merck } \\
\text { Rio de Janeiro - RJ }\end{array}$ & 2193272 \\
\hline MUCOLITIC ${ }^{\circledR}$ xarope pediátrico & Carbocisteína & $\begin{array}{c}\text { BYK } \\
\text { Diadema - SP }\end{array}$ & 005192 \\
\hline MUCOSOLVAN ${ }^{\circledR}$ xarope & $\begin{array}{l}\text { Cloridrato de } \\
\text { Ambroxol }\end{array}$ & $\begin{array}{c}\text { De Angeli } \\
\text { Itapecerica da Serra - SP }\end{array}$ & 7780 \\
\hline MUCOTOSS ${ }^{\circledR}$ infantil & Carbocisteína & $\begin{array}{c}\text { Novaquímica-Sigma } \\
\text { Hortolândia - SP }\end{array}$ & 002696 \\
\hline
\end{tabular}


TABELA 4.9 - Antitussígenos

\begin{tabular}{lccc}
\hline \hline \multicolumn{1}{c}{ Medicamento } & Princípio Ativo & Fabricante & Lote \\
\hline SEKI ${ }^{\circledR}$ xarope & Fendizoato de & Zambon & 52137 \\
& Cloperastina & São Paulo - SP & \\
VIBRAL xarope & Dropropizina & Sintofarma & 3104 \\
& & Taboão da Serra - SP & \\
ZYPLO* 6mg/mL xarope & Levodropropizina & Pfizer & $904-98007$ \\
& & Guarulhos - SP & \\
& & & \\
\hline \hline
\end{tabular}

TABELA 4.10 - Anticonvulsivantes

\begin{tabular}{|c|c|c|c|}
\hline Medicamento & Princípio Ativo & Fabricante & Lote \\
\hline DEPAKENE $^{\circledR} 250 \mathrm{mg} / 5 \mathrm{~mL}$ xarope & $\begin{array}{c}\text { Ácido Valpróico } \\
\text { Valproato de } \\
\text { Sódio }\end{array}$ & $\begin{array}{c}\text { Abbott } \\
\text { São Paulo - SP }\end{array}$ & 71189QP \\
\hline EPELIN® suspensão oral & $\begin{array}{c}\text { Fenitoína } \\
\text { Fenitoína Sódica }\end{array}$ & $\begin{array}{l}\text { Parke-Davis } \\
\text { Guarulhos - SP }\end{array}$ & 0002647 \\
\hline GARDENAL pediátrico gotas $4 \%$ & Fenobarbital & $\begin{array}{l}\text { Rhodia Farma } \\
\text { São Paulo - SP }\end{array}$ & 7656 \\
\hline TEGRETOL ${ }^{\circledR}$ suspensão oral a 2\% & Carbamazepina & $\begin{array}{c}\text { Novartis } \\
\text { Taboão da Serra - SP }\end{array}$ & $\mathrm{Z70620}$ \\
\hline
\end{tabular}


Métodos

TABELA 4.11 - Medicamentos para cardiopatias

\begin{tabular}{lccc}
\hline \hline \multicolumn{1}{c}{ Medicamento } & Princípio Ativo & Fabricante & Lote \\
\hline ANCORON gotas & Cloridrato de & Libbs & 0.0606 \\
& Amiodarona & São Paulo - SP & \\
CLORETO DE POTÁSSIO ARISTON & Cloreto de & Ariston & 1704 \\
6\% xarope & Potássio & São Paulo - SP & \\
DIGOXINA 0,05mg elixir pediátrico & Digoxina & Glaxo Wellcome & A03221 \\
& & Rio de Janeiro - RJ & \\
DIGOXINA solução oral & Digoxina & Glaxo Wellcome & A03394 \\
& & Rio de Janeiro - RJ & \\
\hline \hline
\end{tabular}


Métodos

TABELA 4.12 - Medicamentos para gastroenteropatias

\begin{tabular}{|c|c|c|c|}
\hline Medicamento & Princípio Ativo & Fabricante & Lote \\
\hline AGAROL emulsão oral & $\begin{array}{l}\text { Óleo Mineral } \\
\text { Ágar-Ágar } \\
\text { Fenolftaleína }\end{array}$ & $\begin{array}{c}\text { Aché } \\
\text { Guarulhos - SP }\end{array}$ & 2731 \\
\hline ANTAK ${ }^{\circledR} 150 \mathrm{mg} / 10 \mathrm{~mL}$ xarope & $\begin{array}{l}\text { Cloridrato de } \\
\text { Ranitidina }\end{array}$ & $\begin{array}{c}\text { Glaxo Wellcome } \\
\text { Rio de Janeiro - RJ }\end{array}$ & $\mathrm{OH} 6241$ \\
\hline DRAMIN ${ }^{\circledR}$ B6 gotas pediátrico & $\begin{array}{l}\text { Dimenidrinato } \\
\text { Cloridrato de } \\
\text { Piridoxina }\end{array}$ & $\begin{array}{c}\text { BYK } \\
\text { Diadema - SP }\end{array}$ & $\begin{array}{c}00604906 \\
00\end{array}$ \\
\hline DIGEREX gotas pediátricas & Bromoprida & $\begin{array}{c}\text { De Mayo } \\
\text { Rio de Janeiro - RJ }\end{array}$ & 1999002 \\
\hline ESPASMO LUFTAL ${ }^{\circledR}$ gotas & $\begin{array}{c}\text { Dimeticona } \\
\text { Metilbrometo de } \\
\text { Homatropina }\end{array}$ & $\begin{array}{l}\text { Bristol-Myers-Squibb } \\
\text { São Paulo - SP }\end{array}$ & 135175 \\
\hline KAOMAGMA ${ }^{\circledR}$ suspensão oral & $\begin{array}{l}\text { Caolim Coloidal } \\
\text { Pectina Cítrica } \\
\text { Hidróxido de } \\
\text { Alumínio }\end{array}$ & $\begin{array}{c}\text { Novaquímica-Sigma } \\
\text { Hortolândia - SP }\end{array}$ & 000698 \\
\hline LABEL ${ }^{\circledR}$ líquido & $\begin{array}{l}\text { Cloridrato de } \\
\text { Ranitidina }\end{array}$ & $\begin{array}{c}\text { Asta Medica } \\
\text { São Paulo - SP }\end{array}$ & 01290 \\
\hline MOTILIUM ${ }^{\circledR}$ suspensão & Domperidona & $\begin{array}{c}\text { Janssen-Cilag } \\
\text { São José dos Campos - SP }\end{array}$ & 003893 \\
\hline PANGEST $^{\circledR}$ gotas pediátricas & Bromoprida & $\begin{array}{c}\text { Farmasa } \\
\text { São Paulo - SP }\end{array}$ & 0016 \\
\hline PLAMET solução oral & Bromoprida & $\begin{array}{c}\text { Libbs } \\
\text { São Paulo - SP }\end{array}$ & 00877 \\
\hline
\end{tabular}


Métodos

TABELA 4.13 - Polivitamínicos

\begin{tabular}{|c|c|c|c|}
\hline Medicamento & Princípio Ativo & Fabricante & Lote \\
\hline \multirow[t]{2}{*}{ ADEROGIL D3 gotas } & Colecalciferol & Sarsa & 9800886 \\
\hline & Acetato de Retinol & São Paulo - SP & \\
\hline \multirow[t]{2}{*}{ AD-TIL solução oral } & Vitaminas A e D & BYK & 207058 \\
\hline & & Diadema - SP & \\
\hline \multirow[t]{3}{*}{ BETOZONE solução oral } & Sulfato Ferroso & De Mayo & 98175 \\
\hline & Complexo B & Rio de Janeiro - RJ & \\
\hline & Associações & & \\
\hline CALCIGENOL ${ }^{\circledR}$ COMPOSTO B12 & Fosfato Tricálcio & Hoechst Marion Roussel & 0007412 \\
\hline suspensão & $\begin{array}{l}\text { Vitaminas B12 e } \\
\text { D2 } \\
\text { Fluoreto de Sódio }\end{array}$ & Suzano - SP & \\
\hline CALCIGENOL ${ }^{\circledR}$ IRRADIADO & Fosfato Tricálcio & Hoechst Marion Roussel & 0008001 \\
\hline \multirow[t]{2}{*}{ suspensão } & Vitamina D2 & Suzano - SP & \\
\hline & Fluoreto de Sódio & & \\
\hline \multirow[t]{2}{*}{ CEBION ${ }^{\circledR}$ gotas } & Ácido Ascórbico & Merck & 2013302 \\
\hline & & Rio de Janeiro - RJ & \\
\hline \multirow[t]{2}{*}{ CENALFAN gotas } & Polivitamina A, C & Novaquímica-Sigma & 993454 \\
\hline & e E & Hortolândia - SP & \\
\hline \multirow[t]{2}{*}{ CEWIN ${ }^{\circledR} 200 \mathrm{mg} / \mathrm{mL}$ gotas } & Ácido Ascórbico & Sanofi & 9072733 \\
\hline & & Rio de Janeiro - RJ & \\
\hline \multirow[t]{2}{*}{ COBACTIN ${ }^{\circledR}$ xarope } & Cloridrato de & Zambon & 51431 \\
\hline & $\begin{array}{c}\text { Ciproeptadina } \\
\text { Cobamida }\end{array}$ & São Paulo - SP & \\
\hline \multirow[t]{3}{*}{ COBAVITAL xarope } & Cloridrato de & Sintofarma & 1555 \\
\hline & Ciproeptadina & Taboão da Serra - SP & \\
\hline & Cobamida & & \\
\hline \multirow[t]{2}{*}{ COMBIRON gotas } & Sulfato Ferroso e & Aché & 0001115 \\
\hline & Associações & Guarulhos - SP & \\
\hline \multirow[t]{2}{*}{ COMBIRON solução oral } & Sulfato Ferroso e & Aché & 9902458 \\
\hline & Associações & Guarulhos - SP & \\
\hline
\end{tabular}


Continuação da TABELA 4.13 - Polivitamínicos

KALYAMON ${ }^{\circledR}$ B-12 suspensão

KIDDI PHARMATON ${ }^{\circledR}$ xarope

LEUCOGEN xarope

NEUTROFER ${ }^{\circledR} 250 \mathrm{mg} / \mathrm{mL}$ gotas

NEUTROFER ${ }^{\circledR}$ fólico

NONAVIT solução oral

NORIPURUM ${ }^{\circledR}$ xarope

NOVOFER gotas

NUTRI-PED ${ }^{\circledR}$ suspensão

PROFOL suspensão oral

REDOXON ${ }^{\circledR} 200 \mathrm{mg}$ gotas

REVITAM $^{\circledR}$ JÚNIOR solução oral

SULFATO FERROSO gotas

VITA-PED ${ }^{\circledR}$ gotas
Polivitamínico

Poliminerais

Polivitamínico Cálcio Fósforo Lisina

Timomodulina

Ferro Quelato

Glicinato

Ferro Quelato Glicinato Ácido Fólico Suplemento Vitamínico Mineral Hidróxido de Ferro III Polimaltosado Sulfato Ferroso e Associações

Polivitaminas

Cloridrato de

$$
\text { Buclizina }
$$

Ácido Ascórbico

Polivitaminas

Sulfato Ferroso

Polivitaminas

$$
\text { Janssen-Cilag }
$$

São José dos Campos - SP

Boehringer Ingelheim

8934

Itapecerica da Serra - SP

Aché

9902721

Guarulhos - SP

Novaquímica-Sigma

024315

Hortolândia - SP

Novaquímica-Sigma

018952

Hortolândia - SP

De Mayo

3199007

Rio de Janeiro - RJ

BYK

308049

Diadema - SP

Aché

0002365

Guarulhos - SP

Bébia

9K029A

Guarulhos - SP

Medley

0006249

Campinas - SP

Roche

107331

Rio de Janeiro - RJ

Biolab

202408

Taboão da Serra - SP

Neoquímica

3458

Anápolis - GO

Bébia

OD033A/1

Guarulhos - SP 


\subsubsection{Material utilizado para a análise da concentração de FT}

$\unlhd$ Agitador de tubos, modelo 251 (Fanem $^{\circledR}$, São Paulo, SP, Brasil)

$\unlhd$ Toalha de papel absorvente $\left(\right.$ Chifon $^{\circledR}$ Scott, Klabin Kimberly S.A., Mogi das Cruzes, SP, Brasil)

ऽ Pipeta automática modelo P100 (Gilson ${ }^{\circledR}$, Villiers-le-Bel, França)

ऽ Pipeta automática modelo P1000 (Gilson ${ }^{\circledR}$, Villiers-le-Bel, França)

$\searrow$ Pipeta automática modelo P5000 (Gilson ${ }^{\circledR}$, Villiers-le-Bel, França)

$₫$ Ponteiras para pipeta modelo P100 (Gilson ${ }^{\circledR}$, Villiers-le-Bel, França)

$\unlhd$ Ponteiras para pipeta modelo P1000 (Gilson ${ }^{\circledR}$, Villiers-le-Bel, França)

$\unlhd$ Ponteiras para pipeta modelo P5000 (Gilson ${ }^{\circledR}$, Villiers-le-Bel, França)

$\searrow$ Placas de Petri de poliestireno estéril - $60 \times 15 \mathrm{~mm}$, Falcon $\mathrm{n}^{\circ} .1007$ (Becton Dickson Labware, Franklin Lakes, New Jersey, EUA)

$\unlhd$ Tampas de polietileno - Falcon n. 2030 (Becton Dickson Labware, Franklin Lakes, New Jersey, EUA)

$\searrow$ Tubos de ensaio de poliestireno - $17 \times 100 \mathrm{~mm}$ - Falcon $\mathrm{n}^{\circ} .2017$ (Becton Dickson Labware, Franklin Lakes, New Jersey, EUA)

$\unlhd$ Caneta marcador permanente CD para plásticos, acrílicos, vinil e vidros (Pilot Pen do Brasil S.A., São Paulo, SP, Brasil)

$\unlhd$ Soldador - modelo 113540410 (Craftsman Soldering Iron, Taiwan)

\ Vaselina sólida branca (Indústria Farmacéutica Rioquímica Ltda., São José do Rio Preto, SP, Brasil)

ฯ Bisnaga de "catchup" - Referência 150/3 (Plastigel, Brasil)

$\unlhd$ Parafilme (American National Can ${ }^{\mathrm{TM}}$, Menesha, WI, EUA) 
$\unlhd$ Béqueres de vidro de $50 \mathrm{~mL}$ e $150 \mathrm{~mL} \mathrm{n}^{\text {os }} .1000$ e 1005, respectivamente $\left(\right.$ Pyrex $^{\circledR}$, EUA)

$\unlhd$ Béqueres de vidro de $250 \mathrm{~mL}$ (Vidrolabor 101B ISO 3819, Brasil)

ฯ Água deionizada (Deionizador Barrilete 100L Permution - E. J. Krieger \& Cia. Ltda., Curitiba, PR, Brasil)

$\unlhd \mathrm{NaOH}$ 1,65 M (a partir de Hidróxido de Sódio em lentilhas puríssimo para análise, lote 501024, Merck S.A. Indústrias Químicas, Rio de Janeiro, RJ, Brasil)

ฐ HMDS em HCl 6,0 M (HMDS-HCl: a partir de HMDS, código H 4875, Sigma e Ácido Clorídrico 37\% P.A., lote K27124617-945, Merck, Darmstadt, Alemanha)

$\unlhd$ Ácido acético 0,66 M (a partir de Ácido Acético Glacial 100\%, lote 1216067001, Merck S.A. Indústrias Químicas, Rio de Janeiro, RJ, Brasil)

ฯ Padrão de NaF Ionplus 100 ppm F-(n. 940907, Orion Research Inc., Beverly, MA, EUA)

$\unlhd$ Fita crepe (3M do Brasil Ltda., Sumaré, SP, Brasil)

$\unlhd$ Mesa agitadora orbital plana modelo NT 145 (Nova Técnica, São Paulo, SP, Brasil)

$\unlhd$ Palito de sorvete com extremo achatado / quadrado (Theoto S.A. Indústria e Comércio, Jundiaí, SP, Brasil)

$\unlhd$ Compressas de gaze (Johnson \& Johnson*, São José dos Campos, SP, Brasil)

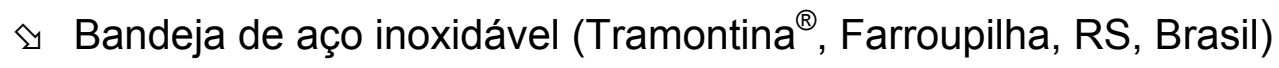


$\unlhd$ Estufa de cultura 502 - Orion (Fanem ${ }^{\circledR}$, São Paulo, SP, Brasil)

$\unlhd$ Estabilizador de corrente elétrica No Break (SMS) - Manager One, Line Interactive, microprocessado (SMS Tecnologia Eletrônica Ltda., Indústria Brasileira)

$\unlhd$ Analisador de íons Procyon, modelo SA 720 (Procyon Instrumentos Científica, São Paulo, SP, Brasil)

$\unlhd$ Eletrodo específico para íon flúor Orion, modelo 9609 (Orion Research, Cambridge, Mass, EUA)

$\unlhd$ Solução interna do eletrodo (Single Junction, Reference Electrode, Orion Filling Solution, 900001 Orion - Orion Research, Inc. - Beverly, MA, EUA)

ฐ Cronômetro Cronus, modelo TEC 965 (Technos, Zona Franca de Manaus, AM, Brasil)

$\unlhd$ Programa Excel - Microsoft ${ }^{\circledR}$

\subsubsection{Material utilizado para a análise da concentração de flúor solúvel em $\mathrm{HCl}$ 0,01 M (FS)}

$\unlhd$ Caneta marcador permanente CD para plásticos, acrílicos, vinil e vidros (Pilot Pen do Brasil S.A., São Paulo, SP, Brasil)

$\unlhd$ Tubos para centrífuga $n^{\circ} .03944$, lote A1 (Sorvall ${ }^{\circledR}$ Instruments, Du Pont, Newtown, Connecticut, EUA) 
ฯ Tampas de tubos para centrífuga $n^{\circ} .03268$ (Du Pont Company, Willmington, DE, EUA)

$\S$ Medicamentos (Tabela 4.14)

TABELA 4.14 - Medicamentos selecionados para a análise de FS

\begin{tabular}{lccc}
\hline \hline \multicolumn{1}{c}{ Medicamento } & Princípio Ativo & Fabricante & Lote \\
\hline CALCIGENOL $^{\circledR}$ & Fosfato Tricálcio & Sarsa & 0007412 \\
$\begin{array}{l}\text { COMPOSTO B12 } \\
\text { suspensão }\end{array}$ & Vitaminas B12 eD2 & Suzano - SP & \\
& Fluoreto de Sódio & & \\
CALCIGENOL $^{\circledR}$ & Fosfato Tricálcio & Sarsa & 0008001 \\
IRRADIADO suspensão & Vitamina D2 & Suzano - SP & \\
& Fluoreto de Sódio & & \\
EPELIN ${ }^{\circledR}$ suspensão & Fenitoína & Parke-Davis & 0002647 \\
oral & Fenitoína Sódica & Guarulhos - SP & \\
KALYAMON® B-12 & Polivitamínico & Janssen-Cilag & 013295 \\
suspensão & Poliminerais & São José dos Campos - & \\
& & SP & \\
\hline \hline
\end{tabular}

ฯ Agitador de tubos, modelo 251 (Fanem ${ }^{\circledR}$, São Paulo, SP, Brasil)

$\unlhd$ Toalha de papel absorvente (Chifon ${ }^{\circledR}$ Scott, Klabin Kimberly S.A., Mogi das Cruzes, SP, Brasil)

ฐ Pipeta automática modelo P100 (Gilson ${ }^{\circledR}$, Villiers-le-Bel, França)

ฯ Pipeta automática modelo P200 (Gilson ${ }^{\circledR}$, Villiers-le-Bel, França)

ฯ Pipeta automática modelo P1000 (Gilson ${ }^{\circledR}$, Villiers-le-Bel, França) 
ऽ Pipeta automática modelo P5000 (Gilson ${ }^{\circledR}$, Villiers-le-Bel, França)

ऽ Ponteiras para pipeta modelo P100 (Gilson ${ }^{\circledR}$, Villiers-le-Bel, França)

$\unlhd$ Ponteiras para pipeta modelo P200 (Gilson ${ }^{\circledR}$, Villiers-le-Bel, França)

$\unlhd$ Ponteiras para pipeta modelo P1000 (Gilson ${ }^{\circledR}$, Villiers-le-Bel, França)

$\unlhd$ Ponteiras para pipeta modelo P5000 (Gilson ${ }^{\circledR}$, Villiers-le-Bel, França)

$\unlhd$ Béqueres de vidro de $50 \mathrm{~mL}$ e $150 \mathrm{~mL} \mathrm{n}^{\text {os }} .1000$ e 1005, respectivamente $\left(\right.$ Pyrex $^{\circledR}$, EUA)

\ Béquer de polietileno de 2,0 L (Kartell, Itália)

ฐ $\mathrm{HCl}$ 0,01 M (a partir de Ácido Clorídrico 37\% P.A., lote K27124617945, Merck, Darmstadt, Alemanha)

$\unlhd \mathrm{HCl}$ 0,02 M (a partir de Ácido Clorídrico 37\% P.A., lote K27124617945, Merck, Darmstadt, Alemanha)

$\unlhd \mathrm{NaOH}$ 0,1 M (a partir de Hidróxido de Sódio em lentilhas puríssimo para análise, lote 501024, Merck S.A. Indústrias Químicas, Rio de Janeiro, RJ, Brasil)

§ TISAB III concentrado com CDTA (Orion, Orion Research, Inc., Beverly, MA, EUA)

ฯ Padrão de NaF lonplus 100 ppm F F $^{-} \mathrm{n}^{\circ}$. 940907, Orion Research Inc., Beverly, MA, EUA)

$\unlhd$ Fita crepe (3M do Brasil Ltda., Sumaré, SP, Brasil)

$\unlhd$ Banho-maria Evlab, modelo 015 (Evlab Indústria e Comércio de Produtos para Laboratórios Ltda., Londrina, PR, Brasil)

$\unlhd$ Mesa agitadora orbital plana modelo NT 145 (Nova Técnica, São Paulo, SP, Brasil) 
ฯ Centrífuga Sorvall Super Speed RC2-B Automatic Refrigerated (Sorvall $^{\circledR}$ Instruments, Ivan Sorvall Inc., Newtown, Connecticut, EUA)

ऽ Balança modelo 2009 (Record, São Paulo, SP, Brasil)

$\searrow$ Proveta de poliestireno de $10 \mathrm{~mL}\left(\mathrm{n}^{\circ} .3663-0010\right.$, Nalgene, EUA)

$\unlhd$ Béqueres de poliestireno de $10 \mathrm{~mL}\left(\mathrm{n}^{\circ} .50\right.$, Injeplast, SP, Brasil)

¿ Estabilizador de corrente elétrica No Break (SMS) - Manager One, Line Interactive, microprocessado (SMS Tecnologia Eletrônica Ltda., Indústria Brasileira)

$\searrow$ Analisador de íons Procyon, modelo SA 720 (Procyon Instrumentos Científica, São Paulo, SP, Brasil)

$\unlhd$ Eletrodo específico para íon flúor Orion, modelo 9609 (Orion Research, Cambridge, Mass, EUA)

$\searrow$ Solução interna do eletrodo (Single Junction, Reference Electrode, Orion Filling Solution, 900001 Orion - Orion Research, Inc. - Beverly, MA, EUA)

\ Cronômetro Cronus, modelo TEC 965 (Technos, Zona Franca de Manaus, AM, Brasil)

$\unlhd$ Programa Excel - Microsoft $^{\circledR}$ 


\subsection{MÉTODOS}

Todos os procedimentos realizados nesta pesquisa estão discriminados nos itens abaixo, seguindo sua ordem de execução.

\subsubsection{Seleção dos medicamentos}

A seleção dos medicamentos foi realizada após entrevistas com diversos médicos $(n=30)$ das áreas de Pediatria, Alergia, Cardiologia, Gastroenterologia, Hematologia, Hepatologia, Infectologia, Nefrologia, Neurologia, Pneumologia e Otorrinolaringologia. Estas áreas foram escolhidas uma vez que concentram a maioria dos casos de problemas de saúde crônicos pediátricos, inclusive com tratamento e manutenção medicamentosos com freqüência e por longo período de tempo.

A entrevista (Anexo 1) continha duas perguntas que abordavam quais eram os principais problemas de saúde crônicos pediátricos dentro de sua especialidade e quais eram os medicamentos mais utilizados nos protocolos terapêuticos (nome genérico e/ou nome comercial), com a finalidade de conhecer os medicamentos mais comumente prescritos às crianças nesses casos. 


\subsubsection{Obtenção dos medicamentos}

Uma amostra total de 114 medicamentos foi então obtida nas cidades de Bauru e Presidente Prudente - SP, Brasil, através de doações de amostras grátis e da compra diretamente da farmácia. As doações foram efetuadas gentilmente pelos próprios médicos, pela farmácia de uma associação assistencial (Associação Assistencial Adolpho Bezerra de Menezes), que serve a população carente de Presidente Prudente e, pela Unidade Básica de Atendimento ao SISUSP (UBAS) do Campus Administrativo de Bauru - Universidade de São Paulo. Alguns medicamentos, que são clássicos no protocolo terapêutico de algumas patologias crônicas importantes, não puderam ser obtidos por meio de doações, sendo então comprados diretamente na Farmácia Universitária, de Bauru. Todos os medicamentos, apresentados na forma líquida e de uso pediátrico, foram divididos em 13 grupos de acordo com a sua indicação clínica, já relacionados anteriormente (Tabelas 4.1 a 4.13).

\subsubsection{Homogeneização das amostras}

Até a execução dos testes bioquímicos, os medicamentos foram mantidos lacrados e conservados à temperatura ambiente, em local limpo, seco, arejado e protegido de iluminação.

Uma vez que comumente ocorre a precipitação de alguns componentes da fórmula durante o repouso, previamente à realização dos procedimentos para as 
dosagens de FT e de FS, cada frasco de medicamento foi agitado vigorosamente em um agitador de tubos (modelo 251 - Fanem ${ }^{\circledR}$ ), à velocidade 8 , de modo a homogeneizar o líquido. Esta agitação provoca a formação de bolhas, que são indesejáveis durante a pipetagem, devido à possibilidade de alteração de volume do líquido, com a inclusão de bolhas. Então, com os propósitos de reduzir o número de bolhas e preservar a homogeneidade do medicamento, em seguida, procedeu-se uma agitação manual suave, através de movimentos circulares, para a partir deste ponto realizar a captação e/ou pipetagem do volume de medicamento necessário para ambas as dosagens. Estas foram realizadas no Laboratório de Bioquímica, do Departamento de Ciências Biológicas da Faculdade de Odontologia de Bauru Universidade de São Paulo.

\subsubsection{Determinação da concentração de Flúor Total (FT)}

Para analisar a presença ou a ausência de flúor nos medicamentos, através da avaliação da concentração de flúor total (FT), empregou-se o método da difusão facilitada por HMDS em HCl 6,0 M (HMDS-HCl), proposta por TAVES ${ }^{163}$, em 1968, para extração do flúor.

Para tanto, utilizou-se para cada medicamento uma placa de Petri de poliestireno estéril (Falcon $n^{\circ}$. 1007), que foi a placa de difusão. No preparo desta placa, foi feito na tampa, próximo à borda, um orifício de 2,0 mm de diâmetro com soldador elétrico. No centro da placa, foi fixada com vaselina sólida uma tampa de 
polietileno (Falcon $n^{\circ}$. 2030), cortada em altura de modo que ficasse um pouco menor que a altura da placa de Petri fechada (Figura 4.1a).

Posteriormente, 1,0 mL de cada medicamento foi colocado juntamente com 2,0 $\mathrm{mL}$ de água deionizada na base da placa, externamente à tampa de polietileno. No centro desta tampa de polietileno foi colocado $0,1 \mathrm{~mL}$ de $\mathrm{NaOH}$ 1,65 M (Figura 4.1b).

Previamente à adição do $\mathrm{HMDS}-\mathrm{HCl}$, foi preciso fechar e vedar a placa de Petri, com a colocação de um cordão de vaselina sólida feito com o auxílio de uma bisnaga de "catchup", sem bolhas, em torno de todo o ângulo interno de sua tampa, pois sendo o HMDS altamente volátil, não poderia haver difusão de gases para o meio externo (Figura 4.1c).

Através do orifício feito na tampa de cada placa, foi colocado $1,0 \mathrm{~mL}$ de HMDS-HCl (Figura 4.1d), sendo o orifício imediatamente vedado com vaselina e parafilme (Figura 4.1e). Todos os cuidados de vedamento do conjunto com o meio externo são necessários, lembrando mais uma vez que o $\mathrm{HMDS}-\mathrm{HCl}$ é altamente volátil.

Em seguida, as placas foram empilhadas cuidadosamente, envoltas em faixas de papel toalha (que facilitam seguramente a remoção posterior de dentro dos béqueres), colocadas em béqueres de vidro de $250 \mathrm{~mL}$ e levadas à mesa agitadora orbital plana (Nova Técnica, modelo NT 145) em velocidade 2-3 por 12 horas (Figura 4.1f). 

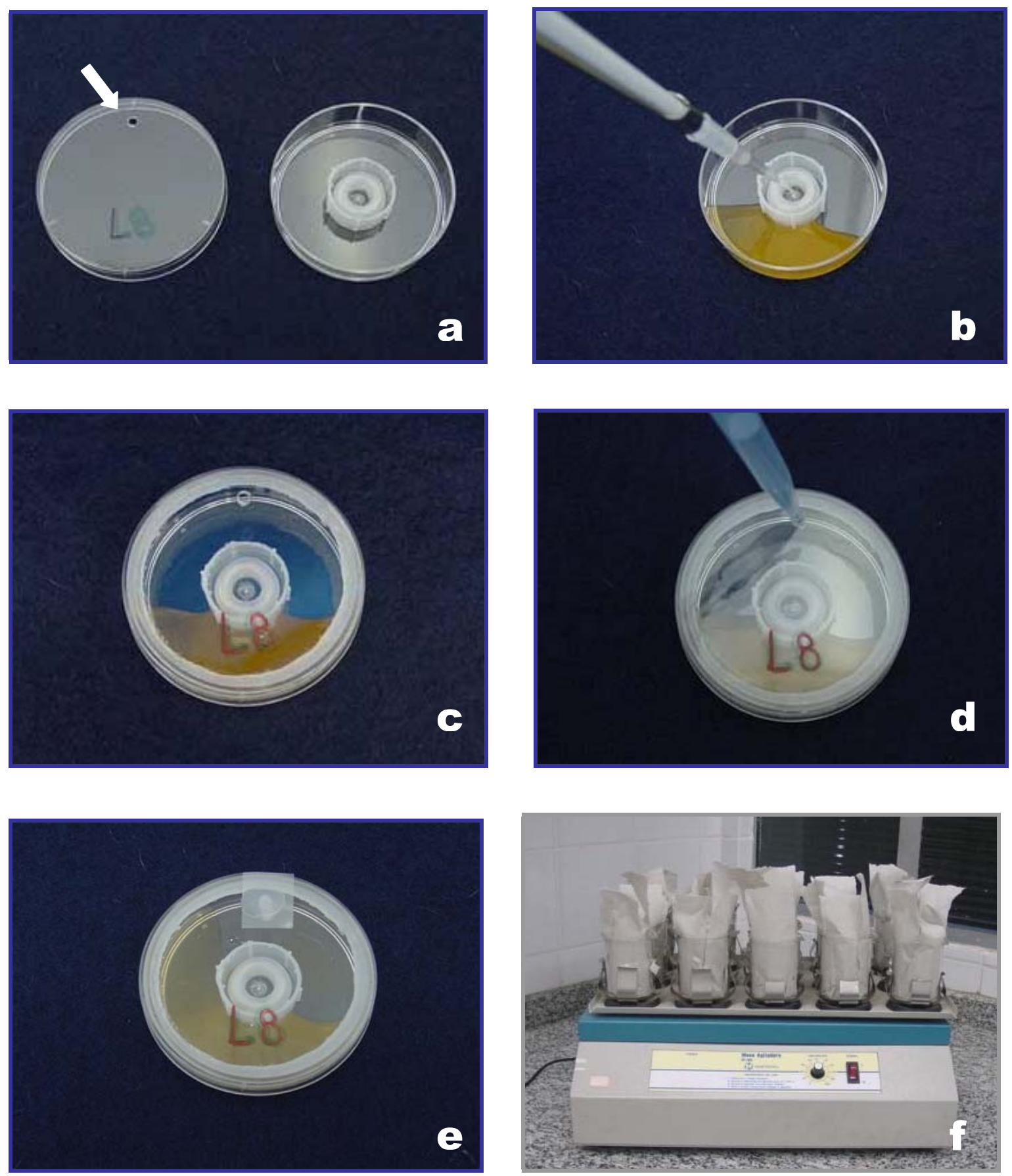

FIGURA 4.1 - a) Placa de Petri preparada; b) Adição de 0,1 mL de $\mathrm{NaOH}$ 1,65 M; c) Fechamento da placa de Petri com a tampa vaselinada; d) Colocação de $1,0 \mathrm{~mL}$ de $\mathrm{HMDS}-\mathrm{HCl}$; e) Vedamento do orifício com vaselina e parafilme; e f) Placas empilhadas, dentro de béqueres, sobre mesa agitadora 
Decorrido o tempo, as tampas de polietileno foram removidas cuidadosamente das placas de Petri, de modo a não ocorrer contaminação do líquido de seu interior com o conteúdo da placa. Após a remoção do resíduo de vaselina que a fixava na base da placa de Petri, com auxílio de palito de sorvete e gaze, as tampas de polietileno foram colocadas sobre uma bandeja de inox $\left(\right.$ Tramontina $^{\circledR}$ ) com as devidas identificações (Figura 4.2a) e levadas à estufa a $60^{\circ} \mathrm{C}$ (Estufa de cultura 502 - Orion) por 3 horas para secagem da água e formação de cristais de NaF, decorrentes das reações químicas (Figura 4.2b). Em alguns casos, pôde-se visualizar cristais de NaF formados (Figura 4.2c).

Após este período, cada tampa de polietileno foi encaixada em um tubo de ensaio de poliestireno estéril (Falcon $\mathrm{n}^{\circ}$. 2017), contendo 0,4 mL de ácido acético 0,66 M. O conjunto foi invertido e agitado vigorosamente, em agitador de tubos (modelo 251 - Fanem ${ }^{\circledR}$ ), para dissolver os cristais de NaF da tampa, que se tornaram prontos para serem dosados (Figura 4.2d). É importante observar que todas as gotículas que se espalharam pela tampa e pelo tubo, durante a agitação, foram captadas e reunidas em um único volume líquido para a leitura da dosagem de flúor (FIGURA 4.2e).

Para a análise de cada amostra, colocou-se o eletrodo em contato com o líquido, sem a presença de bolhas na interface deste com a base do eletrodo, onde ocorre a leitura, e, após a estabilização indicada no analisador de íons (Procyon, modelo SA 720), decorridos 30 segundos, registrou-se o valor apontado no visor deste aparelho, dado em milivolts (mV) (Figura 4.2f). 

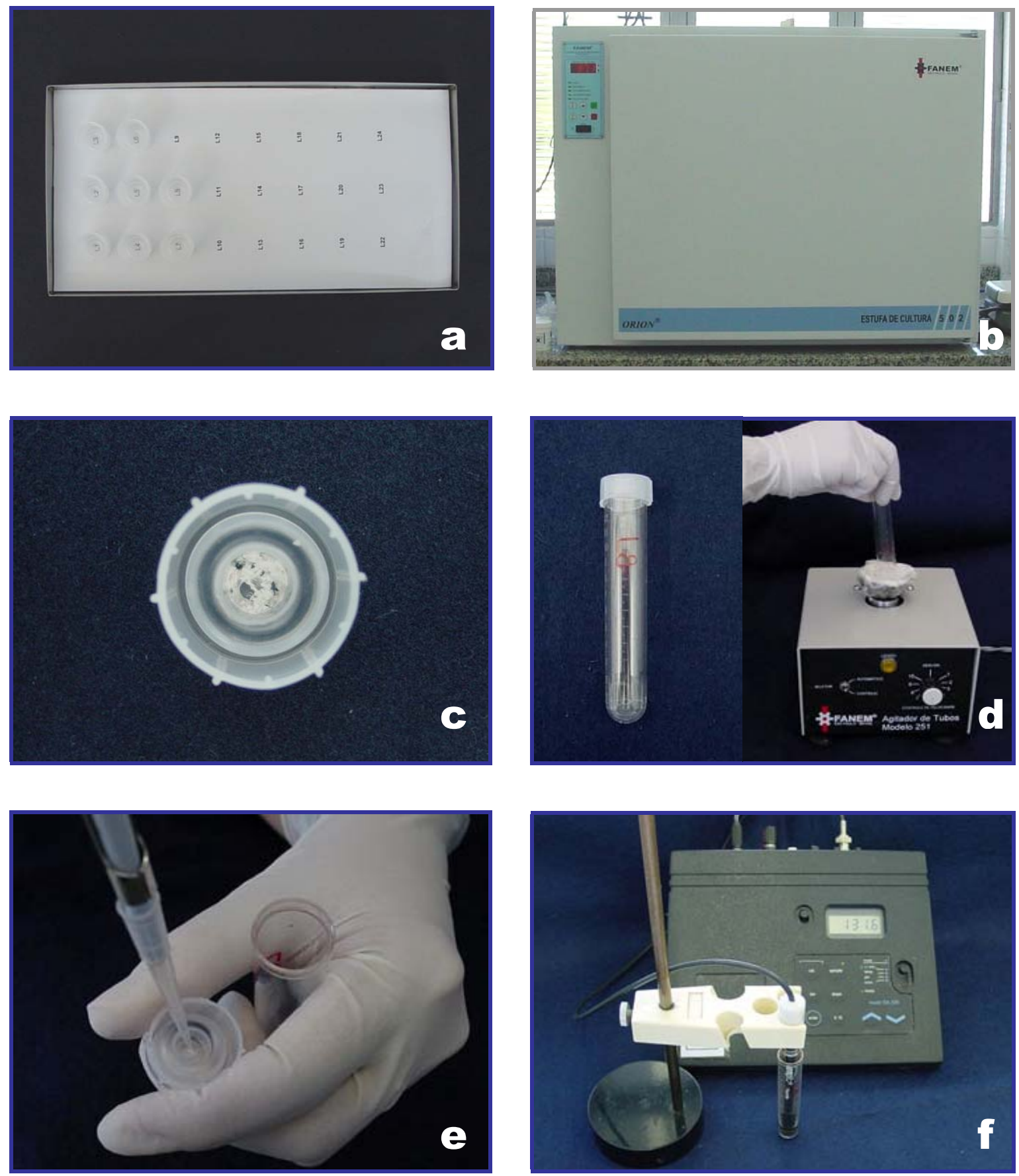

FIGURA 4.2 - a) Colocação das tampas de polietileno sobre bandeja com identificações; b) Secagem da água em estufa; c) Cristais de $\mathrm{NaF}$ formados; d) Tubo fechado, contendo 0,4 $\mathrm{mL}$ de ácido acético 0,66 $\mathrm{M} \mathrm{e}$ agitação para dissolver os cristais; e) Captação das gotículas pra formar um único volume líquido; e f) Leitura com eletrodo em contato com o líquido e resultados em $\mathrm{mV}$ 
Antes da realização das leituras, o eletrodo específico para íon flúor Orion, modelo 9609 (Orion Research, Inc.), acoplado ao analisador de íons Procyon, modelo SA 720 (Procyon Instrumentos Científica), foi primeiramente calibrado com amostras de concentrações de flúor conhecidas, fazendo-se uma curva de calibração.

As oito soluções - padrão de flúor, necessárias para a calibração do eletrodo e a confecção da curva de leitura, com concentrações variando de 0,05 a 6,4 ppm, foram obtidas a partir da diluição seriada de uma solução - estoque, contendo 100 ppm de flúor (Orion Research, Inc., $n^{\circ} .940907$ ) e preparadas para difusão juntamente com as amostras. As soluções - padrão utilizadas foram: 0,05 ppm; 0,1 ppm; 0,2 ppm; 0,4 ppm; 0,8 ppm; 1,6 ppm; 3,2 ppm e 6,4 ppm.

A curva de calibração foi feita a partir da média das leituras realizadas, em triplicata, das soluções-padrão, sendo que somente aquela com coeficiente de correlação $(r) \geq 0,99$ e porcentagem de variação entre a quantidade de flúor medida e a esperada de até $15 \%$ foi aceita. A cada 2 horas era realizado um teste para a checagem da calibração somente com a leitura da solução-padrão de flúor 0,4 ppm. A cada dia de trabalho, todo o procedimento relativo à realização da curva de calibração e checagem periódica era repetido.

O eletrodo acoplado ao analisador de íons forneceu resultados em milivolts $(\mathrm{mV})$. Sabe-se que há uma relação entre $\mathrm{mV}$ e $\log [\mathrm{F}]$ :

$$
\mathrm{mV}=\mathrm{a}-\mathrm{b}^{*} \log [\mathrm{F}]
$$


Assim, os valores de $\mathrm{mV}$ obtidos na leitura da curva de calibração foram colocados em planilha eletrônica (Programa Excel - Microsoft ${ }^{\circledR}$ ), onde foi feita uma regressão entre log $[F]$ esperado $(y)$ e $m V$ obtido $(x)$ : interceptação $=$ b e inclinação $=$ a, com uma nova equação:

$$
\log [F] \text { calculado }=a * m V+b
$$

Então, os valores obtidos em $\mathrm{mV}$ nas leituras das amostras de medicamentos foram colocados em planilha eletrônica (Programa Excel - Microsoft ${ }^{\circledR}$ ) e convertidos para ppm F (exemplo no Anexo 2).

Os medicamentos Calcigenol $^{\circledR}$ Composto B12, Calcigenol $^{\circledR}$ Irradiado, Epelin ${ }^{\circledR}$ suspensão, Hantina ${ }^{\circledR}$ suspensão oral, Kalyamon ${ }^{\circledR}$ B-12 suspensão e Pipurol ${ }^{\circledR}$ xarope ultrapassaram os valores da curva de calibração do eletrodo e foram reavaliados, após diluição de $10 \mathrm{X}$ do próprio medicamento com água deionizada, a fim de se obter valores confiáveis. Obtidas as leituras, seus valores de concentração de FT foram convertidos, multiplicando-se 10X.

\subsubsection{Determinação da concentração de Flúor Solúvel em $\mathrm{HCl}$ $0,01 \mathrm{M}(\mathrm{FS})$}

A avaliação da concentração de flúor solúvel em $\mathrm{HCl}$ 0,01 M (FS) foi uma opção viável para simular o efeito do suco gástrico ( $\mathrm{HCl} 0,01 \mathrm{M})$ no metabolismo do flúor, o que poderia dar uma idéia daquele elemento que estaria solúvel em ácido e que poderia ser absorvido na passagem especificamente pelo estômago. 
Esta análise foi realizada somente para aqueles medicamentos que apresentaram a concentração de FT a ponto de representar risco à fluorose. Portanto, adotou-se como parâmetro a faixa de ingestão de 0,05 a $0,07 \mathrm{mg} \mathrm{F/kg}$ massa corporal/dia, e considerou-se o volume máximo de medicamento possivelmente ingerido por dia, por uma criança de $12 \mathrm{~kg}$ (aproximadamente a massa de uma criança de 2 anos de idade), de acordo com a posologia indicada na bula de cada medicamento (Anexo 3). Os medicamentos que se enquadraram nesse parâmetro estão discriminados na tabela 4.14 (item material deste capítulo) e ilustrados na figura 4.3.

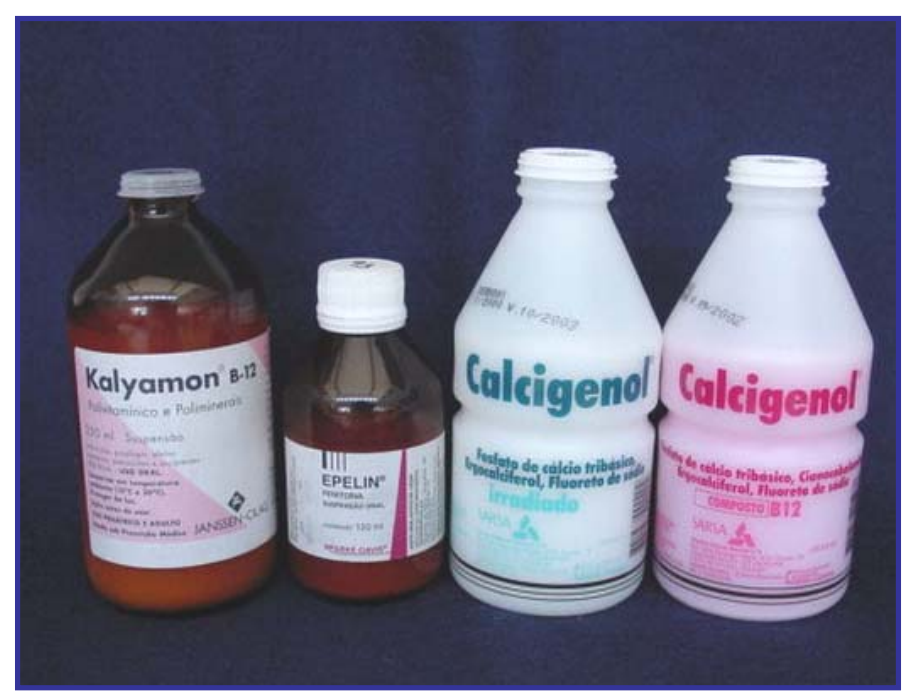

FIGURA 4.3 - Medicamentos selecionados para dosagem de FS

Cada amostra constituiu-se do medicamento diluído $5 \mathrm{X}$ com água deionizada, para garantir a leitura adequada pelo eletrodo dentro da curva de calibração. E na proporção de 1:1 (v:v), fez-se a hidrólise de flúor ionizável em HCL 0,01 M. Assim, em tubos de centrífuga ( $n^{\circ}$. 03944, Sorvall ${ }^{\circledR}$ Instruments), 3,0 mL de 
Métodos

$\mathrm{HCl}$ 0,01 $\mathrm{M}$ foram adicionados a 3,0 $\mathrm{mL}$ de amostra (Figura 4.4a). Os tubos foram fechados com tampas próprias ( $n^{\circ}$. 03268, Du Pont Company), agitados em agitador de tubos (modelo 251, Fanem ${ }^{\circledR}$ ), e mantidos em banho-maria à $37^{\circ} \mathrm{C}$ (modelo 015 , Evlab), com agitação constante, sobre a mesa agitadora orbital plana (modelo NT 145, Nova Técnica) em velocidade 2-3 por 1 hora (Figura 4.4b).

Decorrido o tempo, antes de serem submetidos à centrifugação, cada tubo foi balanceado aos pares com tubos contendo água deionizada, em balança (modelo 200 9, Record) (Figura 4.4c). Então, a centrifugação se processou a 3.000 rpm por 5 minutos (Centrífuga Sorvall Super Speed RC2-B, Sorvall ${ }^{\circledR}$ Instruments) (Figura 4.4d). Em seguida, separou-se o sobrenadante e seu volume foi registrado em proveta de poliestireno ( $\mathrm{n}^{\circ} .3663-0010$, Nalgene) (Figura 4.4e). Extraiu-se 1,0 mL do mesmo e a este, adicionou-se $0,1 \mathrm{~mL}$ de $\mathrm{NaOH} 0,1 \mathrm{M}$ e tamponou-se com 0,11 mL de TISAB III concentrado com CDTA (Orion Research, Inc.) para a realização das leituras da concentração de FS em béqueres de poliestireno ( $n^{\circ} .50$, Injeplast) (Figura 4.4f).

A análise de FS foi obtida através do método direto. Utilizou-se também o eletrodo específico para íon flúor Orion, modelo 9609 (Orion Research, Inc.), acoplado ao analisador de íons Procyon, modelo SA 720 (Procyon Instrumentos Científica).

As leituras, obtidas em $\mathrm{mV}$, foram convertidas para ppm $\mathrm{F}$, através de uma planilha de dados (Microsoft ${ }^{\circledR}-$ Excel), onde também se converteu a concentração de FS para 1,0 mL de cada medicamento, lembrando que nesta análise, utilizou-se 3,0 $\mathrm{mL}$ de cada amostra de medicamento diluído previamente 5X (Anexo 4). 

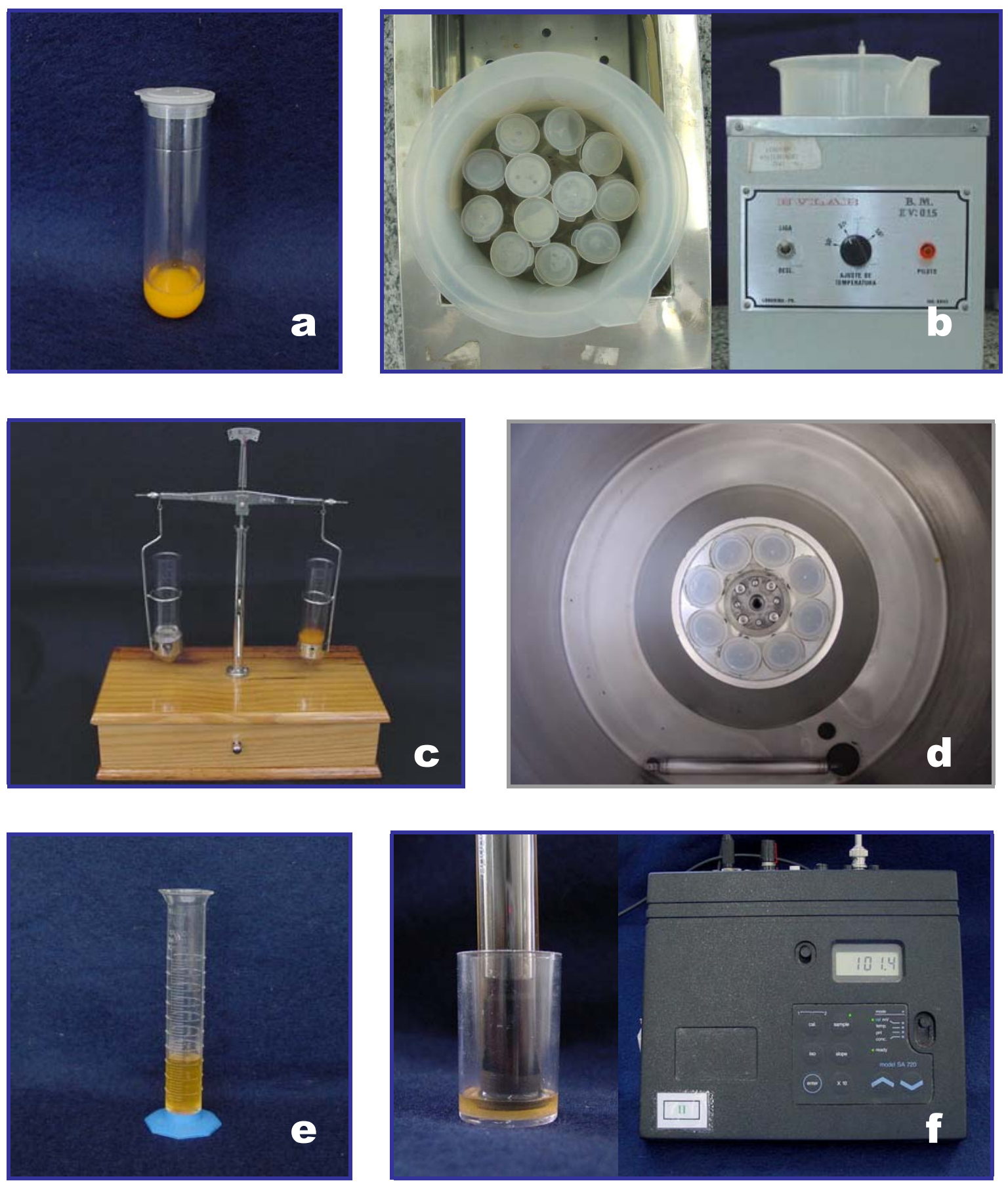

FIGURA 4.4 - a) Tubo de centrífuga preparado; b) Tubos dentro de béquer de polietileno, mantidos em banho-maria à $37^{\circ} \mathrm{C}$, com agitação constante; c) Balanceamento dos tubos aos pares; d) Centrifugação a 3.000 rpm por 5 minutos; e) Registro do volume do sobrenadante; e f) Leitura de FS pelo método direto e resultado obtido em $\mathrm{mV}$ 
As soluções - padrão de flúor, com concentrações variando de 0,05 a 6,4 ppm, foram obtidas a partir da diluição seriada de uma solução - estoque, contendo 100 ppm de flúor (Orion Research, Inc., $\mathrm{n}^{\circ} .940907$ ) e lidas pelo mesmo método direto, previamente às amostras. Porém, para tanto, adicionou-se a 0,5 $\mathrm{mL}$ de cada solução-padrão, 0,5 mL de $\mathrm{HCl} 0,02 \mathrm{M} ; 0,1 \mathrm{~mL}$ de $\mathrm{NaOH}$ 0,1 M; e 0,11 mL de TISAB III. Para o blank, adicionou-se a $1,0 \mathrm{~mL}$ de $\mathrm{HCl} 0,01 \mathrm{M}, 0,1 \mathrm{~mL}$ de $\mathrm{NaOH} 0,1 \mathrm{M}$; e $0,11 \mathrm{~mL}$ de TISAB III.

A curva de calibração foi feita, da mesma forma como se procedeu para a determinação de FT, a partir da média das leituras realizadas em triplicata, das soluções-padrão, sendo que somente aquela com coeficiente de correlação $(r) \geq$ 0,99 e porcentagem de variação entre a quantidade de flúor medida e a esperada de até $15 \%$ foi aceita. A cada 2 horas era realizado um teste para a checagem da calibração somente com a leitura da solução-padrão de flúor 0,4 ppm. 


\subsubsection{Validação das análises de FT e FS}

As análises definitivas de FT e FS desta pesquisa iniciaram-se somente após a realização de um estudo piloto, de modo a padronizar os métodos para ambas as análises e garantir seus resultados.

Neste estudo piloto, definiu-se que a leitura de uma amostra simples de cada medicamento seria suficiente para proporcionar um resultado confiável, tanto para FT como para FS, sendo que não houve diferença em casas centesimais, entre os valores convertidos em ppm das leituras em triplicata de um grupo de 15 medicamentos (Anexo 2).

Também para a realização deste teste piloto e de todos os testes válidos desta pesquisa, foram preparadas as curvas de calibração empregando-se as diferentes diluições do flúor. Além disso, o mesmo esquema de trabalho já descrito, relativo às checagens periódicas da calibração, do nível de correlação e da variação pré-determinados para as curvas, foi respeitado.

\subsubsection{Previsão de risco à fluorose dentária}

Para pesquisar os medicamentos que pudessem ser estimados ou sugeridos como possível fator de risco ao desenvolvimento da fluorose dentária, fezse um cálculo, por amostra, entre o resultado da concentração de FS do medicamento e o consumo diário máximo do medicamento, conforme descrito na 
Métodos

posologia da própria bula, tomando-se como base a massa de uma criança de 2 anos, que é aproximadamente de $12 \mathrm{~kg}$, e a comparação com a faixa de dose "segura" de flúor consumido, aceita neste estudo, que é de até 0,05 a 0,07 mg de F/kg massa corporal/dia, lembrando que $1 \mathrm{ppm}$ de $\mathrm{F}$ equivale a $1 \mu \mathrm{g}$ de $\mathrm{F} / \mathrm{mL}$. Isto porque a ingestão de flúor é mais importante para crianças em idades que estão em risco de desenvolver fluorose em seus dentes permanentes, sobretudo nos dentes anteriores.

\subsubsection{Análise dos resultados}

Os resultados obtidos foram dispostos em gráficos, quadros e tabelas, para análise descritiva. 
5 RESULTADOS 


\section{RESULTADOS}

\subsection{DOSAGEM DA CONCENTRAÇÃO DE FT}

A análise dos dados da dosagem bioquímica de FT dos medicamentos permitiu constatar que 113 ou $99,12 \%$ dos medicamentos apresentaram flúor em sua composição, apesar da maior parte (91 ou 79,8\%) ter demonstrado valores de FT inferiores a 0,1 ppm. Alguns medicamentos concentraram-se nas faixas de 0,1 a 1,0 ppm (14 ou $12,3 \%$ ) e de 1,0 a 10,0 ppm (4 ou $3,5 \%$ ) e, 5 ou $4,4 \%$ apresentaram-se superiores a 10,0 ppm (Figura 5.1).
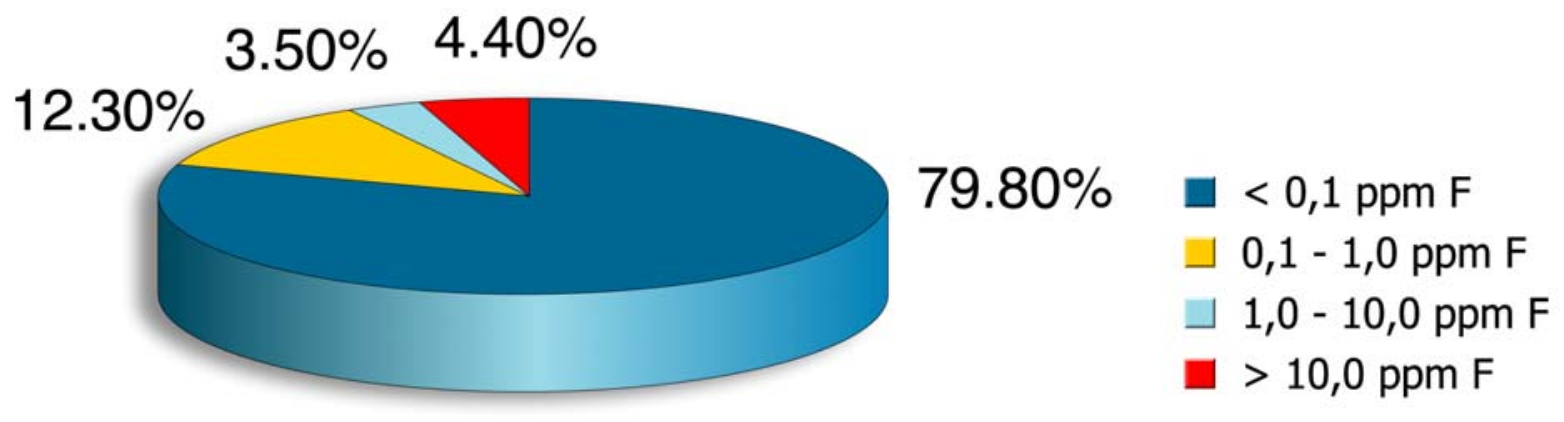

FIGURA 5.1 - Freqüência de distribuição de níveis de FT nos medicamentos 
Os resultados, em ppm, da dosagem da concentração de FT dos medicamentos encontram-se nas figuras 5.2 e 5.3.

\begin{tabular}{|c|c|c|c|c|}
\hline ppm (FT) & \multicolumn{4}{|c|}{ Medicamentos } \\
\hline 97,80 & \multicolumn{4}{|c|}{ Kalyamon® B-12 } \\
\hline 57,89 & \multicolumn{4}{|l|}{ Epelin® } \\
\hline 51,83 & \multicolumn{4}{|c|}{ Calcigenol Irradiado } \\
\hline 25,62 & \multicolumn{4}{|c|}{ Calcigenol Composto B12 } \\
\hline 16,25 & \multicolumn{4}{|l|}{ Hantina ${ }^{\circledR}$} \\
\hline 7,11 & \multicolumn{4}{|l|}{ Pipurol® } \\
\hline 5,16 & \multicolumn{4}{|c|}{ Neutrofer ${ }^{\circledR} 250 \mathrm{mg} / \mathrm{mL}$} \\
\hline 3,08 & \multicolumn{4}{|c|}{ Kaomagma ${ }^{\circledR}$} \\
\hline 1,93 & \multicolumn{4}{|c|}{ Nutri-Ped® } \\
\hline 0,79 & \multicolumn{4}{|l|}{ Nonavit } \\
\hline 0,53 & \multicolumn{4}{|c|}{ Clavulin® BD 400mg } \\
\hline 0,38 & \multicolumn{4}{|c|}{ Neutrofer® fólico } \\
\hline 0,15 & \multicolumn{4}{|l|}{ Cobactin ${ }^{\circledR}$} \\
\hline 0,13 & Flogonac & Rhodia Farma-Prednisolona & Bricanyl® & Seki® \\
\hline 0,12 & \multicolumn{4}{|l|}{ Septiolan } \\
\hline
\end{tabular}

\section{Legenda}

Analgésicos antiinflamatórios antitérmicos

Antibióticos

Sulfas

Para nefropatias

Anti-histamínicos

Anticonvulsivantes

Corticosteróides

Broncodilatadores

Para cardiopatias

Mucolíticos

Antitussígenos

Para gastroenteropatias

Suplementos vitamínicos

\section{$<0,1 \mathrm{ppm} F \quad \square 0,1-1,0 \mathrm{ppm} \mathrm{F}$ $1,0-10,0 \mathrm{ppm} F \quad \square>10,0 \mathrm{ppm} \mathrm{F}$}

FIGURA 5.2 - Valores das concentrações de FT dos medicamentos maiores que 0,1 ppm 


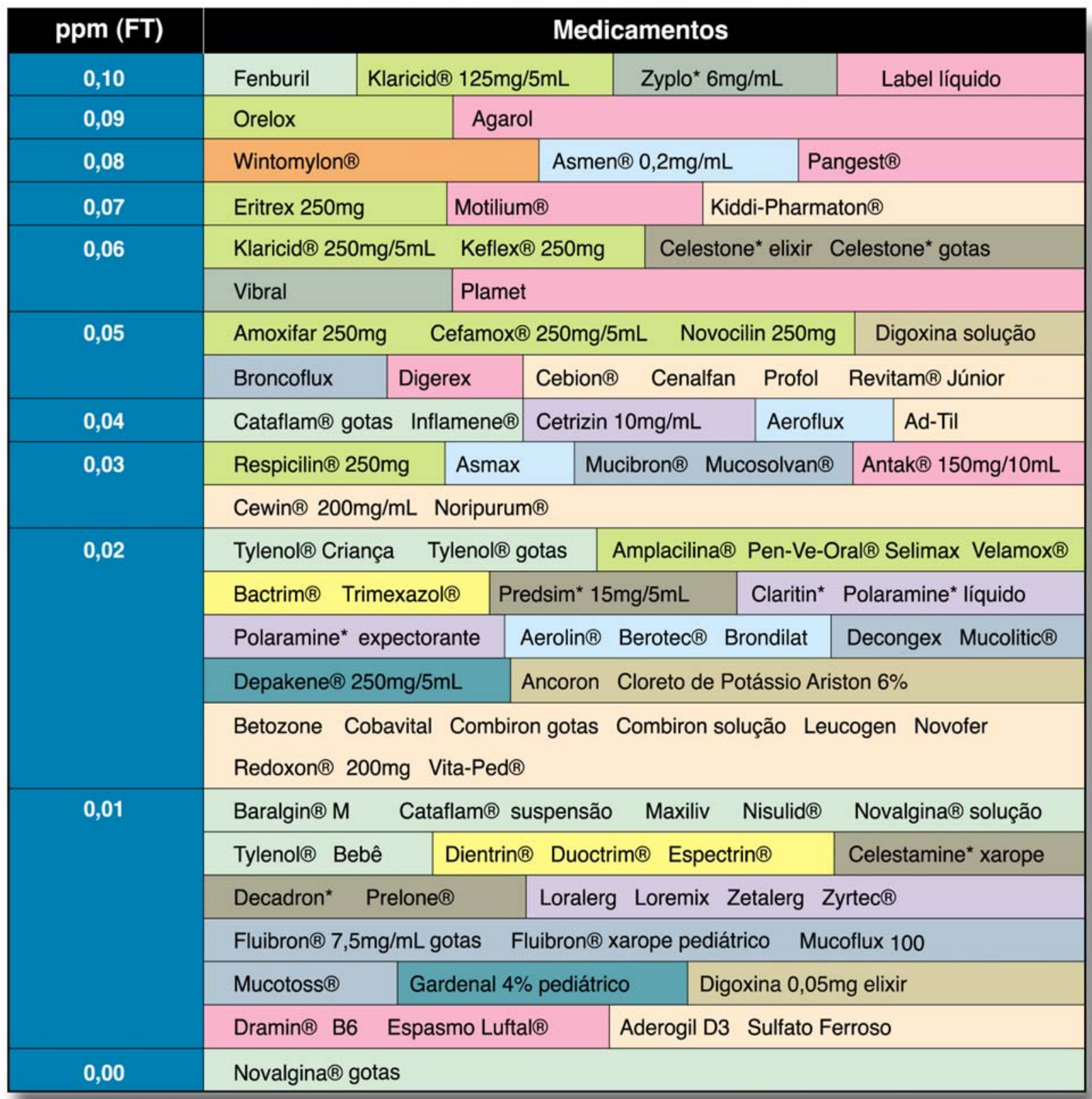

FIGURA 5.3 - Valores das concentrações de FT dos medicamentos menores que $0,1 \mathrm{ppm}$ 
Conforme foi mostrado nas duas figuras anteriores, as concentrações de FT dos medicamentos variaram de 0,00 a 97,80 ppm.

A partir desses resultados, selecionou-se para a dosagem de FS, os medicamentos que apresentaram concentração de FT a ponto de representar risco à fluorose. Os mesmos estão relacionados a seguir (Tabela 5.1).

TABELA 5.1 - Estimativa do consumo diário de F a partir de FT e seleção dos medicamentos para a dosagem de FS

\begin{tabular}{|c|c|c|c|c|}
\hline \multirow[b]{2}{*}{ Medicamento } & \multicolumn{4}{|c|}{ Consumo diário } \\
\hline & $\mathrm{mL}^{*}$ & {$[\mathrm{FT}]^{\dagger}$} & Ingestão Total $^{\ddagger}$ & mg F/kg de massa ${ }^{\S}$ \\
\hline Kalyamon ${ }^{\circledR}$ B-12 & 30 & 0,09780 & 2,934 & 0,244 \\
\hline Epelin $^{\circledR}$ & 15 & 0,05789 & 0,868 & 0,072 \\
\hline Calcigenol $^{\circledR}$ Irradiado & 20 & 0,05183 & 1,036 & 0,086 \\
\hline Calcigenol ${ }^{\circledR}$ Composto B12 & 30 & 0,02562 & 0,768 & 0,064 \\
\hline
\end{tabular}

* Posologia do medicamento recomendada para criança com $12 \mathrm{~kg}$

$\dagger 1 \mathrm{ppm}=1 \mu \mathrm{g} / \mathrm{mL}=0,001 \mathrm{mg} / \mathrm{mL}$

${ }^{\ddagger} \mathrm{mL}$. [FT] = Ingestão total $(\mathrm{mg} / \mathrm{mL})$

$\S$ Quantidade diária de FT ingerida para efeito de comparação com a dose "segura" (0,05 a 0,07 mg F / kg massa corporal / dia)

\subsection{DOSAGEM DA CONCENTRAÇÃO DE FS}

As concentrações de FS obtidas dos 4 medicamentos que apresentaram FT igual ou superior à faixa de segurança estipulada para uma criança de $12 \mathrm{~kg}$ podem ser vistas no próximo gráfico (Figura 5.4), juntamente com seus respectivos valores 
Resultados

de FT, de modo a ser notada uma diferença existente entre ambas as concentrações.

Em todos os casos houve redução na concentração de flúor, de FT para FS, sendo que esta diferença variou $98,07 \%$ para Kalyamon $^{\circledR}$ B-12, 35,82\% para Epelin $^{\circledR}, 88,46 \%$ para Calcigenol ${ }^{\circledR}$ Irradiado, e $86,02 \%$ para Calcigenol ${ }^{\circledR}$ Composto B12.

ppmF

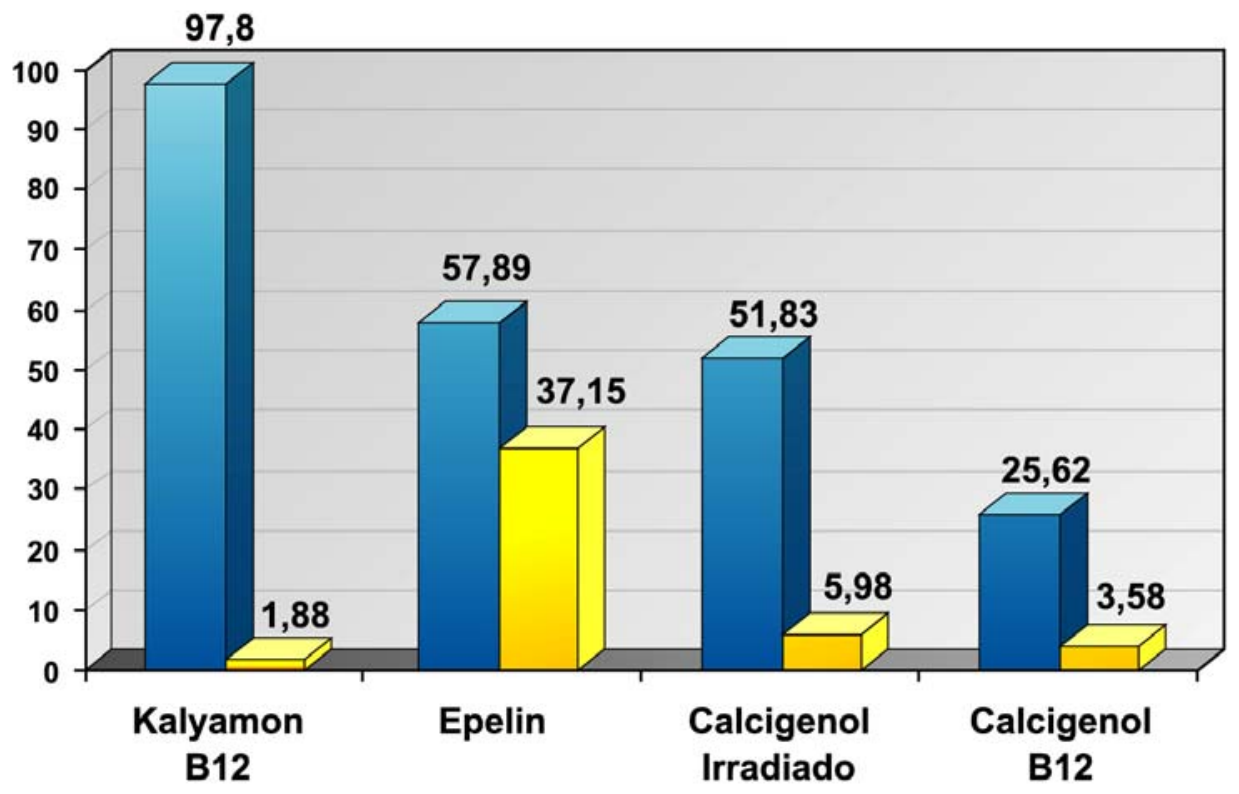

FIGURA 5.4 - Valores das concentrações de FT e FS 


\subsection{PREVISÃO DE RISCO À FLUOROSE DENTÁRIA}

Ao se calcular, por medicamento, o volume consumido diariamente com a concentração de FS obtida, têm-se valores de 0,004 a 0,046 mg F / kg massa corporal / dia (Tabela 5.2), que representam uma quantidade de flúor proveniente apenas da ingestão de cada medicamento e possível de ser absorvida no estômago.

TABELA 5.2 - Estimativa do consumo diário de F a partir dos valores obtidos de FS

\begin{tabular}{|c|c|c|c|c|}
\hline \multirow[b]{2}{*}{ Medicamento } & \multicolumn{4}{|c|}{ Consumo diário } \\
\hline & $\mathrm{mL}^{*}$ & {$[\mathbf{F S}]^{\dagger}$} & Ingestão Total $^{\ddagger}$ & mg F/kg de massa ${ }^{\S}$ \\
\hline Kalyamon ${ }^{\circledR}$ B-12 & 30 & 0,0018 & 0,054 & 0,004 \\
\hline Epelin ${ }^{\circledR}$ & 15 & 0,0371 & 0,556 & 0,046 \\
\hline Calcigenol ${ }^{\circledR}$ Irradiado & 20 & 0,0059 & 0,118 & 0,009 \\
\hline Calcigenol ${ }^{\circledR}$ Composto B12 & 30 & 0,0035 & 0,105 & 0,008 \\
\hline
\end{tabular}

* Posologia do medicamento recomendada para criança com $12 \mathrm{~kg}$

$\dagger 1 \mathrm{ppm}=1 \mu \mathrm{g} / \mathrm{mL}=0,001 \mathrm{mg} / \mathrm{mL}$

${ }^{\ddagger} \mathrm{mL}$. [FS] = Ingestão total $(\mathrm{mg} / \mathrm{mL})$

$\S$ Quantidade diária de FS ingerida para efeito de comparação com a dose "segura" (0,05 a 0,07 mg F / kg massa corporal / dia)

Neste cenário, considerando a ingestão de flúor por dia, somente a partir de cada medicamento individualmente, nenhum deles superaria a faixa de 0,05 a 0,07 $\mathrm{mg} / \mathrm{kg}$ massa corporal/dia, que tem sido sugerida como limite para a exposição "segura" ao flúor. Entretanto, o Epelin ${ }^{\circledR}$ aproximou-se estreitamente do limite inferior desta faixa, podendo contribuir com $65,7 \%$ em relação ao limite de 0,07 mg F/kg massa corporal/dia ou até $92 \%$ em relação ao limite de $0,05 \mathrm{mg} \mathrm{F} / \mathrm{kg}$ massa 
Resultados

corporal/dia, quantidade essa ainda tolerada, porém importante por poder estar biodisponível e acumulada no organismo. 
6 DISCUSSÃO 


\section{DISCUSSÃO}

A literatura demonstra que nos últimos anos vêm ocorrendo importantes mudanças a respeito do uso do flúor em Odontologia, em termos de benefícios e/ou de riscos ${ }^{171}$. Como se observa um aumento na prevalência da fluorose dentária, em comunidades com água fluoretada ou não, simultaneamente ao declínio na prevalência da cárie dentária nas três últimas décadas ${ }^{1}$, 20, 28, 30, 61, 72, 81, 84, 87, 117, 128, 134, 148, 162, 181, 183 , estima-se que a população, de modo global, está se aproximando e/ou ultrapassando o limite "seguro" de ingestão de flúor ${ }^{19,} 100$ e muitas possíveis fontes de flúor estão sendo avaliadas.

As crianças com problemas de saúde crônicos compõem um grupo especial, que merece atenção quanto aos problemas de fluorose. A vida diária pode ser mais ou menos afetada, tanto pela doença em si, quanto pela medicação e pelo tratamento ${ }^{91}$. Os diferentes graus de comprometimento, desde asma até transplante de medula, e variados protocolos terapêuticos, requerem o uso diário de uma série de medicamentos, seja de maneira simples ou associados, até mesmo várias vezes ao dia, por um longo período de tempo ou com recorrência ${ }^{41}$, que precisam ser avaliados quanto ao teor de flúor. Os medicamentos prescritos são na grande maioria apresentados na forma líquida e têm sido associados, por inúmeros estudos, com a maior ocorrência da cárie dentária em quem os utiliza regularmente ${ }^{41,53,145,}$ 146,154, por conter principalmente a sacarose em sua composição e pela sua relação 
Discussão

com o fator tempo. Quanto à presença de flúor, há uma falta de conhecimento documentado na literatura médico-odontológica.

A avaliação de CASTRO et al. ${ }^{25}$ (2000) confirmou a pertinência em se pesquisar a presença de flúor na composição de medicamentos pediátricos, que podem ser administrados para crianças em idade de risco de desenvolver fluorose. Ao relacionar a presença de fluorose com fatores de risco, a história de ingestão de vitaminas contendo flúor foi significante com relação à presença de fluorose $(p=0,002$; teste de Fischer), assim como a história relatada de ingestão de dentifrício $(p=0,0009 ;$ teste de Fischer).

Na presente pesquisa, procurou-se avaliar uma gama de medicamentos pediátricos disponíveis no mercado nacional. A entrevista com médicos que tratam de crianças com problemas de saúde crônicos foi requerida pela necessidade de identificar algumas patologias crônicas mais relevantes e selecionar os medicamentos mais comumente prescritos para esses casos. Através da avaliação da concentração de flúor total, foi constatada a ausência de flúor somente em uma (Novalgina ${ }^{\circledR}$ gotas) das 114 amostras de medicamentos. Apesar de $79,8 \%$ deles apresentarem na composição valores menores que 0,1 ppm $\mathrm{F}$, houve uma grande variação, com o Kalyamon ${ }^{\circledR}$ B-12 atingindo um teor surpreendente de 97,8 ppm F. Alguns medicamentos concentraram-se em faixas preocupantes de 0,1 a 1,0 ppm $\mathrm{F}$ $(12,3 \%)$ e de 1,0 a 10,0 ppm $\mathrm{F}(3,5 \%)$, podendo alcançar valores maiores que 10,0 ppm F $(4,4 \%)$.

O método de TAVES $^{163}$ é um processo de extração de flúor de amostras para que sua concentração seja determinada. Utiliza o Ácido Clorídrico $(\mathrm{HCl})$ 
Discussão

saturado de HMDS (HMDS-HCl) e segue o princípio de que este HMDS-HCl, em contato com uma solução, é muito reativo com o flúor da mesma. $\mathrm{O} \mathrm{HCl}$ extrai o flúor, e o HMDS provoca a formação de um composto volátil, o trimetilfluorsilano, que será captado pelo $\mathrm{NaOH}$ da tampa central de polietileno, formando $\mathrm{NaF}$ e água. Este $\mathrm{NaF}$ é que será quantificado através do eletrodo.

Este método é rotineiramente utilizado para amostras em que o flúor possa estar unido, separando-o e isolando-o de outros componentes da mesma que podem afetar a sensibilidade do eletrodo de íons flúor ${ }^{88}$. Foi adotado neste estudo, pois quando se desconhece a concentração de flúor na amostra a ser estudada, a difusão facilitada por HMDS serve para concentrar esse elemento químico nela, mesmo que em pequenas quantidades, antes da análise final utilizando o eletrodo.

\section{Em 1981, a ASSOCIATION OF OFFICIAL ANALYTICAL CHEMISTS ${ }^{31}$ o} recomendou como o método de separação para determinar o flúor em alimentos infantis, e em 1986, SINGER; OPHAUG ${ }^{155}$ concluíram que era o mais simples pelo menos para análise de flúor em alimentos, sendo considerado reproduzível e preciso com menos que $8 \%$ de erro ${ }^{172}$.

Os medicamentos Calcigenol ${ }^{\circledR}$ Composto B12, Calcigenol ${ }^{\circledR}$ Irradiado, Epelin ${ }^{\circledR}$ suspensão e Kalyamon ${ }^{\circledast}$ B-12 suspensão apresentaram concentrações de FT elevadas (Tabela 5.1), gerando a necessidade de uma avaliação diferenciada, para determinar se os mesmos representariam um risco à fluorose.

O Epelin ${ }^{\circledast}$ suspensão é um anticonvulsivante, que tem como vantagens além da efetividade terapêutica, o baixo custo. Já foi muito utilizado, porém atualmente evita-se sua prescrição devido aos efeitos colaterais reconhecidos de hipertricose e 
Discussão

hiperplasia gengival, por ser à base de difenil hidantoína (ou fenitoína). Quando a família assume os custos, vem sendo substituído pela carbamazepina, como por exemplo, o Tegretol ${ }^{\circledR}$ (nome comercial). O serviço de saúde pública vem buscando disponibilizar este medicamento aos pacientes, mas nem sempre é possível.

Não se sabe ainda o motivo da presença de flúor na composição do Epelin ${ }^{\circledast}$. De acordo com o fabricante, durante o processo de fabricação é usada a fenitoína na forma pura e a água é deionizada. Em contatos posteriores, o mesmo comunicou não haver encontrado a presença de flúor na mesma amostra do medicamento testada neste estudo. Contudo, não foi informada qual a metodologia empregada no teste realizado.

Já o Calcigenol ${ }^{\circledast}{\text { Composto B12, } \text { Calcigenol }^{\circledR} \text { Irradiado e Kalyamon }}^{\circledast}$ B-12 suspensão são polivitamínicos, que propositadamente incluem flúor na composição. Quando questionado sobre a razão da inclusão das quantidades de flúor presentes na fórmula, o fabricante dos dois medicamentos sob a denominação "Calcigenol ${ }^{\circledast "}$ não forneceu nenhuma informação, alegando segredo industrial. De acordo com informações dadas pelo fabricante do Kalyamon ${ }^{\circledR} B-12$, isso é feito "com base nas necessidades diárias das crianças, conforme recomendado pelo Ministério da Saúde". As concentrações de flúor informadas nos rótulos do Calcigenol ${ }^{\circledR}$ Composto B12 e do Calcigeno ${ }^{\circledast}$ Irradiado são respectivamente de 50 ppm F e 100 ppm F, diferindo daquelas encontradas neste trabalho (25,62 ppm F e 51,83 ppm F). No entanto, para o Kalyamon ${ }^{\oplus}$ B-12 a concentração de flúor informada verbalmente pelo fabricante (20 ppm F) coincide com a indicada na bula do medicamento, a qual é bem inferior daquela encontrada neste estudo ( $97,8 \mathrm{ppm})$. 
Esses polivitamínicos são amplamente utilizados como complementos alimentares, suplementos de flúor e fortificantes desde idades bastante precoces, como uma semana de vida pós-natal, independentemente da criança estar doente ou não. Mas, segundo normas recentes, sua recomendação como suplementos fluoretados só deveria iniciar-se aos 6 meses de idade e quando a água apresentasse menos que 0,3 ppm F. Cuidados com relação às doses também devem ser revistas, sendo necessários ajustes nas posologias recomendadas pelos fabricantes ${ }^{171}$. Na maioria das vezes seu uso está relacionado ao conhecimento popular e às práticas familiares, ambos passados de geração em geração, de pais para filhos, pois estão no mercado há muito tempo. A prescrição correta de suplementos no Brasil é inviável com o agravante de serem produtos de venda livre nas prateleiras das farmácias e não haver regulamentação com relação aos produtos do mercado ${ }^{171}$. Mesmo na ausência de um quadro de carência nutricional, é amplamente difundido na população que vitaminas ajudam no melhor crescimento e desenvolvimento da criança.

Porém, nem todo flúor que é ingerido será absorvido. O mineral pode estar presente através de formas químicas diferentes que estão relacionadas com a capacidade de absorção pelo organismo, seja no estômago e no intestino, e isso resultará em uma dada biodisponibilidade. Muitas das ingestões de flúor podem estar sendo sobre-estimadas ${ }^{23}$.

A absorção de flúor no estômago (20-25\%) ${ }^{121}$, apesar de ser menor que a no intestino delgado $(80 \%)^{112,121,181}$, tem uma relevante implicação na sua toxicidade, e decidiu-se que era oportuno pesquisar a biodisponibilidade desse 
Discussão

elemento, considerando-se as modificações que ele sofreria no estômago, em contato com o suco gástrico. A avaliação da concentração de flúor solúvel em $\mathrm{HCl}$ 0,01 M foi uma opção viável para simular o efeito do suco gástrico $(\mathrm{HCl} 0,01 \mathrm{M})$ na hidrólise ácida do composto de flúor. Isto poderia dar uma idéia daquele elemento que, teoricamente, estaria disponível para a absorção gástrica e distribuição pelo organismo, com enfoque aos mecanismos envolvidos na fluorose. Este modelo de estudo tem sido adotado por outros trabalhos ${ }^{59,103,171}$. Entretanto, ele não reproduz as demais condições gastrointestinais ou metabólicas.

Verificou-se uma redução na concentração de flúor, de FT para FS, para os medicamentos Kalyamon ${ }^{\circledR}$ B-12 $(98,07 \%)$, Epelin ${ }^{\circledR}(35,82 \%)$, Calcigenol ${ }^{\circledR}$ Irradiado $(88,46 \%)$, e Calcigenol $^{\circledR}$ Composto B12 $(86,02 \%)$. Sendo assim, um teor de flúor maior que o detectado por este método pode ser absorvido no intestino delgado, e conseqüentemente existe uma limitação inerente, que não deve ser desconsiderada. Por outro lado, quando os níveis de flúor detectados por ele ultrapassarem o nível de ingestão "segura", deve-se lembrar que o risco à fluorose é sério.

Com o objetivo de ilustrar informações cientificamente conduzidas ${ }^{25}$ e com referência a este raciocínio, relata-se um caso interessante ocorrido na Clínica de Odontopediatria da Faculdade de Odontologia de Bauru - USP, quando uma criança de 7 anos de idade procurou atendimento devido às manchas brancas nos dentes molares decíduos e anteriores permanentes, diagnosticadas clinicamente como fluorose. Durante a anamnese, a mãe relatou que a criança nasceu com anemia e após uma semana de vida a pediatra receitou Calcigenol, Aderogil e Sulfato Ferroso. Estes dois últimos foram consumidos até o primeiro ano de vida, enquanto o 
Discussão

Calcigenol foi mantido até os 5 anos de idade. Desde o nascimento a criança vivia em Bauru - SP, com concentração média de flúor na água de abastecimento público de $0,7 \mathrm{ppm}$, e passou a utilizar o dentifrício fluoretado na escovação somente aos 5 anos de idade. Até o momento da entrevista não havia participado de nenhum programa preventivo com o uso de flúor. Esse quadro levantou uma suspeita do envolvimento do Calcigenol. Conforme o relato da mãe, não foi possível precisar qual o tipo de Calcigenol prescrito à criança, nem a posologia empregada.

A redução da biodisponibilidade do flúor verificada nos polivitamínicos (Figura 5.4), que são também enriquecidos com sais minerais, pode ter ocorrido devido provavelmente à ligação com sais de cálcio ${ }^{60}$. Sabe-se que é necessário que o cálcio e o flúor quando oferecidos de forma combinada se apresentem sob a forma de compostos compatíveis ${ }^{171}$. Considera-se que o cálcio reduz a retenção de flúor pelo organismo em aproximadamente $40 \%$. Outros elementos químicos como o magnésio e o alumínio também são capazes de diminuir a absorção de flúor. No Brasil, a maioria dos compostos apresenta-se sob a forma de $\mathrm{NaF}$ e o cálcio sob a forma de carbonato ou fosfato de cálcio. Esta combinação forma compostos insolúveis o que possivelmente explicaria a diminuição porcentual de flúor solúvel encontrado nos medicamentos ${ }^{171}$.

Com relação ao anticonvulsivante Epelin ${ }^{\circledR}$, a redução da biodisponibilidade do flúor foi bem menor em comparação àquela obtida com os polivitamínicos (Figura 5.4). Na bula deste medicamento não consta a presença de flúor e tampouco isso foi confirmado pelo fabricante. O resultado obtido, no entanto, é claro e confiável, 
Discussão

atestando a presença daquele elemento químico e provavelmente, sem uma interferência marcante de alguma substância que pudesse se complexar a ele.

Determinações prévias da ingestão dietética de flúor por bebês e crianças têm sido feitas primeiramente pela avaliação da concentração de flúor nos principais alimentos infantis e, multiplicando-se esses valores pelas estimativas da quantidade de cada alimento consumida diariamente ${ }^{71,148}$. Assim, neste estudo, optou-se por avaliar as concentrações de FT e de FS de cada medicamento e multiplicá-los pelo volume consumido por dia como recomendado na posologia da própria bula.

Para a previsão de risco à fluorose atribuído por si só ao consumo de cada um dos medicamentos, adotou-se como parâmetro $12 \mathrm{~kg}$ como sendo a massa de uma criança de 2 anos, independentemente do sexo, pois de acordo com as tabelas de acompanhamento do desenvolvimento pôndero-estatural utilizadas no país por pediatras, nutricionistas e outros profissionais que trabalham com crianças, essa massa aproximadamente corresponde ao porcentil 50, isto é, um ponto que representa a média $(50 \%)$ das crianças nesta idade, apesar de ser ligeiramente superior para os meninos, conforme dados da literatura ${ }^{105,116,126}$.

A idade de 2 anos foi escolhida, uma vez que se aproxima do período crítico de risco à fluorose dos dentes anteriores permanentes, que em adicional têm maior valor estético, apesar de todos os dentes estarem suscetíveis à fluorose durante todo o período da amelogênese ${ }^{47,49,29,181}$.

Há dificuldades em se estimar a dosagem diária de flúor que pode resultar em fluorose, pois são várias as fontes de flúor, nem todas realmente conhecidas, nem todo flúor que é ingerido será absorvido, e o efeito não se manifesta 
clinicamente a curto prazo ${ }^{77}$. Qualquer estimativa é apenas um número aproximado $^{117}$. E a faixa de 0,05 a $0,07 \mathrm{mg} \mathrm{F} / \mathrm{kg}$ massa corporal/dia pareceu ser um limite de ingestão de flúor mais aceito, pelo menos para evitar formas graves de

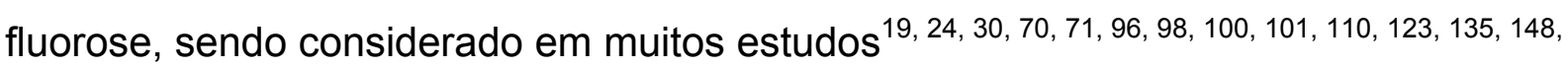
153

Nas condições experimentais deste estudo, considerando-se apenas os resultados obtidos para FS, enquanto o Kalyamon ${ }^{\circledR}$ B-12 $(0,004 \mathrm{mg}$ F/kg massa corporal/dia), Calcigenol ${ }^{\circledR}$ Composto B12 (0,008mg F/kg massa corporal/dia) e Calcigenol ${ }^{\circledR}$ Irradiado $(0,009 \mathrm{mg} \mathrm{F} / \mathrm{kg}$ massa corporal/dia), podem contribuir menos para a ingestão diária de flúor quando consumidos individualmente, o medicamento Epelin $^{\circledR}(0,046 \mathrm{mg} \mathrm{F} / \mathrm{kg}$ massa corporal/dia) pode fornecer de $65,7 \%$ até $92 \%$ da quantidade de flúor biodisponível ainda tolerada para uma criança de 2 anos, com cerca de $12 \mathrm{~kg}$. Por essa razão, ele pode ser um importante fator de risco para a fluorose, especialmente quando combinado com outras fontes de flúor. No entanto, sua função principal de anticonvulsivante é que ditará seu emprego em crianças. Assim, um alerta ao possível efeito colateral na área odontológica, de característica irreversível, deve ser dado ao fabricante, para que averigüe e/ou reformule tal medicamento, sem contudo modificar sua principal finalidade.

Atualmente a criança é exposta a muitas fontes de flúor, além da água, principalmente devido ao uso de dentifrícios fluoretados e ao consumo de suplementos dietéticos, fórmulas infantis e alimentos e bebidas manufaturados, além da existência do "efeito halo" $69,88,117,148,168$. 
Além do mais, crianças com problemas de saúde crônicos são considerados de alto risco à cárie. A higiene bucal diária pode ser difícil de ser realizada, e do mesmo modo, pode ser completamente negligenciada. Um dos problemas mais complicados para lidar é a supercompensação que as crianças com problemas de saúde naturalmente experimentam dos pais, amigos e parentes. Durante sua permanência no hospital, assim como em casa, o consumo de açúcares, doces, refrigerantes, etc., tende a aumentar ${ }^{41}$. Elas têm, freqüentemente, uma necessidade especial de atenção profissional, precisando de cuidados preventivos e, assim, são freqüentemente expostas à fluorterapia ${ }^{144,145,157,171}$, às vezes de forma equivocada, com o uso de suplementos fluoretados, aplicações tópicas profissionais e práticas de bochechos com soluções fluoretadas. Todos os aspectos preventivos são extremamente importantes para as crianças com problemas de saúde crônicos, pois a condição bucal pode pôr em risco sua vida, como sendo um foco de infecção, e considerando sua própria condição sistêmica frente a um tratamento mais invasivo ${ }^{76}$. Evita-se o tratamento odontológico curativo por ser mais complexo e difícil, pela maior gravidade da maioria dos casos, pela falta de cooperação da criança e por sua debilidade orgânica ${ }^{53,76,91 .}$

Mesmo que crianças com dentes hipomineralizados, secreção salivar reduzida, dieta cariogênica e/ou função muscular prejudicada, por exemplo, possam necessitar de um intensivo programa de fluoretos ${ }^{91}$, deve-se continuar promovendo o uso racional do flúor, sem excessos.

No momento da prescrição de terapia com flúor, os profissionais, sejam eles médicos, dentistas ou farmacêuticos, devem ter conhecimento da exposição total do 
Discussão

paciente ao flúor, dos riscos e benefícios, bem como dos fatores que podem influenciar a sua absorção e aumentar a incidência e a gravidade da fluorose $\mathrm{e}^{10,117}$.

Com certa pretensão, permite-se pensar até mesmo que essas crianças são mais suscetíveis à fluorose que crianças saudáveis, quando em adicional se considera que podem consumir mais produtos à base de soja ou outros cereais e, apresentar significativas alterações metabólicas, que influenciam os efeitos tóxicos do flúor ${ }^{24,169}$.

SZPUNAR; BURT ${ }^{161}$ (1992) citaram que a absorção do flúor pode ser influenciada pela condição ácido-base do indivíduo e pela presença de doenças crônicas, como JUNCOS; DONADIO ${ }^{90}$ já relatavam em 1972 que o flúor poderia ser retido e causar fluorose, especialmente em pacientes com insuficiência renal, provavelmente relacionado à diminuição da função renal, à exposição elevada ao flúor da água, e à polidipsia secundária à poliúria.

CURY $^{30}$ (2001) comentou que a gravidade da fluorose pode ser acentuada por uma série de fatores conhecidos e outros ainda em avaliação. Citou entre eles, o jejum, os distúrbios metabólicos e a desnutrição. Tendo em vista que o flúor é absorvido também no estômago, a presença e o tipo de alimento afetam a absorção. Assim, se o flúor for ingerido em jejum, haverá $100 \%$ de absorção; se ingerido logo após o café da manhã ou após o almoço, a quantidade respectivamente absorvida será reduzida de 20 a $40 \%$. Quanto aos distúrbios metabólicos, se durante a excreção o pH estiver ácido, o flúor será reabsorvido nos túbulos renais e voltará para o sangue. A criança que não tem uma dieta mista e ingere basicamente leite por 2-3 anos, tem um pH urinário mais baixo devido ao catabolismo de proteínas. 
Discussão

Sendo a mamadeira preparada com leite em pó dissolvido com água fluoretada, haverá um agravamento da fluorose. O fator da desnutrição ainda não está estabelecido, mas como casos graves de desnutrição levam a defeitos de formação do esmalte, estes seriam agravados na presença de flúor.

A fluorose é um tema sobre o qual as pessoas estão se preocupando em muitos países ${ }^{143}$, e se no passado era preferível tê-la a ter cárie, no presente procura-se trabalhar com riscos mínimos de indução desta alteração irreversível no esmalte ${ }^{123}$. Havendo a redução da cárie, passa a haver um questionamento natural se não seria possível também conviver sem fluorose.

O momento é de crescente sensibilidade estética, e as pessoas podem estar mais atentas até mesmo às formas mais leves de fluorose que previamente se poderia imaginar ${ }^{117}$. Questões relacionadas à aparência dos dentes têm sido bastante enfatizadas. $\mathrm{O}$ risco é que este problema seja percebido pelas pessoas como uma conseqüência tóxica da ingestão de flúor e haja uma reação contra todas as formas de uso do mesmo, com conseqüências desastrosas para a saúde pública ${ }^{143}$.

A partir de uma perspectiva de saúde pública, o principal efeito negativo da fluorose é o envolvimento estético reconhecido, muitas vezes, mais pelo cirurgiãodentista que pelo paciente. Porém, sobretudo do ponto de vista biológico, a fluorose é um sinal da exposição excessiva, precoce e crônica ao flúor, a níveis capazes de afetar a amelogênese e provocar alterações na superfície do esmalte ${ }^{39,161}$. 
Discussão

Os riscos de fluorose podem ser evitados ou grandemente reduzidos se houver mais estudos sobre seus fatores de risco e a promoção do uso racional do flúor. 
7 CONCLUSÕES 


\section{CONCLUSÕES}

Após a análise dos resultados obtidos nas condições experimentais deste estudo, pôde-se constatar e concluir que:

7.1 - 99,12\% dos medicamentos apresentaram FT na sua composição, sendo: $79,80 \%$ (<0,1 ppmF); $12,30 \%$ (0,1 - 1,0 ppm F); 3,50\% (1,0 10,0 ppm F) e, 4,40\% (>10,0 ppm F) e, de todos os medicamentos estudados, apenas 26 eram polivitamínicos. Portanto, o flúor está sendo incorporado sem uma finalidade clara, na maioria dos medicamentos pediátricos.

$7.2-3,5 \%$ dos medicamentos que apresentaram FT numa concentração igual ou superior à faixa de segurança para uma criança de $12 \mathrm{~kg}$, continham na sua composição uma dose de FS equivalente a: 1,88 ppm F (Kalyamon ${ }^{\circledR}$ B-12); 3,58 ppm F (Calcigenol ${ }^{\circledR}$ B12); 5,98 ppm F (Calcigenol $^{\circledR}$ Irradiado); 37,15 ppm F (Epelin $\left.{ }^{\circledR}\right)$, com redução em relação ao $\mathrm{FT}$, respectivamente de: $98,07 \% ; 86,02 \% ; 88,46 \%$ e, $35,82 \%$. Portanto, os medicamentos polivitamínicos, embora contenham flúor na sua composição, por serem enriquecidos com sais minerais, mostraram uma redução mais acentuada da biodisponibilidade daquele elemento. 
7.3 - Nenhum medicamento apresentou o teor de FS igual ou superior àquele correspondente à dose "segura" de 0,05 a $0,07 \mathrm{mg} \mathrm{F} / \mathrm{kg}$ massa corporal/dia. O Epelin ${ }^{\circledR}$ foi o que mais se aproximou deste limite, com $0,046 \mathrm{mg} \mathrm{F} / \mathrm{kg}$ massa corporal/dia. Portanto, considerando-se apenas o teor de flúor potencialmente absorvível no estômago, e não aquele que o seria no intestino, somente o Epelin ${ }^{\circledR}$ apresentaria algum risco à fluorose desde que associado a outras fontes de flúor. Com relação aos polivitamínicos, embora com baixos valores de FS, não podem ser considerados isentos de risco à fluorose, pois desconhece-se o quanto de seu conteúdo de flúor seria absorvido no intestino, além das possíveis associações com outras fontes, que normalmente ocorrem. 
ANEXOS 


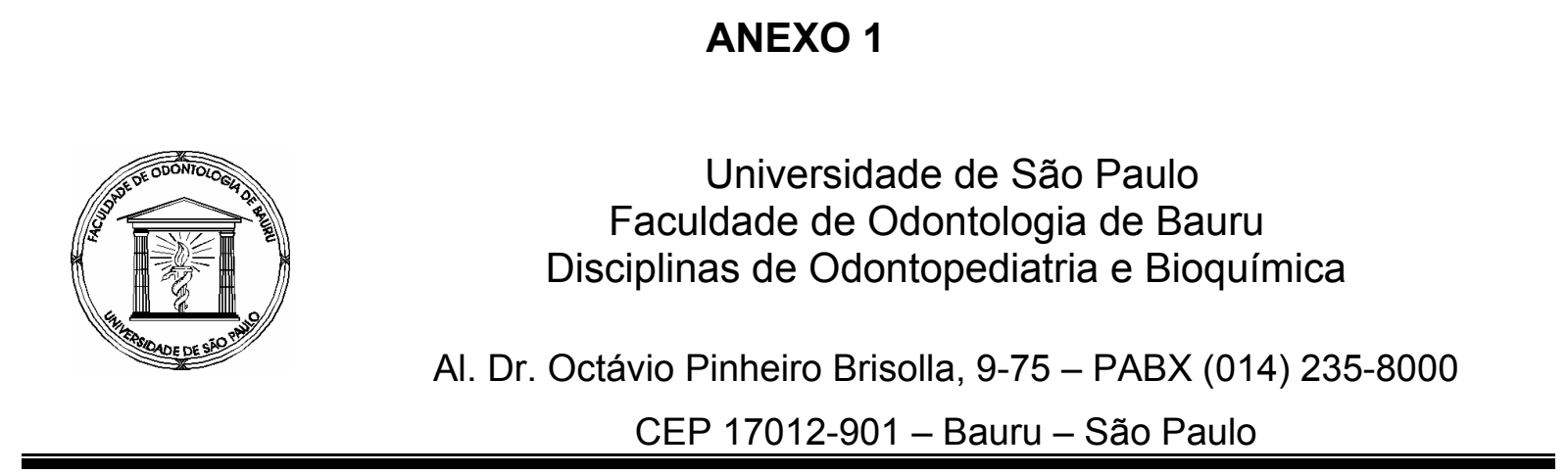

Pesquisa: Concentração de flúor em medicamentos pediátricos e risco de fluorose dentária

Pesquisadores: Andrea Anzai

Profa. Dra. Salete Moura Bonifácio da Silva

Especialidade:

- Quais são os problemas de saúde crônicos mais freqüentes em crianças?

- Quais são os medicamentos mais comumente prescritos nesses casos? 


\section{ANEXO 2}

\section{Teste de confiabilidade para análise de flúor total em medicamentos}

\begin{tabular}{|c|c|c|c|c|c|c|c|}
\hline ppm F & vol. $\mathrm{mL}$ & $\mu g F$ & $\log F$ & $\mathrm{mV}$ & Log F. Calc. & $\mu \mathrm{g} F$ calc. & \% variação \\
\hline 0,2 & 1 & 0,200 & $-0,698970$ & 110,3 & $-0,7282182$ & 0,187 & 6,51 \\
\hline 0,4 & 1 & 0,400 & $-0,397940$ & 94,1 & $-0,4400123$ & 0,363 & 9,23 \\
\hline 0,8 & 1 & 0,800 & $-0,096910$ & 76,2 & $-0,1215625$ & 0,756 & 5,52 \\
\hline 1,6 & 1 & 1,600 & 0,204120 & 58,5 & 0,1933291 & 1,561 & 2,45 \\
\hline 3,2 & 1 & 3,200 & 0,505150 & 40,1 & 0,5206741 & 3,316 & $-3,64$ \\
\hline 6,4 & 1 & \multirow[t]{2}{*}{6,400} & 0,806180 & 22,9 & \multirow[t]{2}{*}{0,8266704} & 6,709 & $-4,83$ \\
\hline intercepção & 1,2340726 & & inclinação & ,0177905 & & Rquad. & 0,996447 \\
\hline
\end{tabular}

\begin{tabular}{ccccccc} 
& $\mathbf{m V}$ & Log F. Calc. & $\boldsymbol{\mu g} \mathbf{F}$ calc. & $\boldsymbol{\mu g} \mathbf{F}$ esp. & $\mathbf{p p m} \mathbf{F}$ & $\%$ \\
Blanck & 136,5 & $-1,1943290$ & 0,064 & 0 & 0,06 & \#DIV/0! \\
Teste $\mathbf{0 , 4}$ & 92,6 & $-0,4133265$ & 0,386 & 0,40 & 0,39 & 3,48 \\
\multicolumn{2}{l}{ Volume das amostras } & $=1,0 \mathrm{~mL}$ & & & &
\end{tabular}

\section{ppm F}

Amostra

$\begin{array}{lccc}\text { 1A } & 145,2 & -1,3491062 & 0,045 \\ \text { 1B } & 145,9 & -1,3615595 & 0,043 \\ \text { 1C } & 147,1 & -1,3829081 & 0,041 \\ \text { 2A } & 135,5 & -1,1765385 & 0,067 \\ \text { 2B } & 136,7 & -1,1978870 & 0,063 \\ \text { 2C } & 134,7 & -1,1623061 & 0,069 \\ \text { 3A } & 148,1 & -1,4006986 & 0,040 \\ \text { 3B } & 147,8 & -1,3953615 & 0,040 \\ \text { 3C } & 148,2 & -1,4024777 & 0,040 \\ \text { 4A } & 144,7 & -1,3402110 & 0,046 \\ \text { 4B } & 145,9 & -1,3615595 & 0,043 \\ \text { 4C } & 146,8 & -1,3775710 & 0,042 \\ \text { 5A } & 142,6 & -1,3028509 & 0,050 \\ \text { 5B } & 143,7 & -1,3224205 & 0,048 \\ \text { 5C } & 142,6 & -1,3028509 & 0,050 \\ \text { 6A } & 118,6 & -0,8758792 & 0,133 \\ \text { 6B } & 119 & -0,8829954 & 0,131 \\ \text { 6C } & 119,1 & -0,8847745 & 0,130 \\ \text { 7A } & 130,4 & -1,0858070 & 0,082 \\ \text { 7B } & 131,3 & -1,1018184 & 0,079 \\ \text { 7C } & 130,9 & -1,0947022 & 0,080 \\ \text { 8A } & 135,1 & -1,1694223 & 0,068 \\ \text { 8B } & 136,6 & -1,1961080 & 0,064 \\ \text { 8C } & 136,9 & -1,2014451 & 0,063\end{array}$

Amostra

$9 \mathrm{~A}$

$9 B$

$9 \mathrm{C}$

$10 \mathrm{~A}$

10B

$10 \mathrm{C}$

$11 \mathrm{~A}$

11B

$11 \mathrm{C}$

$12 \mathrm{~A}$

12B

$12 \mathrm{C}$

$13 \mathrm{~A}$

13B

$13 \mathrm{C}$

$14 \mathrm{~A}$

14B

$14 \mathrm{C}$

$15 \mathrm{~A}$

15B

$15 \mathrm{C}$ ppm F

mV Log F. Calc. $\mu g$ F calc.

$151,8 \quad-1,4665234 \quad 0,034$

$153,3 \quad-1,4932091 \quad 0,032$

$152,9 \quad-1,4860930 \quad 0,033$

$150,8 \quad-1,4487329 \quad 0,036$

$151,2 \quad-1,4558491 \quad 0,035$

$152,2 \quad-1,4736396 \quad 0,034$

$151,3 \quad-1,4576282 \quad 0,035$

$153,7 \quad-1,5003253 \quad 0,032$

$154,2 \quad-1,5092206 \quad 0,031$

$148,8 \quad-1,4131520 \quad 0,039$

$\begin{array}{lll}152,8 & -1,4843139 & 0,033\end{array}$

$152,6 \quad-1,4807558 \quad 0,033$

$\begin{array}{lll}147,6 & -1,3918034 & 0,041\end{array}$

$148,7 \quad-1,4113729 \quad 0,039$

$148 \quad-1,3989196 \quad 0,040$

$148,6 \quad-1,4095939 \quad 0,039$

$148,6 \quad-1,4095939 \quad 0,039$

$149,5 \quad-1,4256053 \quad 0,038$

$152,8 \quad-1,4843139 \quad 0,033$

$153,5 \quad-1,4967672 \quad 0,032$

$152 \quad-1,4700815 \quad 0,034$ 


\section{ANEXO 3}

Estimativa do consumo diário de $\mathrm{F}$ a partir dos valores obtidos de FT

\begin{tabular}{|c|c|c|c|c|}
\hline \multirow[b]{2}{*}{ Medicamento } & \multicolumn{4}{|c|}{ Consumo diário } \\
\hline & $\mathrm{mL}^{*}$ & {$[\mathrm{FT}]^{\dagger}$} & Ingestão Total $^{\ddagger}$ & mg F/kg de massa ${ }^{\S}$ \\
\hline Kalyamon $^{\circledR} \mathrm{B}-12$ & 30 & 0,09780 & 2,934 & 0,244 \\
\hline Epelin $^{\circledR}$ & 15 & 0,05789 & 0,868 & 0,072 \\
\hline Calcigenol $^{\circledR}$ Irradiado & 20 & 0,05183 & 1,036 & 0,086 \\
\hline Calcigenol ${ }^{\circledR}$ Composto B12 & 30 & 0,02562 & 0,768 & 0,064 \\
\hline Hantina $^{\circledR}$ & 20 & 0,01625 & 0,325 & 0,027 \\
\hline Pipurol $^{\circledR}$ & 12 & 0,00711 & 0,085 & 0,007 \\
\hline Neutrofer ${ }^{\circledR} 250 \mathrm{mg} / \mathrm{mL}$ & 1 & 0,00516 & 0,005 & 0,000 \\
\hline Kaomagma $^{\circledR}$ & 10 & 0,00308 & 0,030 & 0,002 \\
\hline Nutri-Ped $^{\circledR}$ & 5 & 0,0019 & 0,009 & 0,000 \\
\hline Nonavit & 5 & 0,00079 & 0,003 & 0,000 \\
\hline Clavulin BD ${ }^{\circledR} 400 \mathrm{mg}$ & 5 & 0,00053 & 0,002 & 0,000 \\
\hline
\end{tabular}

* Posologia do medicamento recomendada para criança com $12 \mathrm{~kg}$

$\dagger 1 \mathrm{ppm}=1 \mu \mathrm{g} / \mathrm{mL}=0,001 \mathrm{mg} / \mathrm{mL}$

${ }^{\ddagger} \mathrm{mL}$. [FT] = Ingestão total $(\mathrm{mg} / \mathrm{mL})$

$\S$ Quantidade diária de FT ingerida para efeito de comparação com a dose "segura" (0,05 a 0,07 mg F / kg massa corporal / dia)

Observação: Todos os demais medicamentos que não constam nesta estimativa apresentaram resultados de $0,000 \mathrm{mg} \mathrm{F} / \mathrm{kg}$ massa corporal / dia. 


\section{ANEXO 4}

\section{Curva de calibração para análise FS em medicamentos}

\begin{tabular}{|c|c|c|c|c|c|c|c|c|}
\hline & ppm F & vol. mL & $\mu g F$ & $\log F$ & $\mathrm{mV}$ & \multicolumn{3}{|c|}{ Log F. Calc. $\mu$ g F calc. \% variação } \\
\hline & 0,4 & 0,5 & 0,200 & $-0,698970$ & 130,6 & $-0,6896130$ & 0,204 & $-2,18$ \\
\hline & 0,8 & 0,5 & 0,400 & $-0,397940$ & 115 & $-0,4031766$ & 0,395 & 1,20 \\
\hline & 1,6 & 0,5 & 0,800 & $-0,096910$ & 98,9 & $-0,1075596$ & 0,781 & 2,42 \\
\hline & 3,2 & 0,5 & 1,600 & 0,204120 & 81,9 & 0,2045827 & 1,602 & $-0,11$ \\
\hline & 6,4 & 0,5 & 3,200 & 0,505150 & 65,2 & 0,5112165 & 3,245 & $-1,41$ \\
\hline & intercepção & 1,7083737 & & inclinação & $-0,0183613$ & & Rquad. & 0,999707 \\
\hline & $\mathrm{mV}$ & Log F. Calc. & 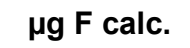 & $\mu g$ F esp. & ppm F & $\%$ & & \\
\hline Blanck & 166,5 & $-1,3487840$ & 0,045 & 0 & 0,04 & & & \\
\hline teste1, 6 & 98,6 & $-0,1020512$ & 0,791 & 0,80 & 0,79 & & & \\
\hline Amostras & & & $\begin{array}{l}\text { em } 1 \mathrm{~mL} \text { de } \\
\text { sobrenadant }\end{array}$ & $\begin{array}{l}\text { Vol total do } \\
\text { sobrenadante }\end{array}$ & $\begin{array}{c}\text { em } 3 \mathrm{~mL} \text { de } \\
\text { amostra }\end{array}$ & & $\begin{array}{r}1 \mathrm{n} \\
\text { medic }\end{array}$ & $\begin{array}{l}\text { L de } \\
\text { amento }\end{array}$ \\
\hline diluídas 5X) & $\mathrm{mV}$ & Log F. Calc. & 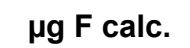 & $\mathrm{mL}$ & $\mu g$ total $F$ & & & $m \mathbf{F}$ \\
\hline Kalyamon & 131 & $-0,697$ & 0,201 & 5,600 & 1,13 & & & 88 \\
\hline Calc. Irrad. & 104,4 & $-0,209$ & 0,619 & 5,800 & 3,59 & & & 98 \\
\hline Calc. B12 & 116,1 & $-0,423$ & 0,377 & 5,700 & 2,15 & & & 58 \\
\hline Epelin & 61,2 & 0,585 & 3,843 & 5,800 & 22,29 & & & 15 \\
\hline
\end{tabular}




\section{REFERÊNCIAS}

\section{BIBLIOGRÁFICAS}




\section{REFERÊNCIAS BIBLIOGRÁFICAS}

1 ALMEIDA, B.S. de Concentração de flúor em alimentos sólidos e líquidos e sua relação com a fluorose. Bauru, 2002. 51 p. Monografia (Especialização) - Associação Paulista de Cirurgiões-Dentistas - Bauru.

2 AMERICAN ACADEMY OF PEDIATRICS. Council of Nutrition. Fluoride supplementation. Pediatrics, v.77, n. 5, p.758-61, May 1986.

3 ANGMAR-MÅNSSON, B.; ERICSSON, Y.; EKBERG, O. Plasma fluoride and enamel fluorosis. Calcif. Tissue Res., v.22, n.1, p.77-84, 1976.

4 ANGMAR-MÅNSSON, B.; WHITFORD, G.M. Plasma fluoride levels and enamel fluorosis in the rat. Caries Res., v.16, n.4, p.334-9, 1982.

5 ANGMAR-MÅNSSON, B.; WHITFORD, G.M. Enamel fluorosis related to plasma $\mathrm{F}$ levels in the rat. Caries Res., v.18, n.1, p.25-32, 1984.

6 ANGMAR-MÅNSSON, B.; WHITFORD, G.M. Single fluoride doses and enamel fluorosis in the rat. Caries Res., v.19, n.2, p.145-52, 1985.

7 ANGMAR-MÅNSSON, B.; LINDH, U.; WHITFORD, G.M. Enamel and dentin fluoride levels and fluorosis following single fluoride doses: A nuclear microprobe study. Caries Res., v.24, n.4, p.258-63, 1990.

8 ARMONIA, P.L. Riscos de fluorose dentária em crianças com três anos de idade que residem no município de São Paulo e utilizam creme dental fluorado. Rev. Inst. Ciênc. Saúde, v.16, n.1, p.13-9, jan./jun. 1998.

\footnotetext{
* Normas recomendadas para uso no âmbito da Universidade de São Paulo, com base no documento "Referências Bibliográficas: exemplos", emanado do Conselho Supervisor do Sistema Integrado de Bibliotecas da USP, em reunião de 20 de Setembro de 1990.
} 
9 ASSIS, G.F.; OLIVEIRA, D.T. Flúor em Odontologia: Aspectos básicos do mecanismo de ação. I - Mecanismos biológicos envolvidos na fluorose dentária. Bauru, Faculdade de Odontologia de Bauru Universidade de São Paulo, 1998.

10 ASSIS, G.F. et al. Mecanismos biológicos e influência de fatores ambientais na fluorose dentária e a participação do flúor na prevenção da cárie. Revisão de literatura. Rev. Fac. Odont. Bauru, v.7, n.3/4, p.63-70, jul./dez. 1999.

11 ASSOCIAÇÃO BRASILEIRA DE ODONTOLOGIA PREVENTIVA. Normas e produtos. Manipulando flúor com segurança. Parte 1: Unidades de Medida. J. ABOPREV, p.8, jul./ago./set. 1994.

12 BAELUM, $V$. et al. Daily dose of fluoride and dental fluorosis. Tandlaegebladet, p.452-6, 1987.

13 BÅRDSEN, A. "Risk periods" associated with the development of dental fluorosis in maxillary permanent central incisors: A meta-analysis. Acta odont. scand., v.57, n.5, p.247-56, Oct. 1999.

14 BASTOS, J.R.M. et al. Concentração de flúor em água mineral engarrafada e de fontes naturais das cidades de Lindóia, Águas de Lindóia e Serra Negra, Brasil. Rev. Fac. Odont. Univ. Passo Fundo, v.6, n.1, p.15-9, jan./jun. 2001.

15 BAWDEN, J.W. ed. Proceedings of the workshop: Changing patterns in systemic fluoride intake. J. dent. Res., v.71, n.5, p.1212-65, May 1992.

16 BELTRAN, E.D.; SZPUNAR, S.M. Fluoride in toothpastes for children: Suggestions for change. Pediatr. Dent., v.10, n.3, p.185-8, Sep. 1988.

17 BITTENCOURT, L.P. et al. Identificação de fatores de risco à fluorose - Relato de casos. J. Bras. Odontop. Odont. Bebê, v.1, n.4, p.17-23, out./dez. 1998.

18 BLACK,G.V.; McKAY, F.S. Mottled teeth - An endemic developmental 
imperfection of the teeth,therefore unknown in the literatura of dentistry. Dent. Cosmos, v.58, p.129-56, 1916.

19 BURT, B.A. The changing patterns of systemic fluoride intake. J. dent. Res., v.71, p.1228-37, May 1992. Special issue.

20 BUZALAF, M.A.R.; CURY, J.A.; WHITFORD, G.M. Fluoride exposures and dental fluorosis: A literature review. Rev. Fac. Odont. Bauru, v.9, n.1, p.110, jan./mar., 2001.

21 BUZALAF, M.A.R. et al. Fluoride content of infant formulas prepared with deionized, bottled mineral and fluoridated drinking water. J. dent. Child., v.68, n.1, p.37-41, Jan./Feb. 2001.

22 BUZALAF, M.A.R. et al. Correlation between plasma and nail fluoride concentrations in rats given different levels of fluoride in water. Fluoride, v.35, n.3, p.185-92, Aug. 2002.

23 BUZALAF, M.A.R. Fatores de risco para fluorose dentária e biomarcadores de exposição ao flúor. Bauru, 2002. Tese (LivreDocência) - Faculdade de Odontologia de Bauru - Universidade de São Paulo.

24 BUZALAF, M.A.R. et al. Fluoride content of infant foods in Brazil and risk of dental fluorosis. J. dent. Child., v.69, n.2, p.196-200, Mar./Apr. 2002.

25 CASTRO, G.B. et al. Estudo sobre a prevalência de fluorose em pacientes da FO-Gama Filho / RJ e fatores associados. Pesqui. Odontol. Bras., v.14, p.16, 2000. Suplemento (Anais da $17^{a}$. Reunião Anual da SBPqO), Abstract $n^{\circ} .1039$

26 CHEDID, S.; GUEDES-PINTO, A.C. Uso do flúor na clínica. In: GUEDESPINTO, A.C. Odontopediatria clínica. São Paulo, Artes Médicas, 1998. v.11, cap.4, p.43-57.

27 CLARK, D.C. ed. Report of the working group of the Canadian workshop on the evaluation of current recomendations concerning fluorides. Community Dent. oral Epidemiol., v.22, n. 3, p.140-3, June 1994. 
28 CLARK, D.C. Trends in prevalence of dental fluorosis in North America. Community Dent. oral Epidemiol., v.22, n. 3, p.148-52, June 1994.

29 CURY, J.A. Fluoretação da água: Benefícios, riscos e sugestões. Rev. Odont. Br. Central, SP, v.2, n.5, p.32-3, dez. 1992.

30 CURY, J.A. Uso do flúor e controle da cárie como doença. In: BARATIERI, L.N. et al. Odontologia restauradora - Fundamentos e possibilidades. São Paulo, Ed. Santos, 2001. Cap.2, p.32-68.

31 DABEKA, R.W.; McKENZIE, A.D. Microdiffusion and fluoride-specific electrode determination of fluoride in infant foods: Collaborative study. J. Assoc. Off. Anal. Chem., v.64, p.1021-6, 1981.

32 DEAN, H.T. Classification of mottled enamel diagnosis. J. Amer. dent. Ass., v.21, n.8, p.1421-6, Aug. 1934.

33 DEAN, H.T. Chronic endemic dental fluorosis (mottled enamel). J. Amer. med. Ass., v.107, p.1269-72, 1936.

34 DEAN, H.T. Endemic fluorosis and its relation to dental caries. Publ. Health Rep., v.53, p.1443-52, 1938.

35 DEAN, H.T. The investigations of physiological effects by the epidemiological method. In: MOULTON, F.R. ed. Fluoride and dental health. Washington, DC, 1942. p.23-31.

36 DEAN, H.T.; ARNOLD JR, F.A.; ELVOVE, E. Domestic water and dental caries: V. Additional studies of the relation of fluoride domestic waters to dental caries experience in 4425 white children, aged 12-14 years, of 13 cities in 4 states. Publ. Health Rep., v.57, p.1155-79, 1942.

37 DE LIEFDE, B.; HERBISON, G.P. The prevalence of developmental defects of enamel and dental caries in New Zealand children receiving differing fluoride supplementation, in 1982 and 1985. N. Z. Dent. J., v.85, n.379, p.2-8, 1989.

38 DENBESTEN, P.K.; THARIANI, H. Biological mechanisms of fluorosis and 
level and timing of systemic exposure to fluoride with respect to fluorosis. J. dent. Res., v.71, n.5, p.1238-43, May 1992.

39 DENBESTEN, P.K. Dental fluorosis: Its use as a biomaker. Adv. dent. Res., v.8, n.1, p.105-10, June 1994.

40 DENBESTEN, P.K. Biological mechanisms of dental fluorosis relevant to the use of fluoride supplements. Community Dent. oral Epidemiol., v.27, n.1, p.41-7, Feb. 1999.

41 DURWARD, C.; THOU, T. Dental caries and sugar-containing liquid medicines for children in New Zealand. N. Z. dent. J., v.93, n.414, p.124-9, Dec. 1997.

42 EAGER, J.M. Denti di Chiaie. Publ. Health Rep., v.16, p.2576, 1901.

43 EKSTRAND, J.; EHRNEBO, M. Influence of milk products of fluoride bioavailability in man. Eur. J. Clin. Pharmacol., v.16, p.211, 1979.

44 EKSTRAND, J. et al. Distribution of fluoride to human breast milk following intake of high doses of fluoride. Caries Res., v.18, n.1, p.93-5, 1984.

45 EKSTRAND, J. Fluoride intake in early infancy. J. Nutr., v.119, n.12 Suppl., p.1856-60, 1989.

46 ERICSSON, Y. The state of fluorine in milk and its absorption and retention when administered in milk. Investigations with radioactive fluorine. Acta odont. scand., v.16, p.51-77, 1958.

47 EVANS, R.W.; STAMM, J.W. An epidemiological estimate of the critical period during wich human maxillary central incisors are most susceptible to fluorosis. J. Publ. Health Dent., v.51, n.4, p.251-9, Fall 1991.

48 EVANS, R.W. An epidemiological assessment of the chronological distribution of dental fluorosis in human maxillary central incisors. J. dent. Res., v.72, n.5, p.883-90, May 1993.

49 EVANS, R.W.; DARVELL, B.W. Refining the estimate of the critical period for susceptibility to enamel fluorosis in humam maxillary central incisors. J. 
Publ. Health Dent., v.55, n.4, p.238-49, Fall 1995.

50 FANNING, E.A. A longitudinal study of tooth formation and root resorption. N. Z. Dent. J., v.57, p.202-17, 1961.

51 FARKAS, C.S.; FARKAS, E.J. Potential effect of food processing on the fluoride content of infant foods. Sci. Total Environ., v.2, p.399-405, 1974.

52 FEIGAL, R.J.; JENSEN, M.E.; MENSING, C.A. Dental caries potential of liquid medications. Pediatrics, v.68, n.3, p.416-9, Sep. 1981.

53 FEIGAL, R.J.; JENSEN, M.E. The cariogenic potential of liquid medications: A concern for the handicapped patient. Spec. Care Dentist., v.2, n.1, p.20-4, Jan./Feb. 1982.

54 FEJERSKOV, O. et al. Combined effect of systemic and topical fluoride treatments on human deciduous teeth - Case studies. Caries Res., v. 21, n. 5, p.452-9, 1987.

55 FEJERSKOV, O.; MANJI, F.; BAELUM, V. The nature and mechanisms of dental fluorosis in man. J. dent. Res., v.69 p.692-700, 1990. Special issue.

56 FEJERSKOV, O. et al. Posteruptive changes in human dental fluorosis - A histological and ultrastructural study. Proc. Finn. Dent. Soc., v.87, n.4, p.607-19, 1991.

57 FEJERSKOV, O. et al. Dental tissue effects of fluoride. Adv. dent. Res., v.8, n.1, p.15-31, June 1994.

58 FEJERSKOV, O. et al. Fluorose dentária: Um manual para profissionais da saúde. São Paulo, Ed. Santos, 1994. 122p.

59 FERNANDES, C.M.; TABCHOURY, C.M.; CURY, J.A. Fluoride concentration in infant foods and risk of dental fluorosis. J. dent. Res., v.80 (Spec. Iss.), p.224, 2001. (Abs 1505)

60 FERNANDES, L.M.A.G.; CURY, J.A. Avaliação metabólica do flúor pré-natal. Rev. Bras. Med., v.50, n.11, p.1546-54, nov. 1993.

61 FERREIRA, H.C.G. et al. Avaliação do teor de flúor na água de abastecimento 
público do município de Vitória - ES. Rev. Ass. Paul. Cirurg. Dent., v.53, n.6, p.455-9, nov./dez. 1999.

62 FERREIRA, R.A. Driblando a cárie. Rev. Ass. Paul. Cirurg. Dent., v.50, n.1, p.8-20, jan./fev. 1996.

63 FIGLIOLIA, S.L.C. et al. Conteúdo de flúor observado em refrescos preparados a partir de pós comerciais encontrados no comércio de Bauru - SP. In: JORNADA ODONTOLÓGICA DE BAURU, 13., Bauru, 2000. Anais. p.152

64 FOMON, S.J.; EKSTRAND, J. Fluoride intake by infants. J. Publ. Health Dent., v.59, n.4, p.229-34, Fall 1999.

65 FOMON, S.J.; EKSTRAND, J.; ZIEGLER, E.E. Fluoride intake and prevalence of dental fluorosis: Trends in fluoride intake with special attention to infants. J. Publ. Health Dent., v.60, n.3, p.131-9, Summer 2000.

66 FORRESTER, D.J.; SCHULZ JR, E.M. eds. International workshop on fluorides and dental caries reductions. Baltimore, MD: University of Maryland, 1974. In: LEVY, S.M.; GUHA-CHOWDHURY, N. Total fluoride intake and implications for dietary fluoride supplementation. J. Publ. Health Dent., v.59, n.4, p.211-23, Fall 1999.

67 GALAGAN, D.J.; LAMSON, G.G. Climate and endemic dental fluorosis. Publ. Health Rep.,, v.68, p.497, 1953.

68 GALAGAN, D.J.; VERMILLION, J.R. Determining optimum fluoride concentrations. Publ. Health Rep.,, v.72, p.491, 1957.

69 HARGREAVES, J.A. Water fluoridation and fluoride supplementation: Consideration for the future. J. dent. Res., v.69, p.765-70, Feb. 1990. Special issue.

70 HATTAB, F.N.; WEI, S.H.Y. Dietary sources of fluoride for infants and children in Hong Kong. Pediatr. Dent., v.10, n.1, p.13-8, Mar. 1988.

71 HEILMAN, J.R. et al. Fluoride concentrations of infant foods. J. Amer. dent. Ass., v.128, n.7, p.857-63, July 1997. 
72 HEILMAN, J.R. et al. Assessing fluoride levels of carbonated soft drinks. J. Amer. dent. Ass., v.130, n. 11, p.1593-9, Nov. 1999.

73 HEINTZE, S.D.; BASTOS, J.R.M. Avaliação do teor de flúor e pH em bebidas no mercado nacional. Rev. Ass. Paul. Cirurg. Dent., v.50, n.4, p.339-45, Jul./Ago. 1996.

74 HELLER, K.E.; EKLUND, S.A.; BURT, B.A. Dental caries and dental fluorosis at varying water fluoride concentrations. J. Publ. Health Dent., v.57, n.3, p.136-43, Summer 1997.

75 HILLER, K.A.; WILFART, G.; SCHMALZ, G. Developmental enamel defects in children with different fluoride supplementation - A follow-up study. Caries Res., v.32, n.6, p.4-5-11, 1998.

76 HOBSON, P. The treatment of medically handicapped children. Int. dent. J., v.30, n.1, p.6-13, 1980.

77 HOLLOWAY, P.J.; ELLWOOD, R.P. The prevalence, causes and cosmetic importance of dental fluorosis in the United Kingdom: A review. Community dent. Health, v.14, n.3, p.148-55, Sep. 1997.

78 HOLM, A.K.; ANDERSSON, R. Enamel mineralization disturbances in 12-yearold children with know early exposure to fluorides. Community Dent. oral Epidemiol., v.10, n.6, p.335-9, Nov./Dec. 1982.

79 HOROWITZ, A.M. Challenges of and strategies for changing prescribing practices of health care providers. J. Publ. Health Dent., v.59, n.4, p.27581, Fall 1999.

80 HOROWITZ, H.S. Commentary on and recommendations for the proper uses of fluoride. J. Publ. Health Dent., v.55, n.1, p.57-62, Winter 1995.

81 IRIGOYEN, D.E.; MOLINA, N.; LUENGAS, I. Prevalence and severity of dental fluorosis in a Mexican community with above-optimal fluoride concentration in drinking water. Community Dent. oral Epidemiol., v.23, n.4, p.243-5, Aug. 1995. 
82 ISHII, T.; SUCKLING, G. The appearance of tooth enamel in children ingesting water with a high fluoride content for a limited period during early tooth development. J. dent. Res., v.65, n.7, p.974-7, July 1986.

83 ISHII, T.; SUCKLING, G. The severity of dental fluorosis in children exposed to water with a high fluoride content for various periods of time. J. dent. Res., v.70, n.6, p.952-6, June 1991.

84 ISMAIL, A.I. et al. Prevalence of dental caries and dental fluorosis in students, 11-17 years of age in fluoridated and non-fluoridated cities in Quebec. Caries Res., v.24, n, 4, p.290-7, 1990.

85 ISMAIL, A.I. Fluoride supplements: Current effectiveness, side effects, and recommendations. Community Dent. oral Health, v.22, n.3, p.164-72, June, 1994.

86 ISMAIL, A.I.; BANDEKAR, R.R. Fluoride supplements and fluorosis: A metaanalysis. Community Dent. oral Health, v.27, n.1, p.48-56, Feb. 1999.

87 JACKSON, R.D. et al. Dental fluorosis and caries prevalence in children residing in communities with different levels of fluoride in the water. J. Publ. Health Dent., v.55, n.2, p.79-84, Spring 1995.

88 JACKSON, R.D. et al. The fluoride content of foods and beverages from negligibly and optimally fluoridated communities. Community Dent. oral Epidemiol., v.30, n.5, p.382-91, Oct. 2002.

89 JOHNSON JR., J.; BAWDEN, J.W. The fluoride content of infant formulas available in 1985. Pediatr. Dent., v.9, n.1, p.33-7, Mar. 1987.

90 JUNCOS, L.I.; DONADIO, J.V. Renal failure and fluorosis. J. Amer. med. Ass., v.222, n.7, p.783-5, Nov. 1972.

91 KOCK, G. et al. Crianças com comprometimento da saúde. In:

Odontopediatria: Uma abordagem clínica. 2.ed. São Paulo, Ed. Santos, 1995. Cap. 18, p.328-48.

92 KUMAR, J.V. et al. Trends in dental fluorosis and dental caries prevalences in 
Newburgh and Kingston, NY. Am. J. Public Health, v.79, n.5, p.565-9, May 1989.

93 LALUMANDIER, J.A.; GARY ROZIER, R. The prevalence and risk factors of fluorosis among patients in a pediatric dental practice. Pediatr. Dent., v.17, n.1, p.19-25, Jan./Feb. 1995.

94 LARA, V.S.; GRANJEIRO, J.M. Flúor em Odontologia: Aspectos básicos do mecanismo de ação. IV - Fatores que afetam a incidência e a gravidade da fluorose dentária. Bauru, Faculdade de Odontologia de Bauru - Universidade de São Paulo, 1998.

95 LARSEN, M.J. et al. Dental fluorosis in the primary and the permanent dentition in fluoridated areas with consumption of either powdered milk or natural cow's milk. J. dent. Res., v.67, n.5, p.822-5, May 1988.

96 LATIFAH, R.; RAZAK, I.A. Fluoride levels in infant formulas. J. Pedod., v.13, n.4, p.323-7, Summer 1989.

97 LEVY, S.M. A review of fluoride intake from fluoride dentifrice. J. dent. Child., v.60, n.2, p.115-24, Mar./Apr. 1993.

98 LEVY, S.M. Review of fluoride exposures and ingestion. Community Dent. oral Epidemiol., v.22, n.3, p.173-80, June 1994.

99 LEVY, S.M.; KIRITSY, M.C.; WARREN, J.J. Sources of fluoride intake in children. J. Publ. Health Dent., v.55, n.1, p.39-52, Winter 1995.

100 LEVY, S.M. et al. Infants' fluoride intake from drinking water alone, and from water added to formula, beverages, and food. J. dent. Res., v.74, n.7, p.1399-1407, July 1995.

101 LEVY, S.M.; GUHA-CHOWDHURY, N. Total fluoride intake and implications for dietary fluoride supplementation. J. Publ. Health Dent., v.59, n.4, p.211-23, Fall 1999.

102 LEWIS, D.W.; BANTING, D.W. Water fluoridation: Current effectiveness and dental fluorosis. Community Dent. oral Epidemiol., v.22, n. 3, p.153-8, 
June 1994.

103 LIMA, Y.B.O.; CURY, J.A. Ingestão de flúor por crianças pela água e dentifrício. Rev. Saúde Publ., v.35, n.6, p.576-81, dez. 2001.

104 MANJI, F.; BAELUM, V.; FEJERSKOV, O. Fluoride, altitude and dental fluorosis. Caries Res., v.20, n.5, p.473-80, 1986.

105 MARQUES, R.M. et al. Crescimento e desenvolvimento pubertário em crianças e adolescentes brasileiros. II Altura e peso. São Paulo, Editora Brasileira de Ciências, 1982.

106 MASCARENHAS, A.K. Risk factors for dental fluorosis: A review of the recent literature. Pediatr. Dent., v.22, n.4, p.269-77, July/Aug. 2000.

107 McCLURE, F.J. Ingestion of fluoride and dental caries, quantitative relations based on food and water requirements of children 1 to 12 years old. Am. J. Dis. Child., v.66, p.362-9, 1943.

108 McCLURE, F.J. Water fluoridation. The search and the victory. Washington, DC: US Government Printing Office, 1970. In: BUZALAF, M.A.R. Fatores de risco para fluorose dentária e biomarcadores de exposição ao flúor. Bauru, 2002. Tese (Livre-Docência) - Faculdade de Odontologia de Bauru - Universidade de São Paulo.

109 McKAY, F.S. Mottled enamel: The prevention of its further production through a chance of water supply at Oakley, IDA. J. Amer. dent. Ass., v.20, n.7, p.1137-49, July 1933.

110 McKNIGHT-HANES, M.C. et al. Fluoride content of infant formulas: Soy-based formulas as a potential factor in dental fluorosis. Pediatr. Dent., v.10, n.3, p.189-94, Sep. 1988.

111 MESSER, H.H.; NOPAKUM, J.; RUDNEY, J.D. Influence of pH on intestinal fluoride transport in vitro. J. dent. Assoc. Thai., v.39, n.6, p.226-32, Nov./Dec. 1989.

112 MESSER, H.H.; OPHAUG, R.H. Influence of gastric acidity on fluoride 
absorption in rats. J. dent. Res., v.72, n.3, p.619-22, Mar. 1993.

113 MONSOUR, P.A.; KRUGER, B.J.; SMID, J.R. Effects of a single intravenous dose of sodium fluoride on plasma electrolytes and metabolities in rats, rabbits, and cockerels. J. dent. Res., v.64, n.11, p.1281-5, Nov. 1985.

114 MURRAY, J.J. Presença e metabolismo dos fluoretos. In: O uso correto de fluoretos na saúde pública. São Paulo, Ed. Santos, 1992. Cap.1, p.3-32.

115 NARVAI, P.C. et al. Uso de produtos fluorados conforme o risco de cárie dentária: Uma revisão crítica. Rev. Ass. Paul. Cirurg. Dent., v.56, n.2, p.101-7, mar./abr. 2002.

116 NATIONAL CENTER FOR HEALTH STATISTICS in colaboration with the NATIONAL CENTER FOR CHRONIC DISEASE PREVENTION AND HEALTH PROMOTION . 2000. Disponível na internet. http://www.cdc.gov/growthcharts

117 NEWBRUN, E. Current regulations and recommendations concerning water fluoridation, fluoride supplements, and topical fluoride agents. J. dent. Res., v.71, n.5, p.1255-65, May 1992.

118 NEWBRUN, E. The case for reducing the current council on dental therapeutics fluoride supplementation schedule. J. Publ. Health Dent., v.59, n.4, p.263-8, Fall 1999.

119 NIELSEN, H.G.; RAVN, J.J. A radiographic study of mineralization of permanent teeth in a group of children aged 3-7 years. Scand. J. dent. Res., v.84, n.109-18, 1976.

120 NOLLA, C.M. The development of the permanent teeth. J. dent. Child., v.27, n.4, p.254-66, 1960.

121 NOPAKUN, J.; MESSER, H.H.; VOLLER, V. Fluoride absorption from the gastrointestinal tract of rats. J. Nutr., v.119, p.1411-7, 1989.

122 NOURJAH, P.; HOROWITZ, A.M.; WAGENER, D.K. Factors associated with 
the use of fluoride supplements and fluoride dentifrices by infant and toddlers. J. Publ. Health Dent., v.54, n.1, p.47-54, Winter 1994.

123 OLIVEIRA, A.C.B. de; AMARAL, C.R.F.L.; PEREIRA, C.R.S. Fluorose dentária: Uma revisão bibliográfica. Rev. ABO Nac., v.8, n.2, p.92-7, abr./maio, 2000.

124 OPHAUG, R.H.; SINGER, L.; HARLAND, B.F. Dietary fluoride intake of 6month and 2-year-old children in four dietary regions of the United States. Am. J. Clin. Nutr., v.42, p.701-7, 1985.

125 OSUJI, O.O. et al. Risk factors for dental fluorosis in a fluoridated community. J. dent. Res., v.67, n.12, p.1488-92, Dec. 1998.

126 Padrão de referência do NCHS Peter V.V., M.D.H., Terence A. Drizd, M.S.P.H., And Clifford L. Johnson, M.S.P.H., Division of Health Examination Statistics; Robert, B. Reed, PhD., Professor of Biostatistics, Harvard University; and Alex F. Roche, PhD., MD., Senior Scientist, Fels Research Institute, Yellow Spring, Ohio. NCHS Growth Curves for Children Birth - 18 Years.

127 PAIVA, S.M.; CURY, J.A. Contribution of diet and fluoridated dentifrice to the risk of dental fluorosis. J. dent. Res., v.78 (Spec. Iss.), p.367, 1999. (Abs 2089)

128 PANG, D.T.Y.; PHILLIPS, C.L.; BAWDEN, J.W. Fluoride intake from beverage consumption in a sample of North Carolina children. J. dent. Res., v.71, n.7, p.1382-8, July 1992.

129 PAZINATTO, F.B. et al. Histórico da utilização do flúor na prevenção da cárie dentária. Bauru, 2001. 60 p. Monografia (Mestrado) - Faculdade de Odontologia de Bauru - Bauru.

130 PENDRYS, D.G.; KATZ, R.V. Risk of enamel fluorosis associated with fluoride supplementation, infant formula, and fluoride dentifrice use. Am. J. Epidemiol., v.130, p.1199-1208, 1989.

131 PENDRYS, D.G.; MORSE, D.E. Use of fluoride supplementation by children living in fluoridated communities. J. dent. Child., v.57, n.5, p.343-7, 
Sep./Oct. 1990.

132 PENDRYS, D.G.; STAMM, J.W. Relationship of total fluoride intake to beneficial effects and enamel fluorosis. J. dent. Res., v.69, p.529-38, Feb. 1990. Special issue.

133 PENDRYS, D.G. Risk of fluorosis in a fluoridated population. Implications for the dentist and hygienist. J. Amer. dent. Ass., v.126, n.12, p.1617-24, Dec. 1995.

134 PENDRYS, D.G.; KATZ, R.V.; MORSE, D.E. Risk factors of enamel fluorosis in a non-fluoridated population. Am. J. Epidemiol., v.143, p.808-15, 1996.

135 PIN, M.L.G. et al. Concentração de flúor no leite, sucos, refrigerantes e alimentos infantis. Pesqui. Odontol. Bras., v.14, p.136, 2000. Suplemento (Anais da $17^{a}$. Reunião Anual da SBPqO), Abstract $n^{\circ}$. B231

136 PRAZERES GONÇALVES, J.; KNUPP, R.R.S. Avaliação do conhecimento dos pediatras sobre saúde oral na primeira infância. J. Bras. Odontop. Odont. Bebê, v.3, n.16, p.495-9, nov./dez. 2000.

137 RIBEIRO, D.A. Estudo morfológico e estereológico ultraestrutural do ameloblasto na fase de maturação do esmalte de dentes incisivos de ratos submetidos à fluorose. Bauru, 2001. 120p. Dissertação (Mestrado) - Faculdade de Odontologia de Bauru - Universidade de São Paulo.

138 RICHARDS, A.; FEJERSKOV, O.; BAELUM, V. Enamel fluoride in relation to severity of human dental fluorosis. Adv. dent. Res., v.3, n.2, p.147-53, Sep. 1989.

139 RICHARDS, A. Nature and mechanisms of dental fluorosis in animals. J. dent. Res., v.69, p.701-5, Feb. 1990. Special issue.

140 RICHARDS, L.F. et al. Determining optimum fluoride levels for community water supplies in relation to temperature. J. Amer. dent. Ass., v.74, n.2, p.389, Feb. 1967. 
141 RIORDAN, P.J.; BANKS, J.A. Dental fluorosis and fluoride exposure in Western Australia. J. dent. Res., v.70, n.7, p.1022-8, July 1991.

142 RIORDAN, P.J. Dental fluorosis, dental caries and fluoride exposure among 7years-olds. Caries Res., v.27, n.1, p.71-7, 1993.

143 RIORDAN, P.J. Fluoride supplements for young children: An analysis of the literature focusing on benefits and risks. Community Dent. oral Epidemiol., v.27, n.1, p.72-83, Feb. 1999.

144 RIPA, L.W. A critique of topical fluoride methods (dentifrices, mouthrinses, operator-, and self-applied gels) in an era of decreased caries and increased fluorosis prevalence. J. Public Health Dent., v.51, n.1, p.23-41, Winter 1991.

145 ROBERTS, I.F.; ROBERTS, G.J. Relation between medicines sweetened with sucrose and dental disease. Brit. Med. J., v.2, n.6181, p.14-6, Jul 1979.

146 ROBERTS, G.J.; ROBERTS, I.F. Dental disease in chronically sick children. J. dent. Child., v.48, n.5, p.346-51, Sep./Oct. 1981.

147 ROBINSON, C.; KIRKHAM, J. The effect of fluoride on the developing mineralized tissues. J. dent. Res., v.69, p.685-91, Feb. 1990. Special issue.

148 ROJAS-SANCHES, F. et al. Fluoride intake from foods, beverages and dentifrice by young children in communities with negligibly and optimally fluoridated water: a pilot study. Community Dent. oral Epidemiol., v.27, n. 4, p.288-97, Aug. 1999.

149 RWENYONYI, C.M. et al. Altitude as a risk indicator of dental fluorosis in children residing in areas with 0.5 and $2.5 \mathrm{mg}$ fluoride per litre in drinking water. Caries Res., v.33, n.4, p.267-74, 1999.

150 SATO, H.K.; FORNAZIERO, C.C.; WALTER, L.R.F. Escovação dentária e o risco de fluorose em crianças. Semina, v.18, ed. Especial, p.7-14, fev. 1997. 
151 SECRETARIA DE ESTADO DE SAÚDE. Saúde Bucal. Recomendações sobre uso de produtos fluorados no âmbito do SUS/SP em função do risco de cárie dentária. 2000. Disponível na internet. http://www.saude.sp.gov.br/html/fr sbucal.htm

152 SELWITZ, R.H. et al. Dental caries and dental fluorosis among children who were lifetime residents of communities having either low or optimal levels of fluoride in drinking water. J. Public Health Dent., v.58, n.1, p.26-35, Spring 1998.

153 SILVA, M.; REYNOLDS, E.C. Fluoride content of infant formulae in Australia. Austr. dent. J., v.41, n.1, p.37-42, Feb. 1996.

154 SILVA, S.M.B.; SANTOS, C.F. Medicamentos pediátricos e risco de cárie Uma revisão. Rev. Fac. Odont. Bauru, v.2, n.4, p.15-21, out./dez. 1996.

155 SINGER, L.; OPHAUG, R.H. Determination of fluoride in foods. J. Agric. Food Chem., v.34, p.510-3, 1986.

156 SMITH, C.E.; NANCI, A.; DENBESTEN, P.K. Effects of chronic fluoride exposure on morphometric parameters defining the stages of amelogenesis and ameloblast modulation in rat incisor. Anat. Rec., v.237, n.2, p.243-58, Oct. 1993.

157 SOUZA, V.M.; OLIVEIRA, R.M. Suplementação de flúor: Verificação de conduta dos médicos. Rev. gaúcha Odont., v.45, n.3, p.137-9, mai./jun. 1997.

158 SZPUNAR, S.M. et al. Trends in the prevalence of dental fluorosis in the United States: a review. J. Public Health Dent., v.47, n.2, p.71-9, Spring 1987.

159 SZPUNAR, S.M.; BURT, B.A. Dental caries, fluorosis, and fluoride exposure in Michigan schoolchildren. J. dent. Res., v.67, n.5, p.802-6, May 1988.

160 SZPUNAR, S.M.; BURT, B.A. Fluoride exposure in Michigan schoolchildren. J. Public Health Dent., v.50, n.1, p.18-23, Winter 1990. 
161 SZPUNAR, S.M.; BURT, B.A. Evaluation of appropriate use of dietary fluoride supplements in the US. Community Dent. oral Epidemiol., v.20, n.3, p.148-54, June 1992.

162 TAVARES, P.G.; BASTOS, J.R.M. Concentração de flúor na água: Cárie, fluorose e teor de flúor urinário em escolares de Bauru - SP. Rev. Ass. Paul. Cirurg. Dent., v.53, n.5, p.407-15, set./out. 1999.

163 TAVES, D.R. Separation of fluoride by rapid diffusion using hexamethyldisiloxane. Talanta, v.15, p.969-74, 1968.

164 TAVES, D.R. Dietary fluoride intake of fluoride ashed (total fluoride) V. unashed (inorganic fluoride) analysis of individual foods. Brit. J. Nutr., v.49, p.295-301, 1983.

165 TOUMBA, K.J.; LEVY, S.; CURZON, M.E.J. The fluoride content of bottled drinking waters. Br. Dent. J., v.176, n.7, p.266-8, Apr. 1994.

166 TRAUTNER, K.; SIEBERT, G. An experimental study of bioavailability of fluoride from dietary sources in man. Arch. oral Biol., v.31, n.4, p.223-8, 1986.

167 TRENCH, L.A. et al. Sistemic fluoride suplementation in gestation and childhood in Bauru. J. dent. Res., v.80, n.4, p.1081, 2001. (Abs 657)

168 TURNER, S.D.; CHAN, J.T.; LI, E. Impact of imported beverages on fluoridated and nonfluoridated communities. Gen. Dent., v.46, n.2, p.190-3, Mar./Apr. 1998.

169 VAN WINKLE, S. et al. Water and formula fluoride concentrations: Significance for infants fed formula. Pediatr. Dent., v.17, n.4, p.305-10, Jul./Aug. 1995.

170 VILLENA, R.S.; BORGES, D.G.; CURY, J.A. Avaliação da concentração de flúor em águas minerais comercializadas no Brasil. Revista de Saúde Públi., v.30, n.6, p.512-8, dez. 1996.

171 VILLENA, R.S.; CURY, J.A. Flúor - Aplicação sistêmica. In: CORRÊA, M.S.N.P. Odontopediatria na 1a. Infância. São Paulo, Ed. Santos, 1999. 
cap.24, p.291-342.

172 VLACHOU, A.; DRUMMOND, B.K.; CURZON, M.E.J. Fluoride concentrations of infant foods and drinks in the United Kingdom. Caries Res., v.26, n.1, p.29-32, 1992.

173 WAGENER, D.K.; NOURJAH, P.; HOROWITZ, A.M. Trends in childhood use of dental care products containing fluoride: United States, 1983-1989. Advance data from Vital and Health Statistics. Hyattsville, MD: National Center for Health Statistics \#219; Nov. 20, 1992. In: LEVY, S.M.; GUHACHOWDHURY, N. Total fluoride intake and implications for dietary fluoride supplementation. J. Public Health Dent., v.59, n.4, p.211-23, Fall 1999.

174 WANG, N.J.; GROPEN, A.M.; OGAARD, B. Risk factors associated with fluorosis in a non-fluoridated population in Norway. Community Dent. oral Epidemiol., v.25, n.6, p.396-401, Dec. 1997.

175 WARREN, J.J.; KANELLIS, M.J.; LEVY, S.M. Fluorosis of the primary dentition: What does it mean for permanent teeth? J. Amer. dent. Ass., v.130, n.3, p.347-56, Mar. 1999.

176 WHITFORD, G.M.; PASHLEY, D.H. Fluoride absorption: The effect of gastric acidity. Calcif. Tissue Int., v.36, p.302-7, 1984.

177 WHITFORD, G.M.; ALLMAN, D.W.; SHAHED, A.R. Topical fluorides: Effects on physiological and biochemical processes. J. dent. Res., v.66, p.1072-8, 1987.

178 WHITFORD, G.M. The physiological and toxicological characteristics of fluoride. J. dent. Res., 69, Spec. Iss., p.539-49, 1990.

179 WHITFORD, G.M. Intake and metabolism of fluoride. Adv. dent. Res., v.8, n.1, p.5-14, June 1994.

180 WHITFORD, G.M. Some characteristics of fluoride analysis with the electrode. In: Myers, H.M. (Ed.), The metabolism and toxicity of fluoride. Monogr. Oral Sci., Basel, Karger, p.24-9, 1996. 
181 WHITFORD, G.M. Determinants and mechanisms of enamel fluorosis. Ciba Found. Symp., v. 205, p.226-45, 1997.

182 WHITFORD, G.M. Fluoride metabolism and excretion in children. J. Public Health Dent., v.59, n.4, p.224-8, Fall 1999.

183 WILLIAMS, J.E.; ZWEMER, J.D. Community water fluoride levels, and preschool diet patterns, and the occurrence of fluoride enamel opacities $\mathbf{J}$. Public Health Dent., v.50, n.4, p.276-81, Fall 1990.

184 WILLIAMS, J.L. Mottled enamel and other studies of normal and pathological conditions of this issue. J. dent. Res., v.5, p.117, 1993.

185 WOOLFOLK, M.W.; FAJA, B.W.; BAGRAMIAN, R.A. Relation of sources of systemic fluoride to prevalence of dental fluorosis. J. Public Health Dent., v.49, n.2, p.78-82, Spring 1989.

186 WORLD HEALTH ORGANIZATION (WHO). Fluorides and oral health. Report of WHO expert committee and oral health status and fluoride use. WHO Technical Report Series 846. Geneva, WHO, 1994. p.37.

187 WORLD HEALTH ORGANIZATION (WHO). Expert Committee on Oral Health Status and Fluoride Use. 2001. Disponível na internet. http://www.edoc.co.za/dentalnet/whofluoride.html 
ABSTRACT 


\section{ABSTRACT}

\section{Fluoride concentration in pediatric medicines and the risk of dental fluorosis}

Owing to the increasing incidence of dental fluorosis, all possible fluoride sources consumed by children in the risk age group should be evaluated. Children with chronic health problems make routine use of medicines. This study aimed at analyzing the presence of total fluoride (TF) in 114 liquid pediatric medicines, through Taves' HMDS-HCl facilitated diffusion method; evaluating the concentration of soluble fluoride in $\mathrm{HCl} 0.01 \mathrm{M}(\mathrm{SF})$, after acid hydrolisis, of those which presented TF superior to the "safe" intake rate from 0.05 to 0.07 $\mathrm{mg} \mathrm{F} / \mathrm{kg}$ body mass/day, for a 12-kg child, as a simulation of the fluoride that would be bioavailable for absorption in the stomach; and researching the medicines that could be considered as risk factors to dental fluorosis, adopting for comparison, the same fluoride intake rate. Starting from these experimental conditions, it could be verified that $99.12 \%$ of the medicines presented TF in their composition, with variations between 0.0 and $97.8 \mathrm{ppm}$ F. Amongst these, the medicines which revealed TF equal or superior to the intake rate for a $12-\mathrm{kg}$ child after, considering the medicine volume consumed daily were: Kalyamon ${ }^{\mathrm{TM}} \mathrm{B}-12$ (97.80 ppm F; 0.244 mg F/kg/day), Epelin ${ }^{\mathrm{TM}}$ (57.89 ppm F; 0.072 mg F/kg/day), Irradiated Calcigenol $^{\mathrm{TM}}\left(51.83\right.$ ppm F; 0.086 mg F/kg/day) and Combined Calcigenol ${ }^{\mathrm{TM}} \mathrm{B} 12$ (25.62 ppm $\mathrm{F} ; 0.064 \mathrm{mg} \mathrm{F} / \mathrm{kg} /$ day). They also presented values of SF of $1.88 \mathrm{ppm} \mathrm{F} ; 37.15 \mathrm{ppm} \mathrm{F} ; 5.98$ ppm F; and 3.58 ppm F, respectively, all inferior when compared to those of TF. No medicine presented a SF content equal or superior to that of the corresponding fluoride "safe" dose. Nevertheless, Epelin ${ }^{\mathrm{TM}}(0.046 \mathrm{mg} \mathrm{F} / \mathrm{kg} /$ day $)$ was close to that rate. It was concluded that fluoride was present without a clear purpose in most medicines. The three polivitaminic medicines showed a marked reduction of fluoride bioavailability in the stomach, for being enriched with mineral salts. Taking into account the gastric absorption, alone, Epelin ${ }^{\mathrm{TM}}$ could pose a risk to fluorosis when associated to other fluoride sources. However, caution is recommended regarding the other polivitaminics, for the rate of intestinal absorption is 
ignored, besides that it is not possible to control the associations with the other fluoride sources, which usually take place. 